Prepared in cooperation with the State of Hawai'i Commission on Water Resource Management

\title{
Low-Flow Characteristics of Streams in the Lahaina District, West Maui, Hawai'i
}

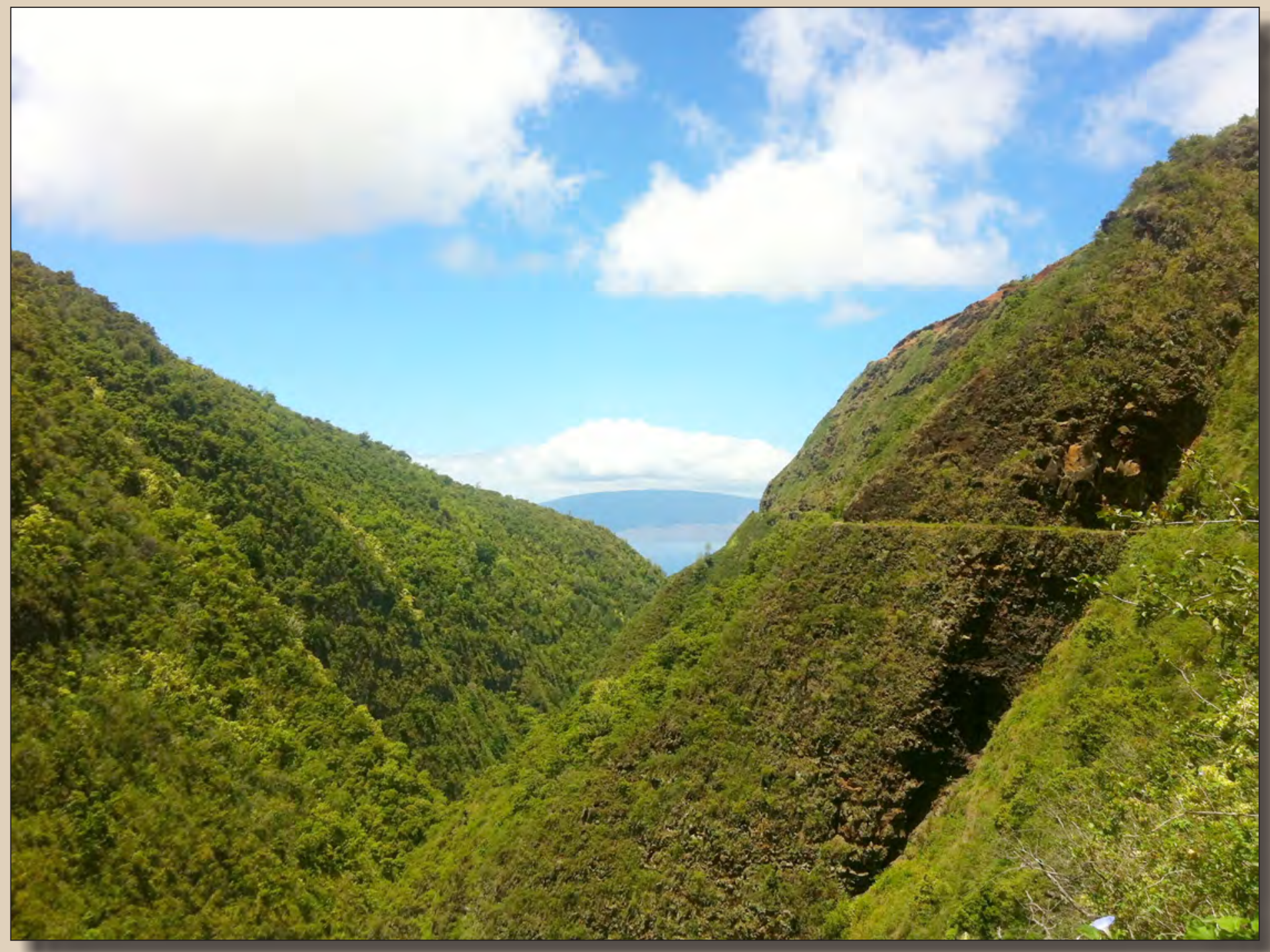

Scientific Investigations Report 2014-5087 
Cover photograph. Kahoma Stream valley, Maui, Hawai'i, with the island of Lāna'i in the distance. Photograph by Chui Ling Cheng. 


\section{Low-Flow Characteristics of Streams in the Lahaina District, West Maui, Hawai'i}

By Chui Ling Cheng

Prepared in cooperation with the State of Hawai'i Commission on Water Resource Management

Scientific Investigations Report 2014-5087 


\title{
U.S. Department of the Interior SALLY JEWELL, Secretary
}

\author{
U.S. Geological Survey \\ Suzette M. Kimball, Acting Director
}

\author{
U.S. Geological Survey, Reston, Virginia: 2014
}

For more information on the USGS - the Federal source for science about the Earth, its natural and living resources, natural hazards, and the environment, visit http://www.usgs.gov or call 1-888-ASK-USGS.

For an overview of USGS information products, including maps, imagery, and publications, visit http://www.usgs.gov/pubprod

To order this and other USGS information products, visit http://store.usgs.gov

Any use of trade, firm, or product names is for descriptive purposes only and does not imply endorsement by the U.S. Government.

Although this information product, for the most part, is in the public domain, it also may contain copyrighted materials as noted in the text. Permission to reproduce copyrighted items must be secured from the copyright owner.

Suggested citation:

Cheng, C.L., 2014, Low-flow characteristics of streams in the Lahaina District, West Maui, Hawai'i: U.S. Geological Survey Scientific Investigations Report 2014-5087, 58 p., http://dx.doi.org/10.3133/sir20145087.

ISSN: 2328-0328 (online) 


\section{Executive Summary}

In Hawai'i, the diversion of surface water during low-flow conditions greatly influences water availability for ecosystems, aquatic biota, and people. Existing diversion structures are capable of capturing a majority of the low flow in the streams, leaving some downstream reaches dry, which can adversely affect traditional Hawaiian practices, stream ecology, water quality, recreational activities, and aesthetics. Competition for limited water resources for offstream and instream uses has led to costly litigation over rights to the water between those currently diverting the water and those desiring sufficient flow in the stream for instream uses. Information on natural stream discharge during low-flow conditions is needed to effectively manage Hawaili's surfacewater resources for current and future uses. This report describes natural low-flow conditions for Honolua Stream and its tributary Pāpua Gulch, Honokahua Stream and its tributary Mokupe‘a Gulch, Kahana Stream, Honokōwai Stream and its tributaries Amalu and Kapāloa Streams, Wahikuli Gulch and its tributary Hāhākea Gulch, Kahoma Stream and its tributary Kanahā Stream, Kaua'ula Stream, Launiupoko Stream, Olowalu Stream, and Ukumehame Gulch in west Maui. The U.S. Geological Survey undertook the present investigation in cooperation with the State of Hawai'i Commission on Water Resource Management (CWRM).

The CWRM establishes instream-flow standards to protect the public interest in the stream with consideration of current and future water uses. The standards adopted for all streams in west Maui in October 1988 did not have quantitative flow values and allowed diversions existing at that time to continue operating. Quantitative instream-flow standards have not been established for the streams, and they are needed to effectively manage water resources for competing uses. Results of this study can be used to assist in the determination of technically defensible instreamflow standards for the study-area streams.

\section{Existing Surface-Water Diversions}

In the western part of west Maui, surface water is used for irrigating coffee and other food crops, raising livestock, and domestic water supply. During the study period 2012-13, Honokōwai, Kahoma, Kanahā, Kaua'ula, Launiupoko, and Olowalu Streams, and Ukumehame Gulch were diverted at the upper reaches; Honolua Stream was not diverted. Diversion intakes and estimated average amounts of diverted flow for these streams are summarized in table ES1. 
Table ES1. Major surface-water diversion intakes in operation during the study period (2012-13) and estimated amounts of surface water recently diverted in the study area, west Maui, Hawai'i.

$\left[\mathrm{ft}^{3} / \mathrm{s}\right.$, cubic feet per second; -, not applicable]

\begin{tabular}{lcc}
\hline \multicolumn{1}{c}{ Stream name } & $\begin{array}{c}\text { Altitude, in feet }{ }^{\mathrm{a}}, \text { of } \\
\text { diversion intake }^{\mathrm{b}}\end{array}$ & Estimated diverted flow, in $\mathbf{f t}^{3} / \mathbf{s}$ \\
\hline Honolua Stream & 800 & Not diverted \\
Honokōwai Stream & & $4.2^{\mathrm{c}}$ \\
$\quad$ Amalu Stream & 1,600 & - \\
$\quad 1,560$ & - \\
$\quad$ Kapāloa Stream & 1,920 & $0.27^{\mathrm{d}}$ \\
Kahoma Stream & 1,120 & $2.2^{\mathrm{e}}$ \\
$\quad$ Kanahā Stream & 1,540 & $7.0^{\mathrm{f}}$ \\
Kaua ${ }^{\mathrm{c} u l a}$ Stream & 1,230 & $0.58^{\mathrm{f}}$ \\
Launiupoko Stream & 520 & $4.4^{\mathrm{f}}$ \\
Olowalu Stream & 240 & No data \\
Ukumehame Gulch & & \\
\hline
\end{tabular}

${ }^{\text {a}}$ Altitude determined from topographic map.

${ }^{\mathrm{b}}$ Taro diversions not included.

cCombined flow estimate from both tributaries between 2002 and 2012 (Robert Vorfeld, Kā'anapali Land Management Corp., oral commun., 2013).

${ }^{\mathrm{d}}$ Estimate for 2012 from State of Hawai 'i Commission on Water Resource Management records.

eAverage for 2009 and 2010 from Maui Department of Water Supply records.

fAverage between 2007 and 2012 from State of Hawai ‘i Commission on Water Resource Management records.

\section{Water Availability}

Many of the streams in the study area (fig. ES1) flow perennially in the upper reaches (upstream from diversions) because of persistent groundwater discharge to the streams. Downstream from diversions in the lower reaches, the streams generally lose water. Under natural-flow conditions (no diversion of surface water), Honolua Stream is estimated to support mauka to makai (mountain to ocean) flow less than 80 percent of the time, and Honokōwai Stream supports mauka to makai flow less than 50 percent of the time. Kahoma Stream is estimated to flow continuously from the upper diversion intake to the confluence with Kanahā Stream at least 85 percent of the time and Kanahā Stream is estimated to flow to the confluence with Kahoma Stream at least 95 percent of the time. Downstream from the confluence of the two streams, the concrete-lined channel is estimated to flow to the ocean at least 95 percent of the time. Kaua'ula Stream, Olowalu Stream, and Ukumehame Gulch are estimated to support mauka to makai flow at least 95 percent of the time. Insufficient data were available to characterize the magnitude of seepage gains and losses in Launiupoko Stream. Measured seepage-loss rates ranged between 0.045 and 1.6 cubic feet per second per mile of stream reach. Seepage gains mostly occurred upstream from diversions and the measured seepage-gain 
rates generally ranged between 0.75 and 5.1 cubic feet per second per mile of stream reach. Pāpua Gulch, Honokahua Stream and its tributary Mokupe'a Gulch, Kahana Stream, and Wahikuli Gulch and its tributary Hāhākea Gulch are ephemeral streams, meaning they only flow in response to rainfall sufficient to cause runoff, and they are dry at least 50 percent of the time.

\section{Information Use and Research Needs}

Streamflow characteristics under low-flow conditions in the upper stream reaches coupled with seepage-run measurements downstream from surface-water diversions can provide natural water-availability information in the lower stream reaches and indicate whether the streams support mauka to makai flow. This information is useful for the determination of quantitative instream-flow standards that account for economic, cultural, ecologic, recreational, and aesthetic needs. Information on mauka to makai flow is important in evaluating the biological potential of a stream to support native stream fauna and whether decreasing or eliminating diversions is necessary to maintain adequate flow in the lower reaches.

Surface-water availability can be most accurately determined from longterm continuous-record streamflow-gaging stations. Additional seepagerun measurements on Honokōwai, Kanahā, Launiupoko, Kaua'ula, and Olowalu Streams during undiverted conditions can help determine the magnitude of seepage losses in the lower reaches and the occurrence of mauka to makai flow under natural-flow conditions. 


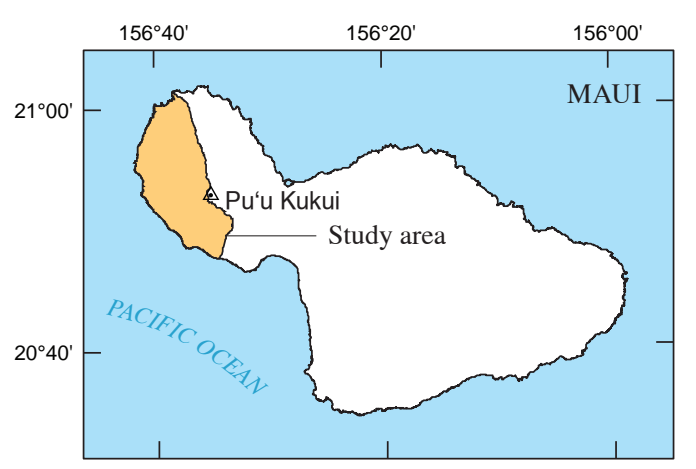

EXPLANATION

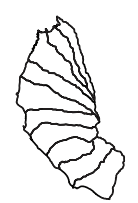

Study area and boundaries between stream areas (modified from Hawai'i Office of Planning, 2013)

\section{Surface-water diversion system -}

In operation during study period 2012-13

Surface-water diversion intake -

In operation during study period 2012-13

\section{Partial-record discharge-measurement site}

5.8 (2.0) Left number indicates natural median discharge, in cubic feet per second, during 1984-2013. Number in parentheses indicates natural discharge, in cubic feet per second, equaled or exceeded 95 percent of the time during 1984-2013.

* Values for Honokōwai Stream represent the total discharge at the confluence of Amalu and Kapāloa Streams

\section{Stream reaches under natural median-flow conditions}

\begin{tabular}{llr}
\hline Flowing reach observed without measurements \\
Gaining reach & Losing reach \\
Dry reach & Not surveyed
\end{tabular}

Base modified from U.S. Geological Survey digital data. Universal Transverse Mercator projection, zone 4, North American Datum 1983.

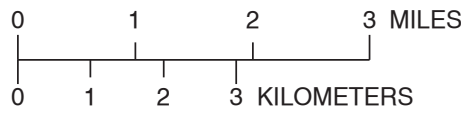

Figure ES1. Map showing low-flow duration discharges at partial-record sites and gaining and losing reaches under natural median-flow conditions in the study-area streams, west Maui, Hawai i i. 


\section{Contents}

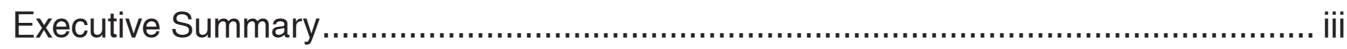

Existing Surface-Water Diversions ................................................................... ii

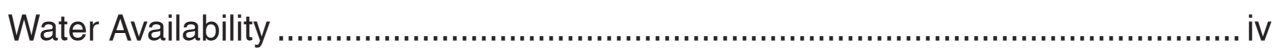

Information Use and Research Needs ...........................................................

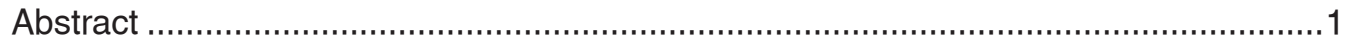

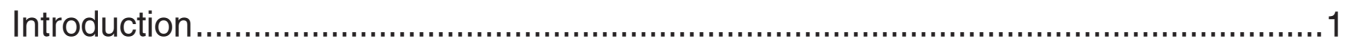

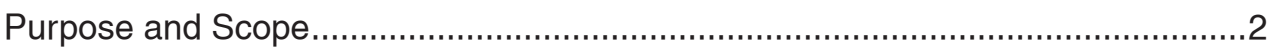

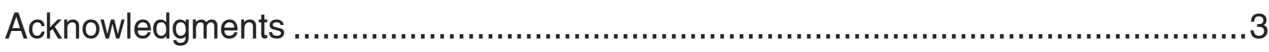

Description of the Study Area

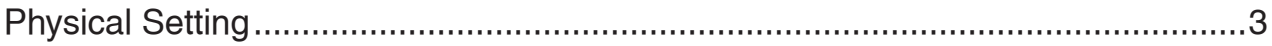

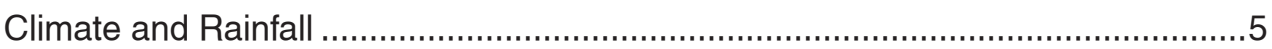

Surface-Water Diversions.......................................................................... 5

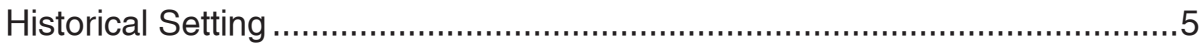

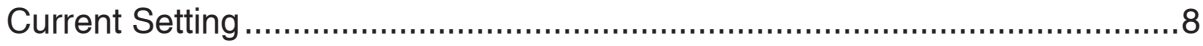

Historical Streamflow Data ....................................................................... 11

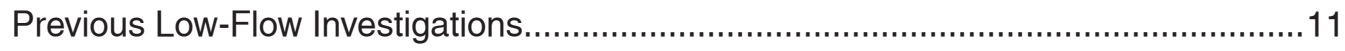

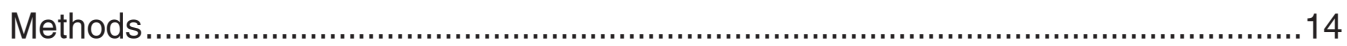

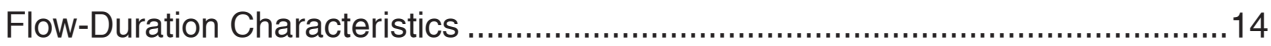

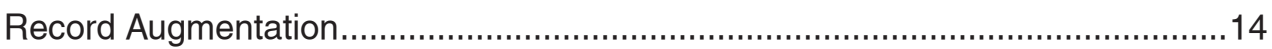

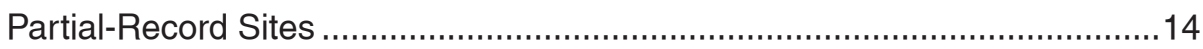

Index Stations and Selection of Base Period ...........................................17

Record-Augmentation Techniques ........................................................19

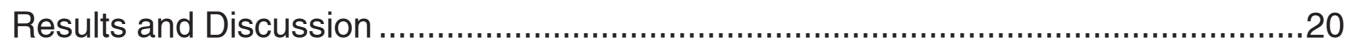

Natural Low-Flow Duration Discharges .............................................................20

Flow-Duration Discharges Estimated Using the Graphical Correlation

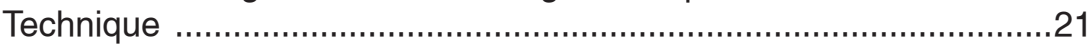

Flow-Duration Discharges Estimated Using the MOVE.1 Technique ............24

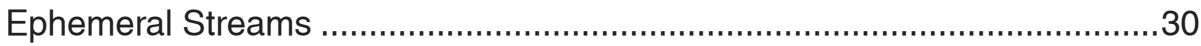

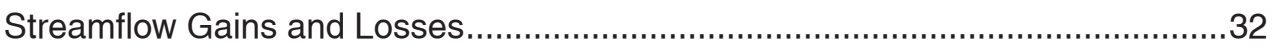

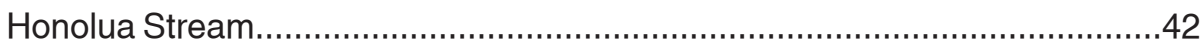

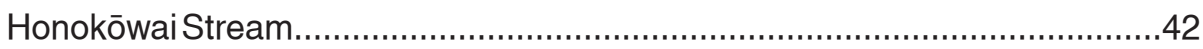

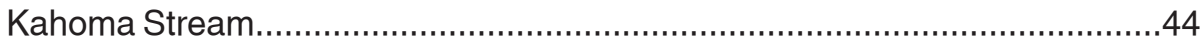

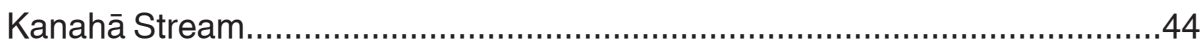

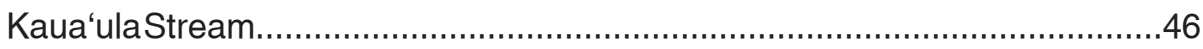

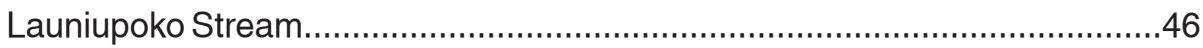

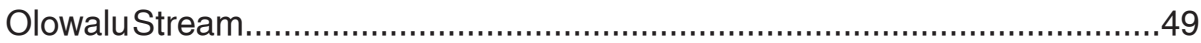

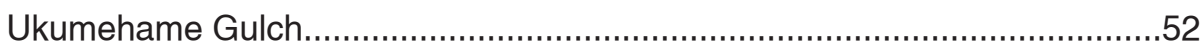

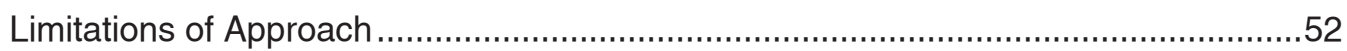

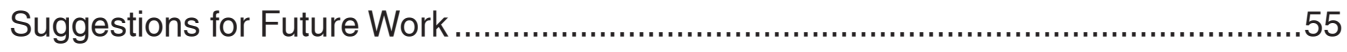

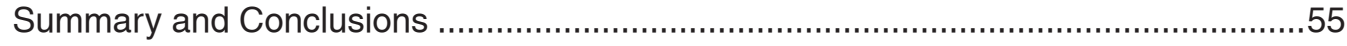

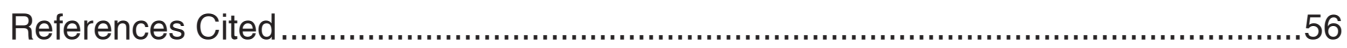




\section{Figures}

1. Map showing location of study area, partial-record sites in Lahaina District, and locations of active and inactive continuous-record streamflow-gaging stations in west Maui and Moloka'i, Hawai'i.......................4

2. Map of mean annual rainfall, west Maui, Hawai'i ..........................................6

3. Map showing locations of major diversion systems and associated intakes, and U.S. Geological Survey ditch-flow gaging stations in the study area, west Maui, Hawai'i

4. Photographs of select diversion intakes in the study area, west Maui, Hawai'i.

5. Photographs of study-area streams near the selected partial-record sites, west Maui, Hawai'i.

6. Plots showing flow-duration curves for total flow at index stations for base period 1984-2013

7. Plots showing relation between measured discharges at partial-record sites and concurrent daily mean discharges at index station 16620000 on Honokōhau Stream, Maui, Hawai'i.

8. Map of seepage-run measurement sites for Honolua Stream, west Maui, Hawai'i.

9. Map of seepage-run measurement sites for Honokōwai Stream, west Maui, Hawai'i

10. Photograph showing leakage from Honokōhau Ditch downstream from the diversion dam on Kapāloa Stream, Maui, Hawai'i, during the seepage run on July 25, 2012

11. Map of seepage-run measurement sites for Kahoma and Kanahā Streams, west Maui, Hawai' $\mathrm{i}$

12. Map of seepage-run measurement sites for Kaua'ula Stream, west Maui, Hawai'i.

13. Map of seepage-run measurement sites for Launiupoko Stream, west Maui, Hawai'i

14. Map of seepage-run measurement sites for Olowalu Stream, west Maui, Hawai'i.

15. Photograph showing leakage from Olowalu Ditch into Olowalu Stream, west Maui, Hawai'i, during the seepage run on February 13, 2013.

16. Map of seepage-run measurement sites for Ukumehame Gulch, west Maui, Hawai'i 


\section{Tables}

1. Selected flow-duration discharges computed based on complete water years during the period of record at inactive continuous-record streamflow-gaging stations in the study area, west Maui, Hawai'i

2. Miscellaneous discharge measurements made at the study-area streams during 1911-67, west Maui, Hawai'i

3. Location of partial-record measurement sites established on the study-area streams, west Maui, Hawai'i.

4. Selected flow-duration discharges for selected periods at index stations for partial-record sites established in the study area, west Maui, Hawai'i.......18

5. Summary of regression equations and selected regression statistics for partial-record sites in the study-area streams, west Maui, Hawai $i$

6. Selected natural-flow duration discharge estimates at partial-record sites in the study-area streams, west Maui, Hawai'i, for base period 1984-2013.

7. Measured discharges at partial-record site 205856156370801 on Honolua Stream and concurrent daily mean discharges at streamflowgaging station 16620000 on Honokōhau Stream, west Maui, Hawai'i

8. Measured discharges at partial-record site 205404156372401 on Kahoma Stream and concurrent daily mean discharges at streamflowgaging station 16620000 on Honokōhau Stream, west Maui, Hawai'i.....

9. Combined discharges measured at partial-record sites 205554156370701

on Amalu Stream and 205545156371601 on Kapāloa Stream, and concurrent daily mean discharges at streamflow-gaging station 16620000 on Honokōhau Stream, west Maui, Hawai'i

10. Measured discharges at partial-record site 205334156382201 on Kanahā Stream and concurrent daily mean discharges at streamflowgaging station 16400000 on Hālawa Stream, Moloka'i, Hawai'i

11. Measured discharges at partial-record site 205239156372101 on Kaua'ula Stream and concurrent daily mean discharges at streamflowgaging station 16620000 on Honokōhau Stream, west Maui, Hawai'i

12. Measured discharges at partial-record site 205117156365201 on Launiupoko Stream and partial-record site 16647000 on Ukumehame Gulch, west Maui, Hawai'i

13. Measured discharges at partial-record site 205000156355801 on Olowalu Stream and concurrent daily mean discharges at streamflowgaging station 16604500 on 'Tao Stream, west Maui, Hawai'i.....

14. Measured discharges at partial-record site 16647000 on Ukumehame Gulch and concurrent daily mean discharges at streamflow-gaging station 16604500 on 'lào Stream, west Maui, Hawai'i

15. Flow condition at partial-record sites on ephemeral streams and concurrent daily mean discharges at streamflow-gaging station 16620000 on Honokōhau Stream, west Maui, Hawai'i

16. Seepage-run discharge measurements conducted on study-area streams, west Maui, Hawai'i. 


\section{Conversion Factors}

\begin{tabular}{|c|c|c|}
\hline Multiply & By & To obtain \\
\hline \multicolumn{3}{|c|}{ Length } \\
\hline inch (in.) & 2.54 & centimeter $(\mathrm{cm})$ \\
\hline inch (in.) & 25.4 & millimeter (mm) \\
\hline foot $(\mathrm{ft})$ & 0.3048 & meter $(\mathrm{m})$ \\
\hline mile (mi) & 1.609 & kilometer $(\mathrm{km})$ \\
\hline \multicolumn{3}{|c|}{ Area } \\
\hline square mile $\left(\mathrm{mi}^{2}\right)$ & 2.590 & square kilometer $\left(\mathrm{km}^{2}\right)$ \\
\hline \multicolumn{3}{|c|}{ Volume } \\
\hline gallon (gal) & 0.003785 & cubic meter $\left(\mathrm{m}^{3}\right)$ \\
\hline million gallons (Mgal) & 3,785 & cubic meter $\left(\mathrm{m}^{3}\right)$ \\
\hline cubic foot $\left(\mathrm{ft}^{3}\right)$ & 0.02832 & cubic meter $\left(\mathrm{m}^{3}\right)$ \\
\hline \multicolumn{3}{|c|}{ Flow rate } \\
\hline cubic foot per second $\left(\mathrm{ft}^{3} / \mathrm{s}\right)$ & 0.64636 & million gallons per day (Mgal/d) \\
\hline gallon per day (gal/d) & 0.003785 & cubic meter per day $\left(\mathrm{m}^{3} / \mathrm{d}\right)$ \\
\hline million gallons per day (Mgal/d) & 0.04381 & cubic meter per second $\left(\mathrm{m}^{3} / \mathrm{s}\right)$ \\
\hline
\end{tabular}

Seepage rate in cubic feet per second per mile of stream reach $\left[\left(\mathrm{ft}^{3} / \mathrm{s}\right) / \mathrm{mi}\right]$ may be converted to cubic meter per second per kilometer of stream reach $\left[\left(\mathrm{m}^{3} / \mathrm{s}\right) \mathrm{km}\right]$ as follows:

$\mathrm{m}^{3} / \mathrm{s} / \mathrm{km}=0.0176 \times\left[\left(\mathrm{ft}^{3} / \mathrm{s}\right) / \mathrm{mi}\right]$

Vertical coordinate information is referenced relative to local mean sea level.

Horizontal coordinate information is referenced North American Datum of 1983 (NAD 83).

Altitude, as used in this report, refers to distance above the vertical datum.

\section{Acronyms}

\begin{tabular}{ll}
\hline Acronym & \multicolumn{1}{c}{ Meaning } \\
\hline CPMM & Commercial Properties of Maui Management, Inc. \\
CWRM & State of Hawai'i Commission on Water Resource Management \\
KLM & Kā‘anapali Land Management Corp. \\
MDWS & Maui County Department of Water Supply \\
ML\&P & Maui Land and Pineapple Company, Inc. \\
MOVE.1 & Maintenance of Variance Extension Type 1 \\
WML & West Maui Land Company, Inc. \\
USGS & U.S. Geological Survey \\
\hline
\end{tabular}




\title{
Low-Flow Characteristics of Streams in the Lahaina District, West Maui, Hawai'i
}

\author{
By Chui Ling Cheng
}

\section{Abstract}

The purpose of this study was to characterize streamflow availability under natural low-flow conditions for streams in the Lahaina District, west Maui, Hawai' $i$. The study-area streams included Honolua Stream and tributary Pāpua Gulch, Honokahua Stream and tributary Mokupe'a Gulch, Kahana Stream, Honokōwai Stream and tributaries Amalu and Kapāloa Streams, Wahikuli Gulch and tributary Hāhākea Gulch, Kahoma Stream and tributary Kanahā Stream, Kaua'ula Stream, Launiupoko Stream, Olowalu Stream, and Ukumehame Gulch. The results of this study can be used to assist in the determination of technically defensible instreamflow standards for the study-area streams.

Low-flow characteristics for natural (unregulated) streamflow conditions were represented by flow-duration discharges that are equaled or exceeded between 50 and 95 percent of the time. Partial-record sites were established on 10 main streams and 5 tributary streams, mainly upstream from existing surface-water diversions. Flow characteristics were determined using historical and current streamflow data from continuous-record streamflow-gaging stations and miscellaneous sites, and additional data collected as part of this study. Based on strategically scheduled observations, six of the study-area streams were ephemeral streams that were observed to remain dry at least 50 percent of the time: Pāpua Gulch, Honokahua Stream and its tributary Mokupe'a Gulch, Kahana Stream, and Wahikuli Gulch and its tributary Hāhākea Gulch. For the remaining streams with measurable flow, Honolua, Honokōwai, Kahoma, Kanahā, Kaua'ula, Launiupoko, and Olowalu Streams, and Ukumehame Gulch, flow-duration discharges were computed for the 30 -year base period (water years 1984-2013), using two record-augmentation techniques. The 95-percent flow-duration discharges ranged from 0 to 4.8 cubic feet per second $\left(\mathrm{ft}^{3} / \mathrm{s}\right)$. The 50 -percent flow-duration discharges ranged from 0.47 to $9.5 \mathrm{ft}^{3} / \mathrm{s}$.

This study also estimated the streamflow gains and losses downstream of surface-water diversions using seepage-run measurements. A majority of the streams lost flow downstream from diversions. Measured seepage-loss rates ranged between 0.045 and $1.6 \mathrm{ft}^{3} / \mathrm{s}$ per mile of stream reach. Seepage gains mostly occurred upstream from diversions and the measured seepage-gain rates generally ranged between 0.75 and $5.1 \mathrm{ft}^{3} / \mathrm{s}$ per mile of stream reach. Under naturalflow conditions, Honolua Stream is estimated to flow to the ocean less than 80 percent of the time and Honokōwai Stream is estimated to flow to the ocean less than 50 percent of the time. Kahoma Stream, Kaua 'ula Stream, Olowalu Stream, and Ukumehame Gulch are estimated to flow to the ocean at least 95 percent of the time.

\section{Introduction}

Hawai' $i$ 's surface water is a valuable resource that is critical for the economic, ecologic, and cultural growth of the islands. Traditionally, native communities depended on streams for drinking water, growing crops such as taro, raising livestock, supporting vegetation that provided materials for medicine and shelter, and other religious and cultural practices. Unique species of native freshwater animals-for example, 'o'opu (freshwater fish), 'ōpae (freshwater mountain shrimp), and hīhīwai (freshwater snail)—were important food sources for Native Hawaiians. As the sugar industry became established in Hawai ' $i$, large, engineered diversion systems were built and transported water across watersheds, resulting in reduced streamflow downstream of diversion intakes. On the island of Maui, surface water from streams in northeast Maui and the Nā Wai 'Ehā area (Waihe'e River, and Waiehu, 'Iao, and Waikapū Streams) in the eastern part of west Maui is mainly used for irrigating sugarcane cultivated in central Maui. By 1990 when sugarcane cultivation had ceased in many areas of the Hawaiian Islands, some diversion systems were abandoned, whereas others continued to divert water from streams for agricultural, industrial, and municipal uses. In the western part of west Maui, surface water is used for irrigation of coffee and other food crops, raising livestock, and domestic water supply. Many diversion structures have been constructed to capture a majority of the flow in the streams during low-flow conditions, leaving some reaches downstream from the diversion structures dry. Consequently, the diversion of surface water during low-flow conditions greatly influences water availability for ecosystems, aquatic biota, and people. 
Competition for limited water resources for offstream and instream uses has been, and continues to be, a major issue in Hawai ' $i$. Conflicts have led to costly litigation over rights to the water between those currently diverting the water and those desiring sufficient flow in the stream for instream uses. In 2001, the Native Hawaiian Legal Corporation filed a petition with the State of Hawai'i Commission on Water Resource Management (CWRM) to restore flow to 27 streams in northeast Maui (Hawaii Department of Land and Natural Resources, 2001). In 2004, Earthjustice (a non-profit public interest law organization) filed a petition on behalf of Hui o Nā Wai 'Ehā and Maui Tomorrow Foundation, Inc., to amend instream-flow standards for streams in the Nā Wai 'Ehā area (Hawaii Department of Land and Natural Resources, 2004). For both cases, streamflow data were limited or unavailable at the time the petitions were filed. Consequently, the U.S. Geological Survey (USGS), in cooperation with various agencies (Gingerich, 2005; Oki and others, 2010), provided the scientific information necessary for planning and management of the surface-water resource.

The State Water Code mandates that CWRM establish a statewide instream-use protection program (State Water Code, Hawai ‘i Revised Statutes, chapter 174C, section 71). The principal mechanism that CWRM implements for the purpose of protecting instream uses is establishing instreamflow standards that describe flows necessary to protect the public interest in the stream with consideration of existing and potential water developments, including the economic impact of restricting such use (State Water Code, Hawai ' $\mathrm{i}$ Revised Statutes, chapter 174C, section 71[1][C]). The instream uses recognized by CWRM include (1) maintenance of fish and wildlife habitat; (2) outdoor recreational activities; (3) maintenance of ecosystems; (4) aesthetic values, such as waterfalls and scenic waterways; (5) maintenance of water quality; (6) the conveyance of irrigation and domestic water supplies; and (7) the protection of traditional and customary Hawaiian rights.

Interim instream-flow standard is defined as the "amount of water flowing in each stream on the effective date of this standard, and as that flow may naturally vary throughout the year and from year to year without further amounts of water being diverted offstream through new or expanded diversions, and under stream conditions existing on the effective date of the standard..." (Hawai 'i Administrative Rules, chapter 169, section 13-169-48). The CWRM first adopted interim instream-flow standards for all streams in east Maui on June 15, 1988, and in west Maui on October 19, 1988. These interim instream-flow standards did not have quantitative flow values and allowed diversions existing at the time of the adoption to continue operating. Additional information could be filed with CWRM to reduce or increase diversion, through a modification of the interim instream-flow standards. In response to the 2001 petition to amend the interim instreamflow standards for 27 streams in northeast Maui, CWRM established quantitative interim instream-flow standards for a majority of the streams in northeast Maui that were diverted by the East Maui Irrigation System (Hawaii Department of Land and Natural Resources, 2001). Quantitative instreamflow standards that account for economic, cultural, ecologic, recreational, and aesthetic needs have not yet been established for streams in the Lahaina District of west Maui, Hawai 'i.

\section{Purpose and Scope}

This report presents results of a study conducted by the USGS, in cooperation with CWRM, to aid the agency in the determination of technically defensible instream-flow standards for streams in the Lahaina District. The objectives of the 2012-13 study were to quantify natural low-flow characteristics upstream of surface-water diversions, and characterize the seepage gains and losses downstream of surface-water diversions on a subset of streams in the Lahaina District. The main study-area streams, from north to south, include Honolua Stream, Honokahua Stream, Kahana Stream, Honokōwai Stream, Wahikuli Gulch, Kahoma Stream, Kanahā Stream, Kaua 'ula Stream, Launiupoko Stream, Olowalu Stream, and Ukumehame Gulch. Honokōhau Stream was excluded from the study because extensive research has been done by Fontaine (2003) to characterize the availability and distribution of base flow in the lower reaches of the stream, and a continuousrecord streamflow-gaging station (station 16620000, fig. 1) located upstream of the diversion intake was in operation during the study period to measure the hydrologic conditions at the gage. The scope of this investigation involved analyzing historical and current streamflow data at continuous-record streamflow- and ditch-flow gaging stations, and collecting additional data, including (1) discharge measurements at nine partial-record sites established upstream from points of surface-water diversion; (2) observations of presence or absence of flow at six partial-record sites established on ephemeral streams; and (3) seepage-run discharge measurements at selected sites in the study-area streams. This report includes estimates of selected flow-duration discharges (50 to 95 percent exceedance values) on 14 streams, estimates of seepage gains and losses on selected reaches of 8 streams, and descriptions of streams in the study area that flow from the mountains to the ocean during low-flow conditions.

Three types of streamflow-measurement sites are described in this report: (1) a continuous-record station, which provides a continuous record of discharge at a location in the stream; (2) a partial-record site, which has 10 or more systematic streamflow measurements at a location in the stream; and (3) a miscellaneous site, which has one to a few streamflow measurements that may not have been collected in a systematic manner as with a partial-record site. A long-term continuous-record station has a record length of 10 or more years and a short-term station has less than 10 years of record. A low-flow partial-record site has a series of streamflow measurements that have been made under low-flow conditions. An example of a miscellaneous site is a seepage-run measurement site where only one or two measurements have been made for the purposes of determining seepage gains and loses along a stream. 


\section{Acknowledgments}

The author is grateful to the many individuals, landowners, and agencies that provided support needed to conduct this study. Landowners that graciously allowed access to their properties include Maui Land and Pineapple Company, Inc. (ML\&P), Kā'anapali Land Management Corp. (KLM), Maui County Department of Water Supply (MDWS), West Maui Land Company, Inc. (WML), Kamehameha Schools, and Commercial Properties of Maui Management, Inc. (CPMM). The author is especially thankful to the following individuals: Jade Wagner of ML\&P, Lee-Ann Panlasigui of KLM, Tony Linder of MDWS, U'ilani Kapu of Kaua 'ula Stream valley, David Minami of WML, John Duey of Olowalu Stream valley, and Jamie Aloy of CPMM for arranging access to the studyarea streams. Pomaika'i D. Kaniaupio-Crozier and Daniel Tanaka of ML\&P shared their knowledge and insight of Honolua, Honokahua, and Kahana Stream valleys and how to safely access the streams within those areas. Robert Vorfeld of KLM provided information on hiking trail and flow conditions in the Honokōwai Stream valley. Hans and Emily Michel of Kanahā Stream valley shared the history of the valley and provided information on weather and streamflow conditions which allowed field visits to be scheduled more efficiently. Joshua Guth of WML accompanied USGS personnel on many field visits in the Kahoma Stream valley to ensure safety while traversing the hiking trail and assisted in preparing the discharge-measurement site. USGS personnel, Sarah N. Rosa and Benjamin H. Shimizu, participated in conducting discharge measurements and the planning of seepage-run analyses. Matt Wong and Casey Rita expedited analysis of water year 2013 hydrologic data for continuous-record gaging stations for use in the study (see "Flow-Duration Characteristics" section for explanation of "water year").

\section{Description of the Study Area}

The study area encompasses 10 stream valleys within the Lahaina District-from Honolua in the north to Ukumehame in the south-which drain the western half of the West Maui Volcano. The drainage areas at the mouths of the streams range from 2.5 to 8.4 square miles $\left(\mathrm{mi}^{2}\right)$, with Launiupoko being the smallest and Honokōwai the largest. Lahaina and Nāpili are the main population centers within the study area. The study-area streams, from north to south, include Honolua Stream and its tributary Pāpua Gulch, Honokahua Stream and its tributary Mokupe'a Gulch, Kahana Stream, Honokōwai Stream and its tributaries Amalu and Kapāloa Streams, Wahikuli Gulch and its tributary Hāhākea Gulch, Kahoma Stream and its tributary Kanahā Stream, Kaua 'ula Stream, Launiupoko Stream, Olowalu Stream, and Ukumehame Gulch (fig. 1). Low-flow characteristics of streams are mainly affected by (1) the physical attributes of the valleys such as topography, land cover, land use, and geology; (2) climate and rainfall; and (3) regulation and withdrawal of streamflow.

\section{Physical Setting}

The island of Maui has an area of about $728 \mathrm{mi}^{2}$, making it the second largest of the Hawaiian Islands (Stearns and Macdonald, 1942). Maui was built by two major shield volcanoes (fig. 2), the older West Maui Volcano (West Maui Mountain) that rises to an altitude of 5,788 feet (ft) at $\mathrm{Pu}$ ' $\mathrm{u}$ Kukui and the younger East Maui Volcano (Haleakalā) that rises to an altitude of $10,025 \mathrm{ft}$ at $\mathrm{Pu}^{\prime} \mathrm{u}$ 'Ula 'ula (Red Hill). A relatively flat central isthmus was formed when the East Maui Volcano lava flows banked against the preexisting West Maui Volcano. The West Maui Volcano is highly eroded and deeply dissected into several high peaks that are collectively identified as the West Maui Mountain with a summit at $\mathrm{Pu}$ ' $\mathrm{u}$ Kukui. The upper slopes of the mountains are mainly forested conservation land, the lower slopes are used for agriculture, and the coastal areas are developed for residential and recreational purposes.

Geology, as it relates to the composition and permeability of streambeds, is an important physical characteristic affecting low flows because the natural low flow in a stream is mainly from groundwater sources. Detailed descriptions of the geology and the hydraulic properties of the volcanic rocks in the Lahaina District can be found in Stearns and Macdonald (1942) and Gingerich and Engott (2012). West Maui Volcano has a central caldera and two main rift zones that extend northwest and southeast from the caldera (see figure 4 in Gingerich and Engott, 2012). Numerous dikes exist near the caldera and within the rift zones at higher altitudes, and these low-permeability dikes can impound groundwater levels to as high as 3,000 ft above sea level (Stearns and Macdonald, 1942, p. 195). Gingerich and Engott (2012) estimated the extent of the dike-impounded water body in west Maui from dikes exposed in valley walls, tunnels, water levels in wells, and streamflow (fig. 2). Dike-impounded groundwater maintains perennial flow in some of the study-area streams at the upper reaches where they intersect the dike-impounded water body. These stream reaches are "gaining reaches" because groundwater contributes to streamflow. In stream valleys where extensive erosion has exposed dike compartments, groundwater from these dike-impounded systems discharges directly to streams. Downstream from the area of dikeimpounded groundwater, the water table of the freshwater-lens aquifer system is below the streambed. In many of the studyarea streams, the lower altitude reaches are "losing reaches" because streamflow discharges to the groundwater body. Some streams may lose all flow to the groundwater body before reaching the ocean during low-flow conditions. Volcanic rocks within the study area consist mainly of Wailuku Basalt, which are very permeable, and in dike-free zones these rocks provide an important source of fresh groundwater through the freshwater-lens aquifer system. 


\section{Low-Flow Characteristics of Streams in the Lahaina District, West Maui, Hawai'i}
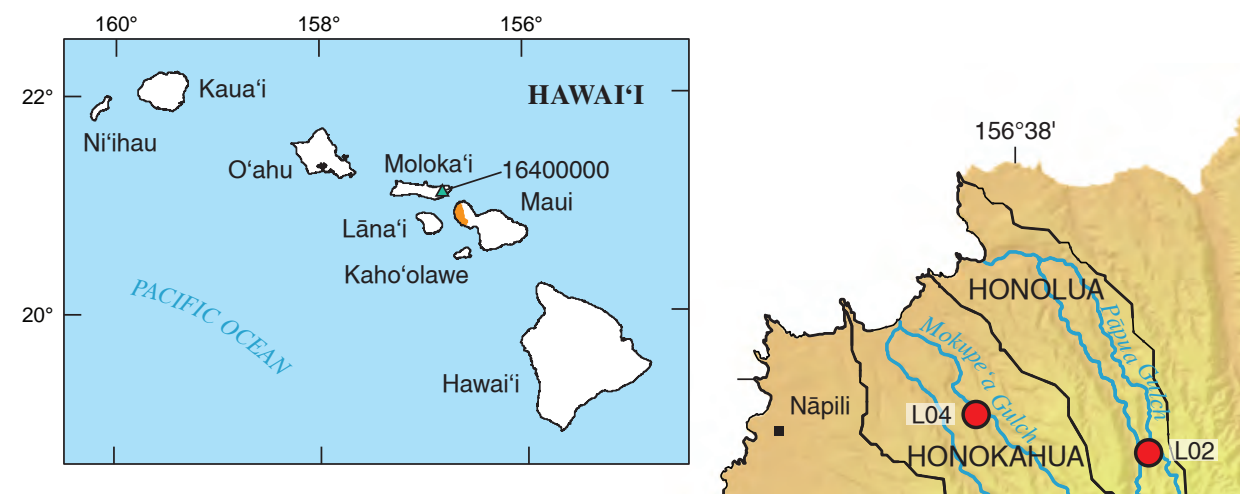


\section{Climate and Rainfall}

The topography of Maui and the position of the North Pacific subtropical anticyclone relative to the island produce an atmosphere characterized by mild and uniform temperatures, cool and persistent trade winds, and seasonal and geographic variability in rainfall (Blumenstock and Price, 1967; Schroeder, 1993). Rainfall is generated from the rising and cooling of moisture-laden trade winds along the windward slopes of the islands. During the dry season (May-September), persistent northeasterly trade winds blow 80-95 percent of the time. During the rainy season (October-April), other migratory weather systems that affect the Hawaiian Islands cause a reduction in trade-wind frequency to 50-80 percent of the time. Heavy and intense rainfall can be caused by low-pressure systems from the northwest and those accompanied with southerly winds (Kona storms), cold fronts associated with mid-latitude cyclones, and tropical cyclones from the eastern Pacific Ocean (Giambelluca and Schroeder, 1998). Dry coastal areas can receive most of their annual rainfall amounts from these storms.

On west Maui, orographic ascent of trade winds up the windward slopes produces persistent rainfall at $\mathrm{Pu}$ 'u Kukui. The leeward slopes are dry and the coastal areas are dominated by sea and valley breezes; although trade winds often occur to the north at Kă'anapali and south at Olowalu (Schroeder, 1993, p. 34). Rainfall in the study area is characterized by steep spatial gradients with increasing altitude (fig. 2). Mean annual rainfall ranges from about 366 inches at Pu'u Kukui to less than 50 inches in the coastal areas (Giambelluca and others, 2013). Within one mile (mi) of Pu'u Kukui, mean annual rainfall can vary by more than 140 inches. Engott and Vana (2007) determined that fog interception contributes as much as 20 percent of annual rainfall in the upper slopes. In 2012, the annual rainfall total recorded at the $\mathrm{Pu}$ 'u Kukui raingaging station (USGS station 205327156351102, fig. 1) was about 261 inches, 28 percent below the mean annual rainfall for 1978-2007. March had the highest monthly rainfall total (about 43 inches), and January and October had the lowest monthly rainfall totals (less than 5 inches).

The headwaters (the source and upper reaches of a stream) of Honokōwai and Kahoma Streams receive the highest mean annual rainfall (over 320 inches) in the study area. The headwaters of Kaua 'ula Stream and Wahikuli Gulch receive a mean annual rainfall of about 240 inches. The headwaters of Honolua, Kahana, and Olowalu Streams receive 180-200 inches of rainfall per year. The headwaters of Honokahua and Launiupoko Streams, and Ukumehame Gulch receive less than 140 inches of rainfall per year.

\section{Surface-Water Diversions}

The following sections describe the historical and current (study period 2012-13) conditions related to the diversion and uses of surface water from streams in the Lahaina District. Data that describe historical diverted conditions do not apply to the present day; however, they provide information that is useful for understanding the diversion practices that are occurring at present. Discussions on the current diverted conditions may help with the assessment of surface-water uses and needs in the study area, and the determination of instream-flow standards for the study-area streams. The historical setting is summarized from Wilcox (1996), archived USGS records, and records provided by CWRM. Information on the current setting is gathered from County of Maui and State of Hawai'i reports, accounts from current landowners within the study area, and visual observations during field investigations. The current conditions related to the diversion and uses of surface water in the study area apply to the period of the study and may not represent future conditions because landownership and the uses of water may change. Locations of streamflow-gaging stations are shown in figure 1. Locations of major diversion systems and associated intakes and ditch-flow gaging stations discussed in the following sections are shown in figure 3.

\section{Historical Setting}

According to Wilcox (1996, p. 126), plantation-scale diversion systems in the Lahaina District began with Pioneer Mill Company (hereafter referred as Pioneer Mill) and Maui Land and Pineapple Company (ML\&P). Pioneer Mill began sugarcane cultivation in the late 1800s and obtained surface water for irrigation with eight separate diversion systems. By 1931, Pioneer Mill was using 50 to 60 million gallons per day (Mgal/d) (77-93 cubic feet per second; $\mathrm{ft}^{3} / \mathrm{s}$ ) of surface water to irrigate its sugarcane plantation. The most extensive diversion system was Honokōhau Ditch (also known as Honolua Ditch) (fig. 3), which was completed in 1904, rebuilt in 1913, and extensively renovated during 1923-28. ML\&P constructed and maintained Honokōhau Ditch, and sold the water to Pioneer Mill. Beginning in the early 1900s, ML\&P cultivated pineapple on the northwest slope of West Maui Mountain (Hawkins, 2011, p. 130). ML\&P operations also included raising livestock and farming other food crops (Maui Land \& Pineapple Company, Inc., 2013).

Surface water from Honokōhau and Honolua streams was diverted into Honokōhau Ditch. The diversion intake on Honokōhau Stream is located at an altitude of $825 \mathrm{ft}$ (Fontaine, 2003, p. 8). Records at USGS ditch-flow gaging station 16621000 (fig. 3) in Honokōhau Ditch indicated an average flow of $34.4 \mathrm{ft}^{3} / \mathrm{s}$ was diverted from Honokōhau Stream during March 1907 to August 1913 (Fontaine, 2003, p. 11). The diversion intake on Honolua Stream is located at an altitude of 800 ft. From April 1913 through June 1917, the USGS operated a streamflow-gaging station on Honolua Stream (station 16623000, fig. 1) about $300 \mathrm{ft}$ upstream from the Honokōhau Ditch intake. The diversion intake is a metal grate that spans the entire width of the stream and it probably captured a majority of the low flow in the stream. Therefore, records at the streamflow-gaging station could provide insight to the average amount of water diverted from Honolua Stream into 


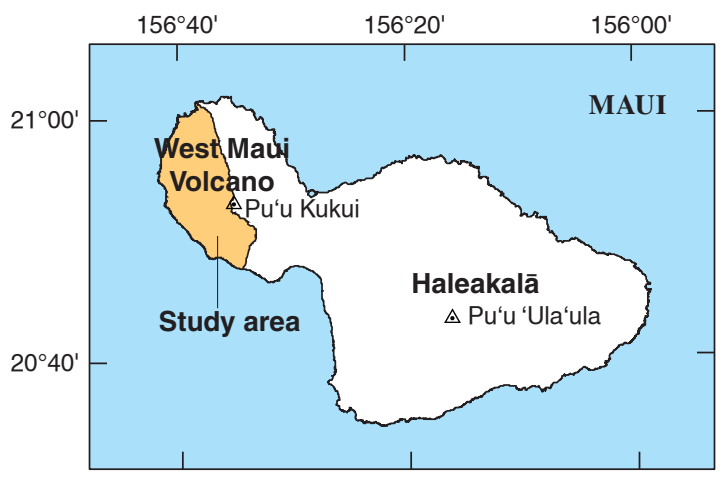

EXPLANATION

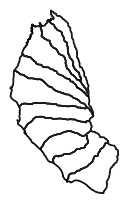

Study area and boundaries between stream areas

(modified from Hawai'i Office of Planning, 2013)

\section{Area with dike-impounded groundwater} (modified from Gingerich and Engott, 2012)

Mean annual rainfall, in inches

(modified from Giambelluca and others, 2013)

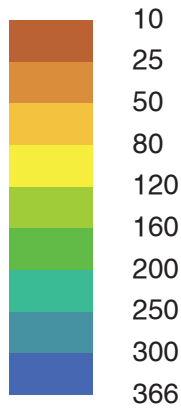

Base modified from U.S. Geological Survey digital data. Universal Transverse Mercator projection, zone 4, North American Datum 1983.

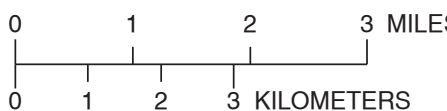

Figure 2. Map of mean annual rainfall, west Maui, Hawai'i. 
Honokōhau Ditch. An average flow of $9 \mathrm{ft}^{3} / \mathrm{s}$ was recorded at station 16623000 during the period the gage was in operation. Pioneer Mill monitored ditch flow in Honokōhau Ditch near Māhinahina. CWRM records indicate the 1988-99 average flow was about $30 \mathrm{ft}^{3} / \mathrm{s}$ in Honokōhau Ditch near Māhinahina.

Pioneer Mill's second largest diversion system was Honokōwai Ditch (fig. 3). The main sources of surface water for Honokōwai Ditch are Amalu and Kapāloa Streams, tributaries of Honokōwai Stream, and the diversion intakes are located at altitudes of 1,600 and 1,560 ft, respectively. Records at USGS ditch-flow gaging station 16629000 in Honokōwai Ditch, about 1,000 ft downstream from the diversion intake on Kapāloa Stream, indicate an average flow of $8.8 \mathrm{ft}^{3} / \mathrm{s}$ from July 1912 through September 1967. CWRM records indicate the 1988-99 average flow was $8.5 \mathrm{ft}^{3} / \mathrm{s}$ in Honokōwai Ditch, although the location of the measurement site was uncertain.

The remaining six smaller diversion systems are Kahoma, Kanahā, Kaua 'ula, Launiupoko, Olowalu, and Ukumehame systems (fig. 3), named after the streams from which the systems diverted water. The Kahoma system diverted water from various locations along Kahoma Stream. According to USGS records, the upstream-most diversion intake (pipeline intake) was located at an altitude of about 2,000 ft, where a loose rock dam channeled low flows into a small pipeline that discharged water into the Kahoma development tunnel located about $200 \mathrm{ft}$ downstream from the pipeline intake. Records at USGS gaging station 16633000 (fig. 3), which measured combined flow from the pipeline and the tunnel, indicate an average flow of $4.7 \mathrm{ft}^{3} / \mathrm{s}$ between August 1911 and June 1917. A majority of this flow was from the development tunnel, which delivered an average flow of $3.1 \mathrm{ft}^{3} / \mathrm{s}$ (Wilcox, 1996, p. 136). All the flow from the pipeline and tunnel was diverted into a flume that discharged directly into the upper Kahoma Ditch at an altitude of 1,920 ft. Prior to November 24, 1914, when part of the flume was removed, very little flow remained in the stream downstream of the pipeline intake. Records at USGS streamflow-gaging station 16634000 (fig. 1), located $125 \mathrm{ft}$ upstream from the upper Kahoma Ditch intake, indicate a mostly dry stream and occasional periods with flow when streamflow may have exceeded the capacity of the pipeline intake. Subsequent to the removal of the flume, flow from the pipeline and the development tunnel was discharged into the stream and then diverted at the upper Kahoma Ditch intake. CWRM records indicate the 1988-99 average flow was about $7.9 \mathrm{ft}^{3} / \mathrm{s}$ in upper Kahoma Ditch. The downstream-most diversion on Kahoma Stream was located at an altitude of $960 \mathrm{ft}$ (lower intake). This intake diverted water into a wooden flume and eventually to the sugarcane fields. No data were available to estimate the average amount of water diverted by the lower intake.

The Kanahā diversion system supplied water to Pioneer Mill, Lahainaluna School, and MDWS (fig. 3). The diversion system had two major intakes on Kanahā Stream that most likely captured all of the low flow in the stream. The upper intake, located at an altitude of 1,120 ft, diverted water into upper Kanahā Ditch (formerly Lahainaluna School pipeline) where the water was then split between a hydroelectric plant and a MDWS reservoir. Diverted water that flowed past the hydroelectric plant discharged to lower Kanahā Ditch (formerly lower Lahainaluna School Ditch), which supplied water to Pioneer Mill's sugarcane fields. Records at streamflowgaging station 16636000 (fig. 1), located $200 \mathrm{ft}$ upstream of the upper intake, indicate an average flow of $7.7 \mathrm{ft}^{3} / \mathrm{s}$ from July 1916 through June 1932. The lower intake, located at an altitude of $520 \mathrm{ft}$, diverted water into lower Kanahā Ditch. Records at USGS streamflow-gaging station 16638000 (fig. 1), located about $200 \mathrm{ft}$ upstream from the lower intake, indicate an average flow of $5.7 \mathrm{ft}^{3} / \mathrm{s}$ between August 1911 and January 1916. Overflow from the upper ditch discharged into the stream immediately upstream of the lower intake, which contributed additional flow to the lower ditch at times. CWRM records indicate the 1988-99 average flow was $2.4 \mathrm{ft}^{3} / \mathrm{s}$ in Kanahā Ditch, although the location of the monitored ditch flow was uncertain.

The Kaua 'ula diversion system consists of one intake on Kaua 'ula Stream at an altitude of 1,540 ft (fig. 3). Surface water diverted at the intake was used to run a hydroelectric plant before being transported to the sugarcane fields. Records at USGS ditch-flow gaging station 16643000 (fig. 3) in Kaua 'ula Ditch about $100 \mathrm{ft}$ downstream from the intake indicate an average flow of $9.4 \mathrm{ft}^{3} / \mathrm{s}$ was diverted into the ditch during January 1912 to June 1917. CWRM records indicate the 1988-99 average flow was about $9.5 \mathrm{ft}^{3} / \mathrm{s}$ in Kaua'ula Ditch.

The Launiupoko diversion system consists of one intake on Launiupoko Stream at an altitude of 1,230 ft (fig. 3). CWRM records indicate the 1988-99 average flow was $0.88 \mathrm{ft}^{3} / \mathrm{s}$ in Launiupoko Ditch and Wilcox (1996, p. 137) reported a median flow in Launiupoko Ditch of $1.2 \mathrm{ft}^{3} / \mathrm{s}$.

The Olowalu and Ukumehame diversion systems were originally owned by Olowalu Plantation before the plantation was acquired by Pioneer Mill in the early 1930s (Wilcox, 1996, p. 137). The Olowalu diversion system consisted of two major intakes on Olowalu Stream, at altitudes of $520 \mathrm{ft}$ and $200 \mathrm{ft}$ (fig. 3). Water diverted at the upper intake was used for power generation at a hydroelectric plant and for sugarcane irrigation. Records at USGS ditch-flow gaging station 16645000 in upper Olowalu Ditch, located $40 \mathrm{ft}$ upstream of the hydroelectric plant penstock pipe, indicate an average flow of $7.5 \mathrm{ft}^{3} / \mathrm{s}$ was diverted from Olowalu Stream during September 1911 to September 1967. CWRM records indicate the 1988-99 average flow was about $6.6 \mathrm{ft}^{3} / \mathrm{s}$ in upper Olowalu Ditch. Wilcox (1996, p. 137) reported a median flow of $6.3 \mathrm{ft}^{3} / \mathrm{s}$ in upper Olowalu Ditch. Available data were insufficient to determine the amount of water diverted by the lower Olowalu Ditch intake. The Ukumehame diversion system, with a capacity of about $24 \mathrm{ft}^{3} / \mathrm{s}$ (Wilcox, 1996, p. 137), has an intake on Ukumehame Gulch at an altitude of $240 \mathrm{ft}$ (fig. 3). Water diverted at this intake flowed through Ukumehame Ditch (formerly Olowalu Plantation Ditch) to the sugarcane fields. CWRM records indicate the 1988-99 average flow was about $6.0 \mathrm{ft}^{3} / \mathrm{s}$ in Ukumehame Ditch, and Wilcox (1996, p. 137) reported a median flow of $5.1 \mathrm{ft}^{3} / \mathrm{s}$ in Ukumehame 
Ditch. In addition to the Ukumehame Ditch intake, another intake is located at an altitude of $270 \mathrm{ft}$ on Ukumehame Gulch. An unquantified amount of water diverted at this intake was used for taro cultivation.

\section{Current Setting}

Since Pioneer Mill ceased sugarcane cultivation in September 1999 (Kubota, 1999), ownership of the land and the diversion systems, as well as the use of surface water in the Lahaina District have changed. Former Pioneer Mill lands were bought by ML\&P and other private entities. The private entities that own the lands also own the diversion systems within their properties, and are responsible for maintaining those parts of the systems. ML\&P's property covers the valleys of Honokōhau, Honolua, Honokahua, Kahana, and the northern part of Honokōwai Streams within the study area. While the Honokōhau Ditch diversion intake on Honokōhau Stream remains active, the diversion intake on Honolua Stream (fig. 4A) was not diverting water from the stream during the study period. Subsequent to the closure of ML\&P's pineapple operation in the Lahaina District in 2009, the main uses of surface water diverted by ML\&P from Honokōhau Ditch have been mainly for irrigating small-scale diversified agricultural lots and golf courses, raising livestock, providing for domestic water supply, and supporting reforestation efforts (Pomaika' $\mathrm{i}$ D. Kaniaupio-Crozier, Maui Land and Pineapple Company, Inc., oral commun., 2013). The MDWS also diverts water from Honokōhau Ditch to provide potable water for the residential population in the coastal areas from Nāpili to Honokōwai (PBR Hawaii, 2004, p. 5-1). Water diverted from Honokōhau Ditch is treated at the MDWS Māhinahina Water Treatment Facility (fig. 3). CWRM records indicate an average daily production of about 1.5 million gallons (Mgal) $\left(2.32 \mathrm{ft}^{3} / \mathrm{s}\right)$ from 2009 to 2010 at the Māhinahina Water Treatment Facility.

A part of the Honokōwai Stream and Wahikuli Gulch valleys, as well as the Honokōwai diversion system, are currently owned by KLM. The Honokōwai diversion system continues to divert water from Amalu and Kapāloa Streams (fig. 4B). From 2002 to 2012, the average flow diverted into the Honokōwai diversion system was estimated to be $4.2 \mathrm{ft}^{3} / \mathrm{s}$ (Robert Vorfeld, Kā‘anapali Land Management Corp., oral commun., 2013). Surface-water use by KLM is mainly for irrigating its coffee plantation in the former sugarcane fields located on the lower slopes of Wahikuli Gulch and providing nonpotable water supply to the subdivision in the valley. KLM also supplements its surface-water use with water from Honokōhau Ditch.

A majority of the Kahoma Stream valley is owned and (or) managed by Kamehameha Schools (KS) and West Maui Land Company, Inc. (WML). The pipeline intake (at an altitude of 2,000 ft) and the lower Kahoma Ditch intake (at an altitude of $960 \mathrm{ft}$ ) have been abandoned since the closure of Pioneer Mill. Upper Kahoma Ditch (fig. 4C) remains in operation, and water diverted from Kahoma Stream is used by WML to support ecotourism activities within the valley (Joshua Guth, West Maui Land Company, Inc., oral commun., 2013). According to diversion records provided by CWRM, the amount of water diverted at the upper Kahoma Ditch intake has decreased over the past 6 years, from an average flow of $8 \mathrm{ft}^{3} / \mathrm{s}$ in 2007 to $0.27 \mathrm{ft}^{3} / \mathrm{s}$ in 2012 .

Lower Kanahā Stream valley is privately owned and the upper valley is owned by the State of Hawai' $\mathrm{i}$. A majority of the Kanahā diversion system has been abandoned with the exception of the upper ditch, where the upper intake (altitude of 1,120 ft, fig. 4D) diverts water from Kanahā Stream to provide potable water for the residential population in the coastal areas from Kā'anapali to Launiupoko (PBR Hawaii, 2004, p. 5-1). Water diverted from the stream is treated at the MDWS Lahaina Water Treatment Facility (fig. 3). According to diversion records provided by CWRM, the average daily production for 2009 to 2010 at the Lahaina Water Treatment Facility was about 1.4 Mgal. The MDWS supplements potable-water needs with groundwater sources (Maui County Planning Department, 2012, p. 6-17).

A majority of the Kaua 'ula, Launiupoko, and Olowalu Stream valleys and the individual diversion systems (see upper intake on Olowalu Stream, fig. 4E) within the valleys are owned by WML. During the study period, all the diversion systems were diverting surface water to provide for agricultural and municipal uses within the valleys (David Minami, West Maui Land Company, Inc., written commun., 2012). Water used for municipal purposes is treated by private water companies subsidiary to WML. Surface water diverted from Kaua 'ula Stream continues to support a hydroelectric plant. Olowalu Stream water is diverted to support taro cultivation in the lower valley. According to diversion records provided by CWRM, average flows diverted from Kaua'ula, Launiupoko, and Olowalu Streams between January 2007 and December 2012 were $7.0,0.58$, and $4.4 \mathrm{ft}^{3} / \mathrm{s}$, respectively.

A small part of the Ukumehame Gulch valley near the coast is owned by County of Maui and the remainder is residential and agricultural lots that are privately owned. The Ukumehame diversion system remains in operation and surface water diverted by the system from Ukumehame Gulch is used for agricultural and municipal purposes (Jamie Aloy, Commercial Properties of Maui Management, Inc., oral commun., 2013). Water for municipal use is treated by a private water company. No data are available to estimate the amount of water diverted at the Ukumehame Ditch intake (altitude of $240 \mathrm{ft}$, fig. 4F). During the study period, water was observed to flow past the diversion dam at the intake during low-flow periods, and the stream reach downstream from the diversion was never observed to be dry. Therefore, Ukumehame Ditch may capture only a part of the flow in the stream. The taro diversion intake at an altitude of $270 \mathrm{ft}$ remains in operation and no data are available to estimate the average amount of water diverted at the taro intake. 


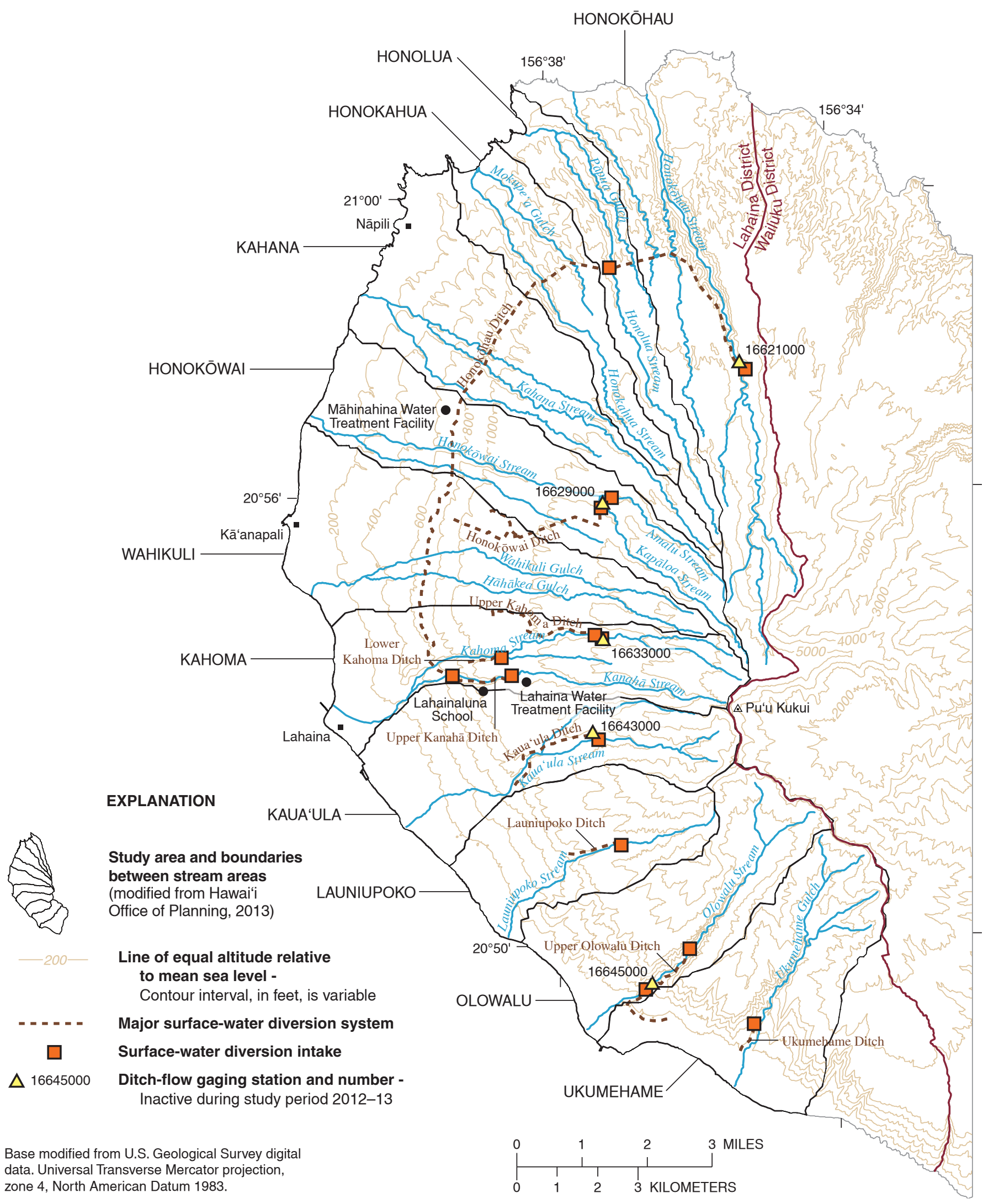

Figure 3. Map showing locations of major diversion systems and associated intakes, and U.S. Geological Survey ditchflow gaging stations in the study area, west Maui, Hawai'i. 

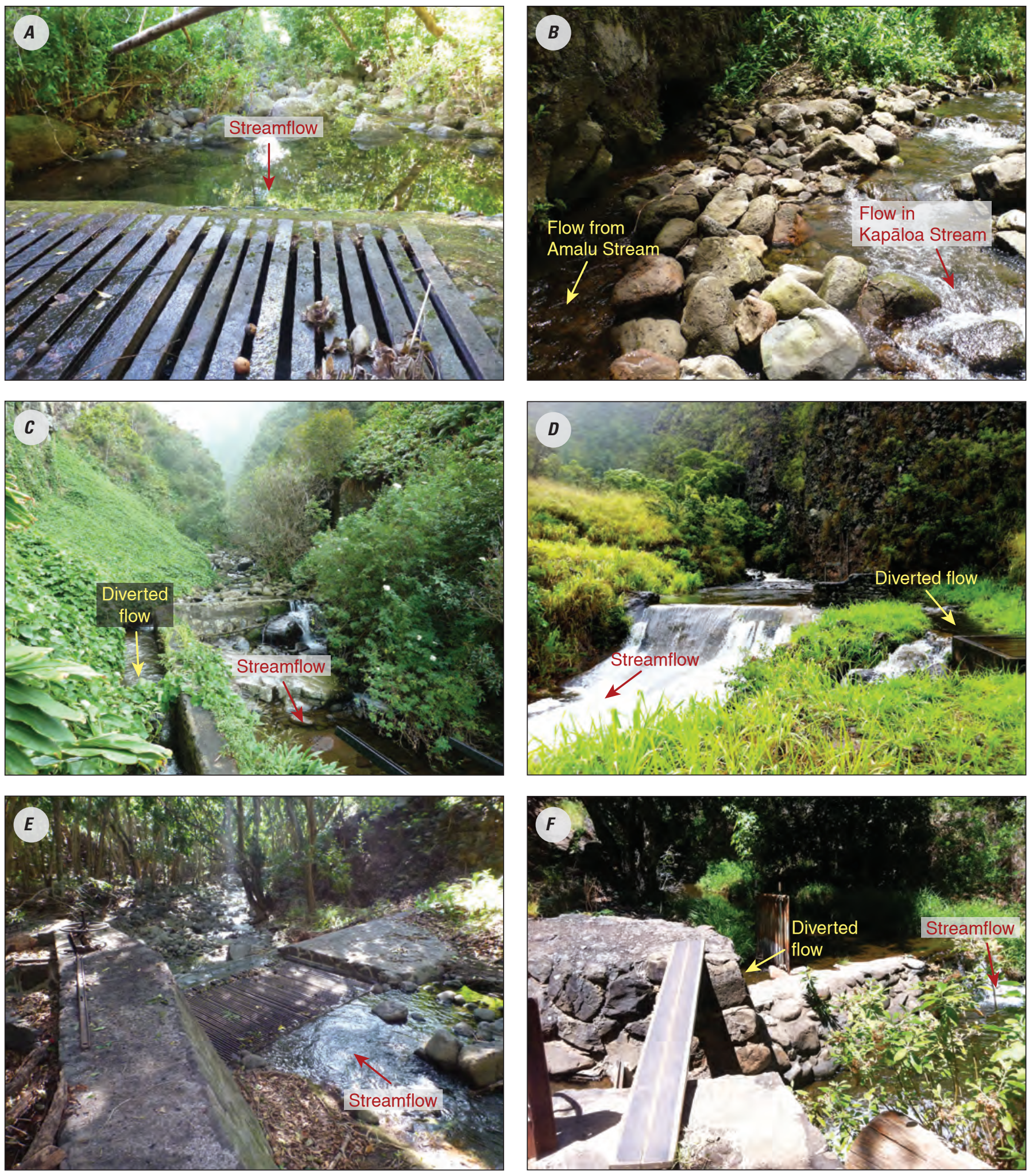

Figure 4. Photographs of select diversion intakes in the study area, west Maui, Hawai'i. A, Diversion intake on Honolua Stream. Photograph from State Commission on Water Resource Management (CWRM). B, Diverted flow from Amalu Stream from the transmission tunnel to Kapāloa Stream. Photograph from CWRM. C, Upper intake on Kahoma Stream. D, Upper intake on Kanahā Stream. E, Upper intake on Olowalu Stream. Photograph from CWRM. F, Diversion intake on Ukumehame Gulch. 


\section{Historical Streamflow Data}

Streamflow data that describe the historic natural lowflow conditions of the study-area streams are limited. For the purposes of this report, data collected prior to year 1990 from inactive continuous-record streamflow-gaging stations and miscellaneous measurement sites are included in this discussion. Historically, the USGS operated 10 continuous-record streamflow-gaging stations in the study area (fig. 1, table 1). Five of the stations-stations 16623000, 16636000, 16641000, 16644000 , and 16647000 - were located upstream of diversion intakes; therefore, they monitored natural streamflow. Station 16634000 on Kahoma Stream was located below the pipeline intake and records at this station subsequent to the removal of the flume on November 24, 1914, indicate unregulated streamflow. The gaging station on Kanahā Stream (station 16636000) had the longest recorded period of unregulated streamflow (1916-32); the remaining 5 short-term stations were operated for less than 10 years. Stations 16630000 and 16638000 were located on the intermediate reaches of Honokōwai and Kanahā Streams, respectively, downstream of the uppermost diversions; therefore, they monitored regulated streamflow. Two of the ten gaging stations (16638500 and 16646200) were located near the coast - downstream from all diversions - and monitored regulated streamflow.

Miscellaneous discharge measurements were made between 1911 and 1967 at seven of the streams in the study area (table 2). Discharge measurements on Ukumehame Gulch were made shortly after the discontinuation of USGS streamflow-gaging station 16647000 . Historical measurements made as part of seepage runs are discussed in subheading "Streamflow Gains and Losses" under the Results and Discussion section of this report.

\section{Previous Low-Flow Investigations}

Previous low-flow investigations of Hawaiian streams have been largely conducted on a basin-scale basis, with a focus on computing a selected range of low-flow duration statistics and examining the effects of surface-water diversions on low flows and habitat availability for native stream fauna. The application of record-augmentation methods for estimating low-flow characteristics at sites with either short-term records or partial-records of streamflow data is well documented. Fontaine and others (1992) estimated natural and regulated median streamflows for ungaged, perennial streams in the State of Hawai 'i. Fontaine (2003) quantified base-flow availability and the effects of streamflow diversions and return flows on base-flow availability in Honokōhau Stream, Maui. Gingerich (2005) assessed the effects of streamflow diversions on flow characteristics for perennial streams in northeast Maui. A subsequent study by Gingerich and Wolff (2005) examined the effects of streamflow diversions on instream temperatures and habitat availability for native stream fauna in the same study area, northeast Maui. Oki and others (2006) characterized natural low-flow availability in Punalu 'u Stream, $\mathrm{O}{ }^{\prime} \mathrm{ahu}$, and examined the effects of streamflow diversions on habitat availability for native stream fauna. Yeung and Fontaine (2007) described natural and regulated low flows for streams that were affected by the Waiāhole Ditch System in northeast O'ahu. Oki and others (2010) assessed the effects of streamflow diversions on low flows, groundwater recharge, habitat for native stream fauna, and instream temperatures for streams in the Nā Wai 'Ehā area, Maui. Fontaine (2012) quantified natural and regulated low-flow characteristics for streams in Waipi 'o Valley, Hawai ' $i$, and evaluated implications of proposed streamflow diversion strategies on low flows. Cheng and Wolff (2012) characterized availability and distribution of low flow in Anahola Stream, Kaua 'i, and assessed flow availability for agricultural use under a variety of potential instream-flow standards established for Anahola Stream. 


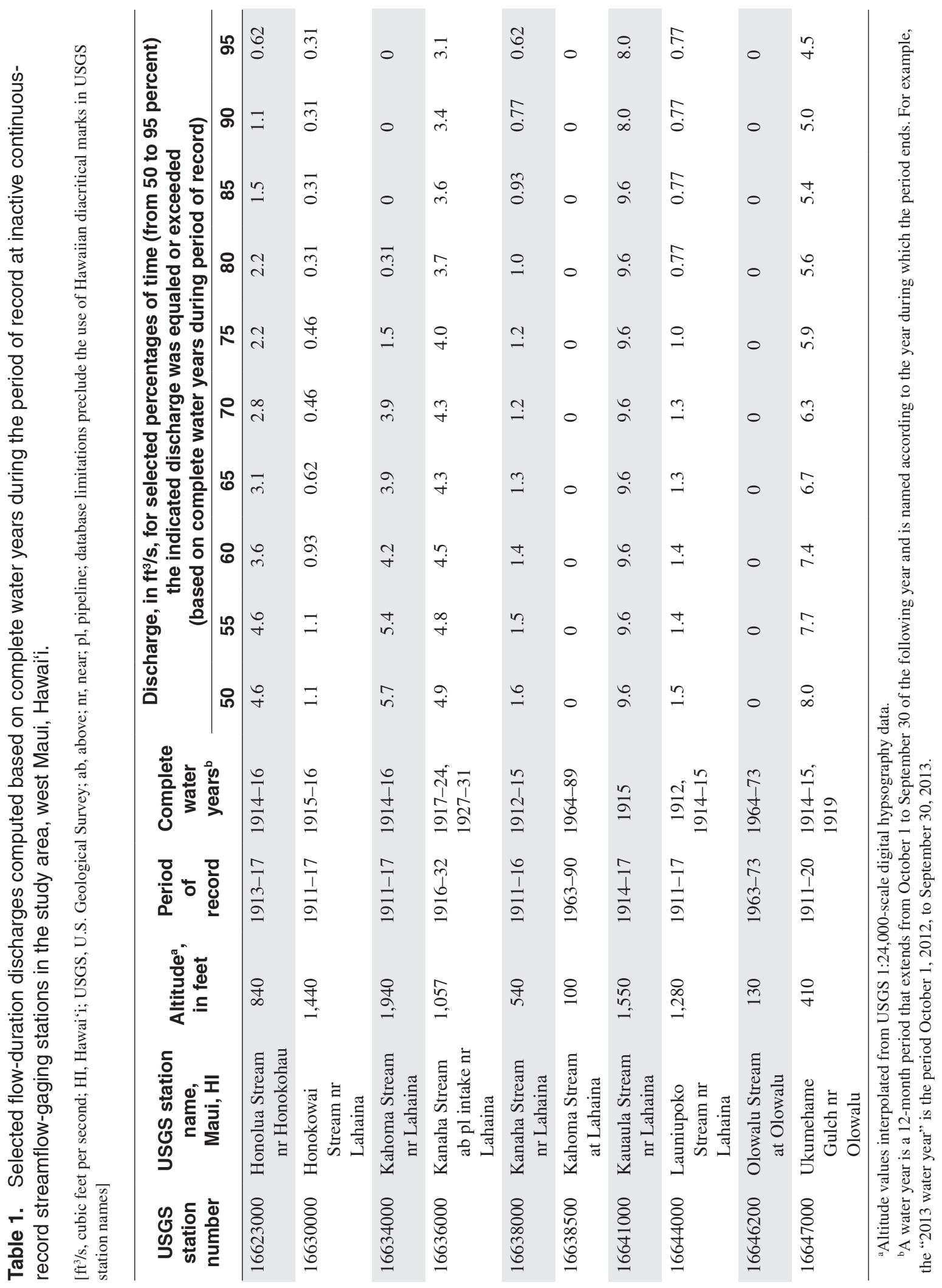




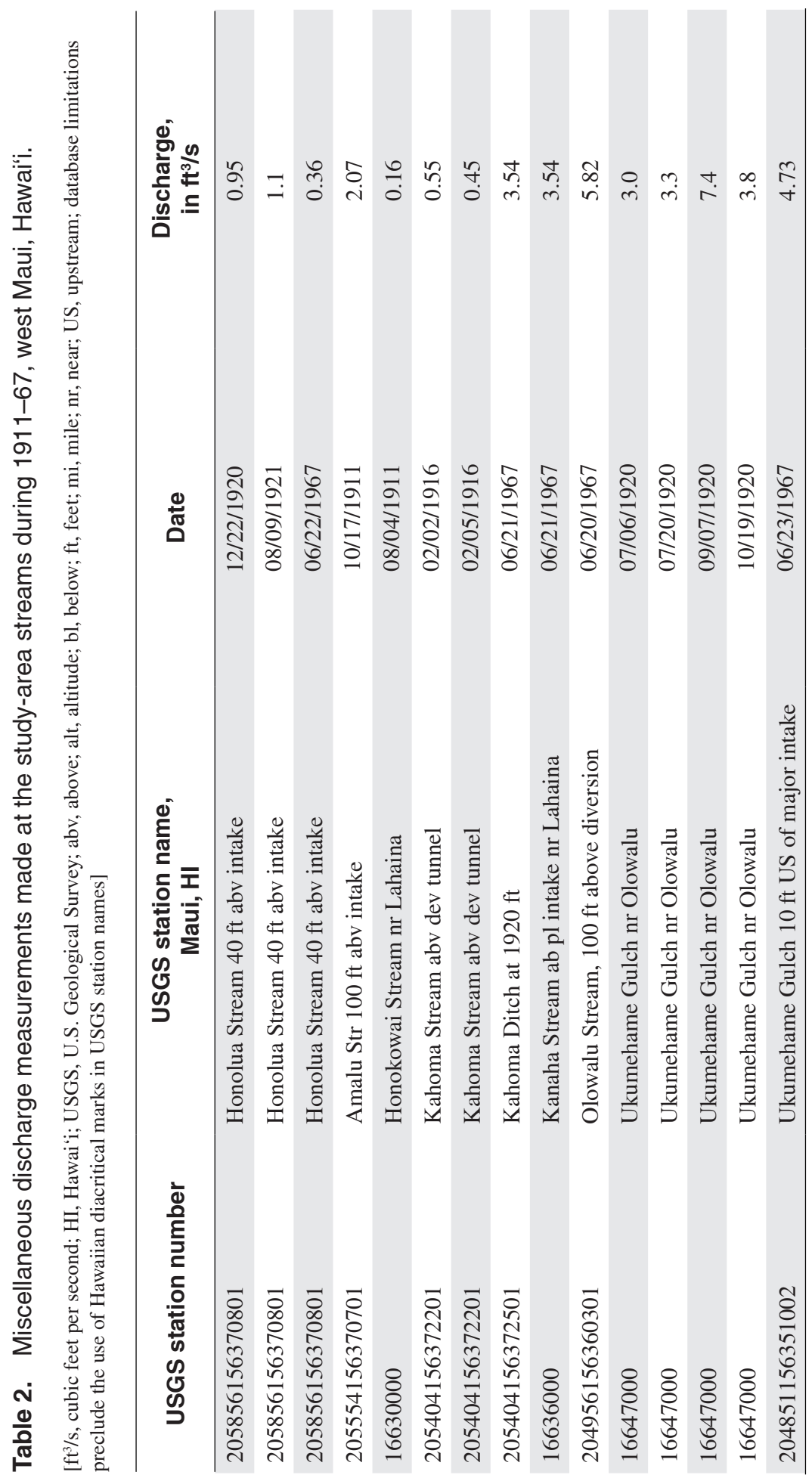




\section{Methods}

\section{Flow-Duration Characteristics}

Low-flow characteristics, under natural (unregulated) streamflow conditions, of the study-area streams are described using flow-duration discharges. Natural-flow conditions represent streamflow that is not affected by surface-water diversions and irrigation return flows. Flow-duration curves provide an informative method of displaying the complete range of flows in a stream and have been extensively used for hydrologic planning and design (Vogel and Fennessey, 1995), especially in the field of water-resource management. A flow-duration curve is a cumulative-frequency distribution that shows the percentage of time that specified discharges at a location in a stream are equaled or exceeded over a given period of record; hence, the curve shows the relation between magnitude and frequency of streamflow. The period of record is commonly expressed in water years. A water year is a 12-month period that extends from October 1 to September 30 of the following year and is named according to the year during which the period ends. For example, the " 2013 water year" is the period October 1, 2012, to September 30, 2013.

Daily mean discharges are typically used to construct the flow-duration curves because they allow for more detailed examination of the duration characteristics of a stream (Smakhtin, 2001, p. 154) compared to flow-duration curves constructed from weekly, monthly, or annual streamflow data. A flow-duration curve is constructed by first ranking the daily mean discharges for a given period of record in descending order, then computing the exceedance probability of each discharge, and finally plotting the discharges against their exceedance probabilities (Ries and Friesz, 2000, p. 8). The exceedance probabilities are computed with the Weibull formula (Loaiciga, 1989, p. 82):

$$
P_{k}=\frac{k}{n+1}, k=1,2,3, \ldots n
$$

where

$$
\begin{array}{cc}
P_{k} & \text { is the exceedance probability of a daily mean } \\
& \text { discharge with rank k; } \\
k & \text { is the rank of a daily mean discharge; and } \\
n & \text { is the total number of daily mean discharges } \\
& \text { for the given period of record. }
\end{array}
$$

The 50-percent flow-duration discharge, commonly referred to as median $\left(\mathrm{Q}_{50}\right)$ discharge, is one of the most valuable and frequently computed flow-duration statistics. The $\mathrm{Q}_{50}$ discharge is the flow that has been equaled or exceeded 50 percent of the time during a given period of record. Flow-duration discharges that describe low-flow conditions are generally considered to be those equal to or less than the $\mathrm{Q}_{50}$ discharge, and they are represented by the lower end of the flow-duration curve. For this study, natural low-flow characteristics of the study-area streams are represented by selected flow-duration discharges between the $\mathrm{Q}_{95}$ and $\mathrm{Q}_{50}$ (95- and 50-percent, respectively) discharges.

\section{Record Augmentation}

Record augmentation is an index-streamgage approach in which streamflow information from a continuously gaged basin (index station) is transferred to a basin with limited streamflow data (Eng and others, 2011). This method is commonly used to determine flow-duration discharges at sites with partial-record streamflow data. Record augmentation involves correlating discharge measurements at the partial-record site with concurrent daily mean discharges at a nearby long-term continuous-record streamflow-gaging station (index station) to develop a statistical relation. The statistical relation is then used to compute flow-duration discharges at the partial-record site from corresponding flow-duration discharges at the index station for the base period. The base period is a common period during which all index stations used in the analysis are in operation with complete water years of streamflow data for computing various flow-duration discharges. For this study, partial-record sites were established along study-area streams where discharges were measured and used in record augmentation, and four continuous-record streamflow-gaging stations were selected as potential index stations.

\section{Partial-Record Sites}

Partial-record sites were established on 10 main streams and 5 tributary streams (table 3, figs. 1 and 5). Six of the streams were observed to be dry at the partial-record sites during the reconnaissance survey; these were Pāpua Gulch (a tributary of Honolua Stream), Honokahua Stream and its tributary Mokupe'a Gulch, Kahana Stream, and Wahikuli Gulch and its tributary Hāhākea Gulch. To evaluate whether these ephemeral streams are dry over the entire range of low-flow conditions, partial-record sites were established on these six streams. To characterize natural low-flow availability of the remaining nine streams with measurable flow, partial-record sites were established upstream from points of diversions. Discharges measured at the partial-record sites may include discharge from upstream development tunnels because flow from a development tunnel is considered water that would otherwise have naturally discharged into the stream.

For record augmentation, about 10 discharge measurements are generally made at a partial-record site during periods of low flow (Rantz and others, 1982). The discharge measurements should be made under a variety of low-flow conditions and during independent recessions. A streamflow recession is defined as the period when flows return to low-flow conditions following a period of direct runoff. Hydrographs from nearby active continuous-record streamflow-gaging stations were checked to determine when recessions were in place in the study-area streams. For this 
study, 10-13 discharge measurements were made at each of the partial-record sites (in streams with measurable low flow) between February 2012 and November 2013. A goal was to make discharge measurements that bracketed the range of flow-duration discharges, between $\mathrm{Q}_{95}$ and $\mathrm{Q}_{50}$, that are of interest in this study. This was done to increase the accuracy of the entire range of estimated flow-duration discharges at the partial-record sites. Discharge measurements were made with acoustic Doppler velocimeters and Price pygmy vertical-axis current meters, and are archived in the USGS National Water Information System database.

Most discharge measurements at the partial-record sites were made during stable-flow conditions, as documented by recording the height of water surface-commonly referred to as gage height or stage-during the time when the discharge measurements were being made. Discharge measurements that were made when the stage was highly variable were not used to estimate streamflow characteristics. A few measurements were made on days when the index station indicated a rise in streamflow at the end of the day or a rapid recession of streamflow in the beginning of the day, but relatively stable flow for a majority of the day. For these measurements, records at $\mathrm{Pu}$ 'u Kukui rain gage (fig. 1) were examined to evaluate the changes in streamflow. For cases in which discharge at the index station was affected by rainfall on the day when a discharge measurement was made at a partial-record site, the discharge measurement was included in the recordaugmentation analysis if (1) the rainfall occurred after the discharge measurement was made and discharge at the index station was steady for at least 18 hours during the day prior to rising, or (2) the rainfall occurred prior to the discharge measurement but discharge at the index station returned to a steady flow condition for at least 18 hours during the day following the rise. Discharge measurements made following a rainfall event and during streamflow recession were in some cases useful for estimating the higher low flows at the partial-record site. Representative concurrent daily mean discharges at the index station were computed from discharge during the part of the day (at least 18 continuous hours) with steady flow.

Table 3. Location of partial-record measurement sites established on the study-area streams, west Maui, Hawai'i.

[HI, Hawaii; ID, identifier; USGS, U.S. Geological Survey; abv, above; alt, altitude; bl, below; ft, feet; mi, mile; nr, near; US, upstream; database limitations preclude the use of Hawaiian diacritical marks in USGS station names]

\begin{tabular}{|c|c|c|c|c|c|}
\hline $\begin{array}{l}\text { Partial-record } \\
\text { site ID }\end{array}$ & $\begin{array}{l}\text { USGS station } \\
\text { number }\end{array}$ & $\begin{array}{c}\text { USGS station name, } \\
\text { Maui, } \mathrm{HI}\end{array}$ & $\begin{array}{l}\text { Altitude }^{a}, \\
\text { in feet }\end{array}$ & Latitude $^{b}$ & Longitude $^{b}$ \\
\hline L01 & 205856156370801 & Honolua Stream $40 \mathrm{ft}$ abv intake & 800 & $20^{\circ} 58^{\prime} 56.4^{\prime \prime}$ & $156^{\circ} 37^{\prime} 07.8^{\prime \prime}$ \\
\hline L03 & 205844156380501 & Honokahua Str $500 \mathrm{ft}$ abv Honokohau Ditch & 620 & $20^{\circ} 58^{\prime} 43.8^{\prime \prime}$ & $156^{\circ} 38^{\prime} 05.4^{\prime \prime}$ \\
\hline L04 & 205938156382201 & Mokupea Gulch at alt. $280 \mathrm{ft}$ & 280 & $20^{\circ} 59^{\prime} 38.4^{\prime \prime}$ & $156^{\circ} 38^{\prime} 21.6^{\prime \prime}$ \\
\hline L06 & 205554156370701 & Amalu Str $100 \mathrm{ft}$ abv intake & 1,620 & $20^{\circ} 55^{\prime} 53.5^{\prime \prime}$ & $156^{\circ} 37^{\prime} 06.8^{\prime \prime}$ \\
\hline L07 & 205545156371601 & Kapaloa Str $50 \mathrm{ft}$ abv intake & 1,560 & $20^{\circ} 55^{\prime} 45.4^{\prime \prime}$ & $156^{\circ} 37^{\prime} 16.2^{\prime \prime}$ \\
\hline L08 & 205511156393401 & Wahikuli Gulch $.2 \mathrm{mi}$ abv Honokohau Ditch & 800 & $20^{\circ} 55^{\prime} 11.0^{\prime \prime}$ & $156^{\circ} 39^{\prime} 34.2^{\prime \prime}$ \\
\hline L09 & 205455156394201 & Hahakea Gulch at $680 \mathrm{ft}$ & 680 & $20^{\circ} 54^{\prime} 54.7 "$ & $156^{\circ} 39^{\prime} 41.9^{\prime \prime}$ \\
\hline L13 & 205117156365201 & Launiupoko Stream $100 \mathrm{ft}$ abv intake & 1,340 & $20^{\circ} 51^{\prime} 16.6 "$ & $156^{\circ} 36^{\prime} 51.9^{\prime \prime}$ \\
\hline L14 & 205000156355801 & Olowalu Stream $800 \mathrm{ft}$ abv intake & 560 & $20^{\circ} 50^{\prime} 00.4^{\prime \prime}$ & $156^{\circ} 35^{\prime} 58.1^{\prime \prime}$ \\
\hline L15 & 16647000 & Ukumehame Gulch nr Olowalu & 410 & $20^{\circ} 49^{\prime} 09.3^{\prime \prime}$ & $156^{\circ} 35^{\prime} 00.6^{\prime \prime}$ \\
\hline
\end{tabular}

${ }^{a}$ Altitude values interpolated from USGS 1:24,000-scale digital hypsography data.

${ }^{b}$ Latitude and longitude coordinates in North American Datum of 1983. 

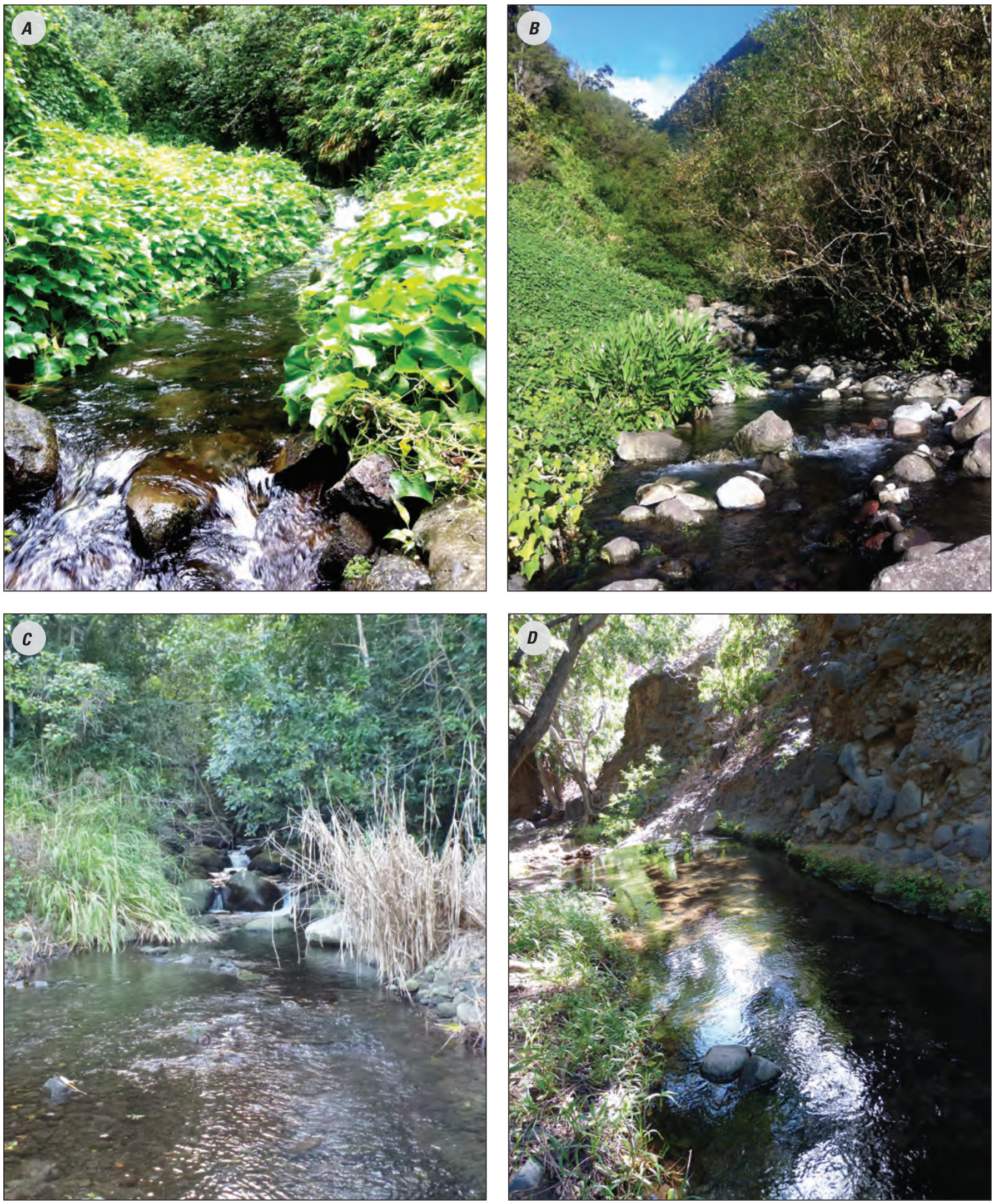

Figure 5. Photographs of study-area streams near the selected partial-record sites, west Maui, Hawai'i. A, Kapāloa Stream. B, Kahoma Stream. C, Kaua'ula Stream. D, Ukumehame Gulch. 


\section{Index Stations and Selection of Base Period}

An index station is a continuous-record streamflowgaging station that measures natural flow and has a sufficient length of record for estimating streamflow characteristics representative of long-term conditions. It is usually located along the same stream as the partial-record site or in a nearby stream valley that is hydrologically similar to the partial-record site. Searcy (1959, p. 14) defines hydrologic similarity between two drainage basins as the basins having the same probability of rainfall, but not necessarily the occurrence of concurrent rainfall. Proximity is a common criterion for selecting index stations, although remote index stations as far away as $50 \mathrm{mi}$ have been used to estimate streamflow characteristics (Searcy, 1959, p. 14). Four continuous-record stations that were in operation during the study period were selected as potential index stations that could be used to estimate low-flow characteristics for partial-record sites in the study-area streams. These index stations included station 16620000 on Honokōhau Stream, station 16614000 on Waihe 'e River, station 16604500 on 'T̄ao Stream, and station 16400000 on Hālawa Stream on the island of Moloka'i (fig. 1). Station 16618000 on Kahakuloa Stream, Maui, was not selected as a potential index station because the station was experiencing equipment malfunction during a majority of the study period.

During the study period, no continuous-record streamflow-gaging stations were operated within the study area. Additional flow information was needed to estimate streamflow characteristics; thus the partial-record site on Ukumehame Gulch (station 16647000, fig. 1) was designated as an index station because the site was easy to access, and it had a stable channel and control that would not be greatly affected by large storms. This provided an additional index station option if the partial-record sites did not correlate well with the other selected index stations. Streamflow was monitored at this site during the days that discharge measurements were being made in the study-area streams. To facilitate data collection, a stage-discharge relation (rating curve) was developed from a set of 13 paired discharge and stage measurements at the partial-record site. Using this relation, discharge at the partial-record site could be determined from a stage measurement without directly measuring the discharge. Stage measurements were taken every day (if time permitted) or every other day during a field-work week. Using rainfall records at $\mathrm{Pu}$ 'u Kukui rain gage (fig. 1) and stage measurements, general assumptions of streamflow patterns on Ukumehame Gulch were made to help understand flow conditions in other study-area streams.

Selection of a common period (base period) for adjusting streamflow records is critical to obtaining comparable lowflow estimates among the partial-record sites. Flow-duration discharges may vary when computed from different time periods because the distribution of streamflow is not constant with time (Ries, 1993, p. 18). When flow-duration discharges are estimated from multiple index stations with different time periods or record lengths, the time-sampling errors are generally larger than those computed with similar record periods. Therefore, streamflow records at index stations are commonly adjusted to a base period to minimize time-sampling errors, and to ensure that differences in flow characteristics are associated with spatial differences in climate and drainagebasin characteristics (Searcy, 1959, p. 12).

The base period should also be of sufficient length that is representative of long-term streamflow conditions. Fontaine (1996) used data from five long-term continuous-record streamflow-gaging stations on the island of $\mathrm{O}^{\prime}$ ahu, Hawai ' $\mathrm{i}$, each with more than 60 years of record, and demonstrated that estimates of streamflow characteristics were improved with increased record length (see figure 2 and table 9 in Fontaine, 1996). A minimum of 10 years of record is required to estimate certain streamflow characteristics such as the long-term median discharge. If the length of record is deemed inadequate for representing long-term conditions, record-augmentation techniques are commonly used to adjust the short-term record to a longer period (Ries, 1993, p. 18).

The 30-year period of water years 1984-2013 was selected as the base period for this study. This base period was selected on the basis of available data at stations 16604500 on 'Īao Stream and 16614000 on Waihe 'e River, which had the shortest periods of record out of the four index stations (table 4). The station on Honokōhau Stream had missing data in water years 1989 and 1990. Daily mean discharges for the missing records were estimated using the Maintenance of Variance Extension Type 1 (MOVE.1) record-augmentation technique. The procedures for MOVE.1 technique in estimating missing daily mean discharges are similar to those for estimating low-flow duration discharges at partial-record sites described in the next section of the report, under subheading "MOVE.1 Technique." Instead of low-flow duration discharges, daily mean discharges at index station 16614000 on Waihe "e River were used to estimate the concurrent daily mean discharges at the streamflow-gaging station on Honokōhau Stream during th e period of missing record. Flow-duration curves computed for the index stations using the base period are provided in figure 6.

Bassiouni and Oki (2013) analyzed trends in streamflow and base flow for long-term continuous-record stations in Hawai' $i$. Annual mean discharges and selected flow-duration discharges were analyzed in the study. Weak downward trends in base flow and low-streamflow characteristics were found during 1943-2008. The detected trends reflected regionwide changes in climatic and land-cover factors. Statistically significant (5 percent significance level) downward trends in low flows were not detected on Honokōhau Stream during 1943-2008; however, significant downward trends in low flows were detected on Hālawa Stream. The 30-year base period is adequate in representing the long-term streamflow conditions on Honokōhau Stream because significant trends were not detected and low-flow duration statistics computed from the base-period record are similar to those computed from the longer-term record (table 4). However, whether the 30-year base period is adequate in representing the long-term streamflow conditions on Hālawa Stream is less certain. 


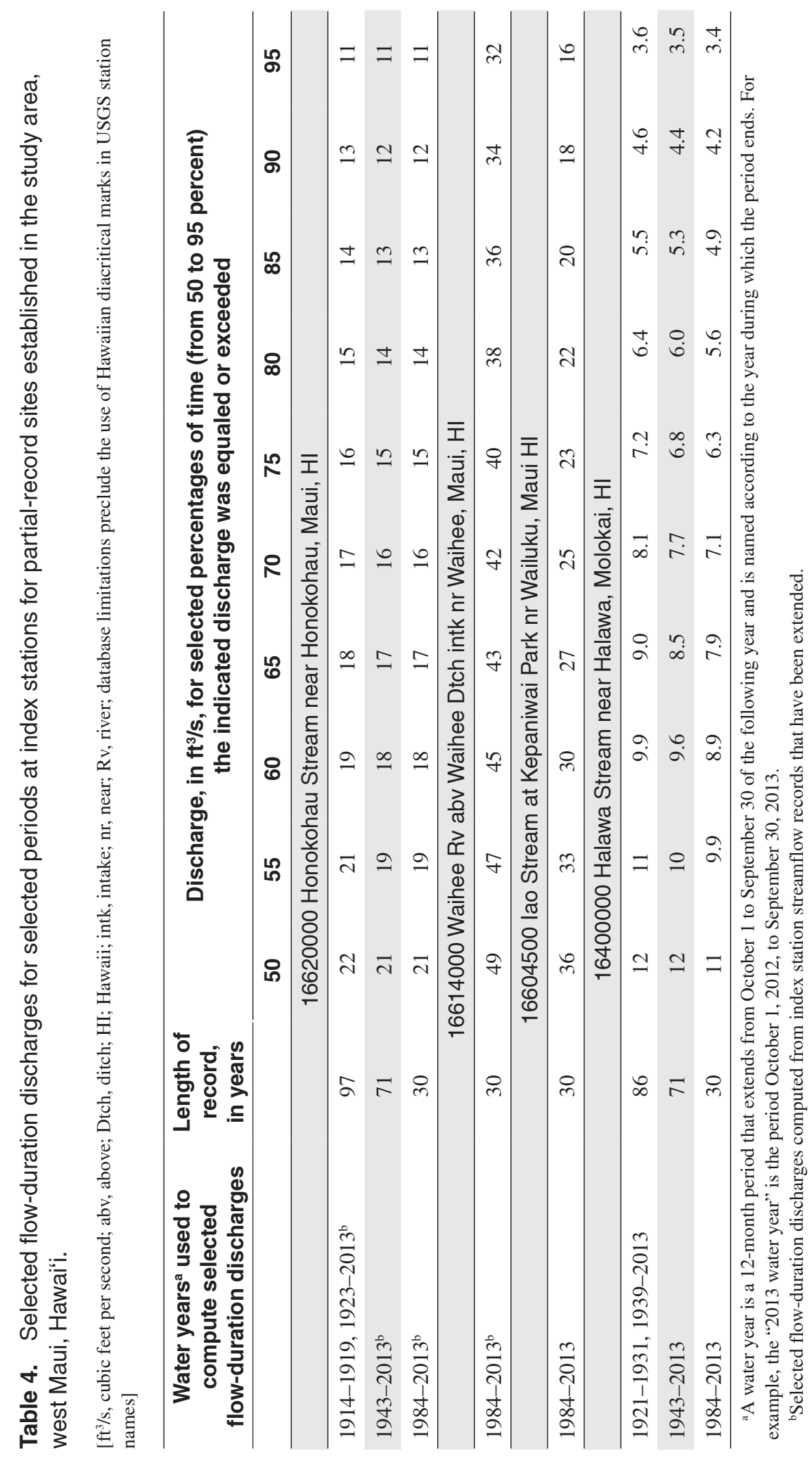



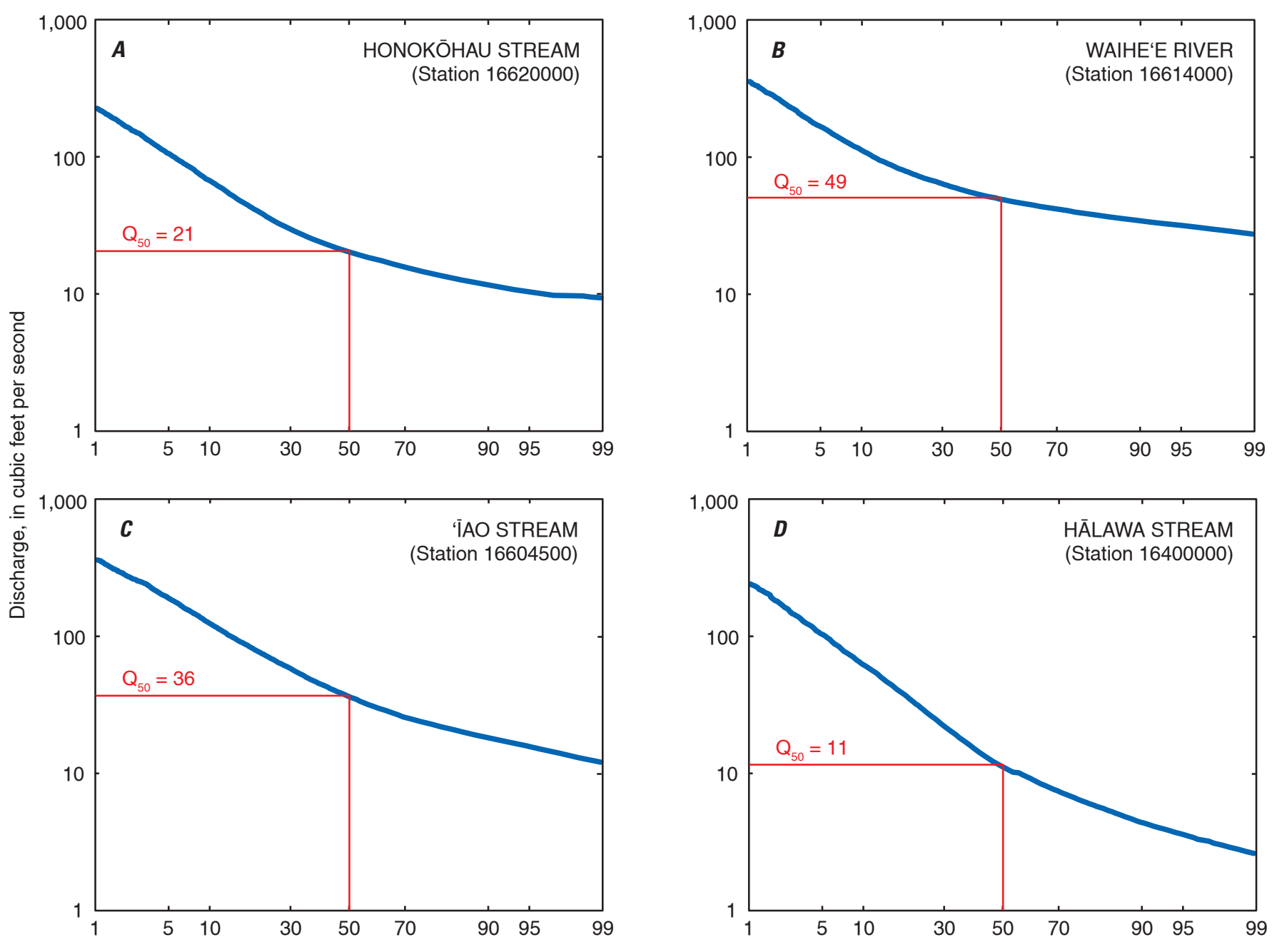

Percentage of time indicated discharge was equaled or exceeded

\section{EXPLANATION}

$Q_{50}, 50$-percent duration discharge, in cubic feet per second

Figure 6. Plots showing flow-duration curves for total flow at index stations for base period 1984-2013. A, Index station 1662000 on Honokōhau Stream, Maui, Hawai'i. B, Index station 16614000 on Waihe'e River, Maui, Hawai'i. C, Index station 16604500 on 'lao Stream, Maui, Hawai'i. D, Index station 16400000 on Hālawa Stream, Moloka'i, Hawai'i.

\section{Record-Augmentation Techniques}

Two techniques were used to extend streamflow records for this study: (1) the graphical-correlation technique described by Searcy (1959, p. 14), and (2) the MOVE.1 technique described by Hirsch (1982). Both record-augmentation techniques assume that the relation between concurrent records at the index and partial-record site is the same for any time period (Ries, 1993, p.21). Selecting the appropriate record-augmentation technique for estimating streamflow characteristics depends on the relation between discharge measurements made at the partial-record site and the concurrent daily mean discharges at the index station. The initial procedures used prior to the application of recordaugmentation techniques are as follows:
1. The 95-, 90-, 85-, 80-, 75-, 70-, 65-, 60-, 55-, and 50-percent flow-duration discharges were computed for the base period of 1984-2013 at selected index stations (table 4).

2. Base-10 logarithms of discharges measured at the partial-record sites and concurrent daily mean discharges at each of the selected index stations were plotted to determine which index station provided the best relation. Correlation coefficients were determined for each relation. Only index stations with correlation coefficients greater than 0.8 were considered for use in record augmentation for the partial-record site. 
3. Plots developed in step 2 were used to assess curvature in the relation between the discharges at the partial-record site and index station. When little or no curvature was detected in the relation on a logarithmic plot, the MOVE. 1 technique was used to estimate flow-duration discharges. When curvature was evident in the relation, the graphical-correlation technique was used.

\section{Graphical-Correlation Technique}

In the graphical-correlation record-augmentation technique, a curve-of-relation is plotted through the discharges measured at the partial-record site and concurrent daily mean discharges at the index station. The discharges are plotted on an arithmetic scale when drawing the curve-of-relation to reduce curvature in the extreme low flows and to avoid long downward extrapolations of the data (Ries, 1993, p.21). The selected low-flow duration discharges at the partial-record site are determined by reading the discharges of the partial-record site from the best fit curve-of-relation that correspond to the low-flow duration discharges at the index station.

\section{MOVE.1 Technique}

The statistical relation developed with the MOVE.1 technique is based on the line of organic correlation regression method. Hirsch and Gilroy (1984) and Helsel and Hirsch (2002) showed that the line of organic correlation method was most appropriate in record augmentation compared with ordinary least squares and least normal squares regression methods. The general procedure for the MOVE.1 technique begins with the transformation of concurrent discharges at the index station and partial-record site to base-10 logarithms, and then computation of the means and standard deviations of the transformed values. The low-flow duration discharges for the base period at the index station are also computed and transformed to base-10 logarithms. Estimates of low-flow duration discharges at the partial-record sites are determined using the MOVE. 1 formula (equation 2) and then converted to the original (nontransformed) units of measurement in $\mathrm{ft}^{3} / \mathrm{s}$.

$$
Y_{i}=m_{y}+\frac{S_{y}}{S_{x}}\left(X_{i}-m_{x}\right),
$$

where

$$
\begin{array}{cl}
Y_{i} \quad \begin{array}{l}
\text { is the base-10 logarithm of the estimated } \\
\text { low-flow duration discharge at the partial- } \\
\text { record site; }
\end{array} \\
\begin{array}{c}
X_{i} \\
\text { is the base-10 logarithm of the computed } \\
\text { low-flow duration discharge at the index } \\
\text { station; }
\end{array} \\
\begin{aligned}
m_{y} \quad \text { is the mean of the base-10 logarithms of the } \\
\text { discharge measurements at the partial- } \\
\text { record site; }
\end{aligned}
\end{array}
$$

\author{
$m_{x} \quad$ is the mean of the base- 10 logarithms of the \\ concurrent daily mean discharges at the \\ index station; \\ $s_{y} \quad$ is the standard deviation of the base- 10 \\ logarithms of the discharge measurements \\ at the partial-record site; and \\ $s_{x} \quad$ is the standard deviation of the base- 10 \\ logarithms of the concurrent daily mean \\ discharges at the index station.
}

Granato (2009) developed the Streamflow Record Extension Facilitator program to automate the MOVE.1 technique. The program was used in this study to facilitate record augmentation. MOVE. 1 results were evaluated by analyzing several regression statistics computed by the program. Those statistics included the correlation coefficient $(r)$, residual error for each data point $\left(e_{i}\right)$, the leverage of each data point $\left(h_{i}\right)$, the mean square error (MSE), the root mean square error (RMSE), and a modified Nash-Sutcliff coefficient of efficiency $(E)$.

The correlation coefficient (Vogel and Stedinger, 1985; Helsel and Hirsch, 2002) measures the strength of the linear relation between concurrent discharges at the index station and partial-record site. The residual error is the uncertainty in the estimated flow-duration discharges at the partial-record sites. The leverage of a data point reflects the influence it has on the statistical relation. A high leverage likely indicates an outlier in the discharge measurements made at the partial-record sites and the statistical relation would be skewed towards this data point. The root mean square error (or standard deviation) is the square root of the variance, and it aggregates the differences (or residuals) between individual estimated and measured discharges at the partial-record sites into a single predictive measure. The modified Nash-Sutcliff coefficient of efficiency (Legates and McCabe, 1999), with values ranging from negative infinity to 1 , determines the accuracy to which the statistical relation predicts low-flow duration discharges at the partial-record sites from the low-flow duration discharges at the index station. A coefficient of efficiency of zero indicates that the measured discharges at the partial-record site is as accurate for predicting flow-duration discharges as the regression model. A negative coefficient of efficiency occurs when the mean of measured discharges at the partial-record site is a better predictor than the regression model. The equations used to compute these regression statistics can be found in Granato (2009).

\section{Results and Discussion}

\section{Natural Low-Flow Duration Discharges}

Low-flow duration discharges for partial-record sites on Honolua and Kahoma Streams were estimated using the graphical-correlation technique. Low-flow duration discharges for partial-record sites on Honokōwai, Kanahā, Kaua 'ula, 
Launiupoko, and Olowalu Streams, and Ukumehame Gulch were estimated using the MOVE.1 technique. In the following discussion, the partial-record site identifier (ID) is used instead of the USGS station number (table 3). The index stations used, record-augmentation techniques applied, and selected regression statistics computed for the flow-duration discharge estimates at partial-record sites in the study-area streams are summarized in table 5. Selected natural flow-duration discharge estimates at the partial-record sites are listed in table 6 .

\section{Flow-Duration Discharges Estimated Using the Graphical Correlation Technique}

\section{Honolua Stream}

Nine of ten discharge measurements made at partialrecord site L01 on Honolua Stream (fig. 1) as part of this study and previous measurements made on June 22, 1967, and May 13, 2008, were used to estimate flow-duration discharges for Honolua Stream (table 7). Low-flow duration discharges estimated with the graphical-correlation technique range from zero flow $\left(\mathrm{Q}_{90}\right.$ and $\mathrm{Q}_{95}$ discharges $)$ to $3.8 \mathrm{ft}^{3} / \mathrm{s}\left(\mathrm{Q}_{50}\right.$ discharge $)$. Although Honolua Stream at the partial-record site was not observed to be dry during the study period, the stream was estimated to be dry at least 10 percent of the time based on the graphical correlation of the data collected. A curvilinear trend provides the best fit to the plot of measured discharges at the partial-record site on Honolua Stream and concurrent daily mean discharges at the index station on Honokōhau Stream (fig. 7A). The plot also shows that the discharge measured on July 26, 2012, is an outlier, but the measurement was included in the analysis because the discharge was measured during stable-flow conditions. A majority of the discharge measurements used for record augmentation at the partial-record site generally are between the $\mathrm{Q}_{85}$ and $\mathrm{Q}_{50}$ duration discharges; therefore, the flow-duration estimates are considered to be representative of low-flow conditions on Honolua Stream.

\section{Kahoma Stream}

At partial-record site L10 on Kahoma Stream (fig. 1), 17 discharge measurements were made as part of this study; 10 of those were used to estimate flow-duration discharges for Kahoma Stream (table 8). The curve-of-relation between measured discharges at the partial-record site on Kahoma Stream and concurrent daily mean discharges at the index station on Honokōhau Stream (fig. 7B) indicates that the low-flow duration discharge estimates range from $2.0 \mathrm{ft}^{3} / \mathrm{s}\left(\mathrm{Q}_{95}\right.$ discharge $)$ to $5.8 \mathrm{ft}^{3} / \mathrm{s}\left(\mathrm{Q}_{50}\right.$ discharge) (table 6). Most of the discharge measurements used for record augmentation at the partial-record site are between the $\mathrm{Q}_{95}$ and $\mathrm{Q}_{50}$ duration discharges; therefore, the flow-duration estimates are considered to be representative of the low-flow conditions on Kahoma Stream.

Table 5. Summary of regression equations and selected regression statistics for partial-record sites in the study-area streams, west Maui, Hawai'i.

[-, not applicable; E, modified Nash-Sutcliff coefficient of efficiency; ID, identifier; r, correlation coefficient; MOVE.1, Maintenance of Variance Extension Type 1; RMSE, root mean square error; SREF, Streamflow Record Extension Facilitator program; $X_{i}$, base-10 logarithm of the computed low-flow duration discharge at the index station; $Y_{i}$, base-10 logarithm of the estimated low-flow duration discharge at the partial record site]

\begin{tabular}{|c|c|c|c|c|c|c|}
\hline \multirow{2}{*}{$\begin{array}{l}\text { Partial-record site } \text { ID }^{\mathrm{a}} \\
\text { and stream name }\end{array}$} & \multirow{2}{*}{$\begin{array}{l}\text { Index station ID } \\
\text { and stream name }\end{array}$} & \multirow{2}{*}{$\begin{array}{l}\text { Record- } \\
\text { augmentation } \\
\text { technique }\end{array}$} & \multirow{2}{*}{$\begin{array}{c}\text { MOVE. } 1 \text { regression } \\
\text { equation }\end{array}$} & \multicolumn{3}{|c|}{$\begin{array}{l}\text { Regression statistics } \\
\text { generated from SREF }\end{array}$} \\
\hline & & & & $\mathbf{r}$ & RMSE & $E$ \\
\hline L01 Honolua Stream & 16620000 Honokōhau Stream & Graphical & - & - & - & - \\
\hline $\begin{array}{l}\text { L06 + L07 Honokōwai } \\
\text { Stream }^{\text {b }}\end{array}$ & 16620000 Honokōhau Stream & MOVE.1 & $Y_{i}=0.64+0.73\left(X_{i}-1.20\right)$ & 0.88 & 0.035 & 0.42 \\
\hline L10 Kahoma Stream & 16620000 Honokōhau Stream & Graphical & - & - & - & - \\
\hline L11 Kanahā Stream & 16400000 Hālawa Stream & MOVE.1 & $Y_{i}=0.65+0.17\left(X_{i}-0.81\right)$ & 0.90 & 0.020 & 0.52 \\
\hline L12 Kaua'ula Stream & 16620000 Honokōhau Stream & MOVE.1 & $Y_{i}=0.84+1.06\left(X_{i}-1.19\right)$ & 0.85 & 0.069 & 0.38 \\
\hline L13 Launiupoko Stream & 16647000 Ukumehame Gulch & MOVE.1 & $Y_{i}=-0.30+0.65\left(X_{i}-0.74\right)$ & 0.90 & 0.060 & 0.55 \\
\hline L14 Olowalu Stream & 16604500 ‘'̄ao Stream & MOVE.1 & $Y_{i}=0.66+0.85\left(X_{i}-1.41\right)$ & 0.96 & 0.049 & 0.69 \\
\hline L15 Ukumehame Gulch & 16604500 ‘'̄ao Stream & MOVE.1 & $Y_{i}=0.65+0.64\left(X_{i}-1.48\right)$ & 0.94 & 0.066 & 0.66 \\
\hline
\end{tabular}

${ }^{a}$ Refer to figure 1 for locations of the stations and table 3 for the U.S. Geological Survey station number and name associated with each partial-record site ID.

${ }^{\text {b} F l o w-d u r a t i o n ~ d i s c h a r g e s ~ o n ~ H o n o k o ̄ w a i ~ S t r e a m ~ a t ~ t h e ~ c o n f l u e n c e ~ o f ~ A m a l u ~ a n d ~ K a p a ̄ l o a ~ S t r e a m s ~ w e r e ~ e s t i m a t e d ~ u s i n g ~ c o m b i n e d ~ d i s c h a r g e s ~ m e a s u r e d ~ a t ~}$ partial-record sites on Amalu and Kapāloa Streams during May 2012-August 2013. 
Table 6. Selected natural-flow duration discharge estimates at partial-record sites in the study-area streams, west Maui, Hawaili, for base period 1984-2013.

$\left[\mathrm{ft}^{3} / \mathrm{s}\right.$, cubic feet per second; ID, identifier]

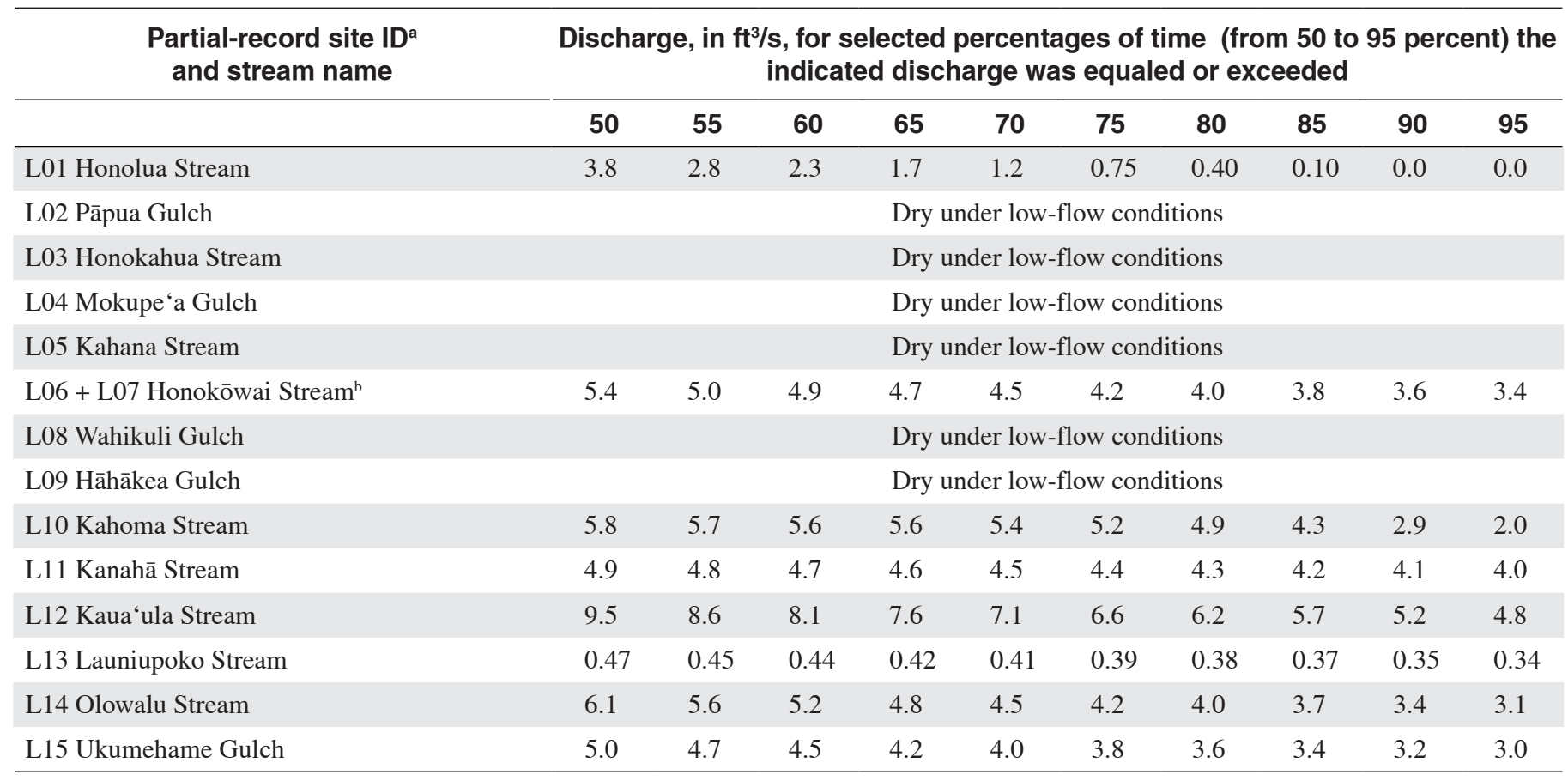

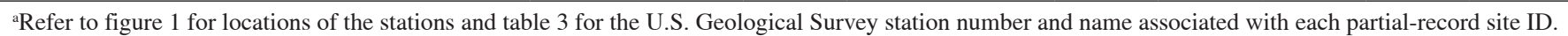

${ }^{b}$ Flow-duration discharges at Honokōwai Stream immediately downstream from the confluence of Amalu and Kapāloa Streams were estimated using combined discharges measured at partial-record sites on Amalu and Kapāloa Streams during study period.

Table 7. Measured discharges at partial-record site 205856156370801 on Honolua Stream and concurrent daily mean discharges at streamflow-gaging station (index station) 16620000 on Honokōhau Stream, west Maui, Hawai'i.

[ $\mathrm{ft}^{3} / \mathrm{s}$, cubic feet per second; -, not available; measured discharge not used in record augmentation is underlined]

\begin{tabular}{lcc}
\hline Date & $\begin{array}{c}\text { Daily mean discharge in } \mathbf{f t}^{3} / \mathbf{s} \\
\text { on Honokōhau Stream }\end{array}$ & $\begin{array}{c}\text { Measured discharges in } \mathrm{ft}^{3} / \mathbf{s} \\
\text { on Honolua Stream }\end{array}$ \\
\hline $12 / 22 / 1920$ & - & ${\underline{0.95^{\mathrm{b}}}}^{\mathrm{b}}$ \\
\hline $08 / 09 / 1921$ & - & $\underline{1.1}^{\mathrm{b}}$ \\
\hline $06 / 22 / 1967$ & 15 & 0.36 \\
\hline $05 / 13 / 2008$ & 14 & 0.43 \\
\hline $02 / 07 / 2012$ & 39 & $\underline{0.76^{\mathrm{c}}}$ \\
\hline $06 / 27 / 2012$ & $18^{\mathrm{a}}$ & 2.48 \\
\hline $06 / 29 / 2012$ & 25 & 4.83 \\
\hline $07 / 26 / 2012$ & 14 & 1.84 \\
\hline $08 / 24 / 2012$ & 20 & 3.16 \\
\hline $09 / 11 / 2012$ & 18 & 2.00 \\
\hline $10 / 10 / 2012$ & $14^{\mathrm{a}}$ & 0.97 \\
\hline $11 / 08 / 2012$ & 16 & 0.65 \\
\hline $12 / 10 / 2012$ & 13 & 0.11 \\
\hline $04 / 16 / 2013$ & 13 & 0.47 \\
\hline
\end{tabular}

${ }^{a}$ Daily mean discharge computed from partial record of flow, 20 continuous hours or more in a 24-hour period.

${ }^{b}$ Discharge not used in record augmentation because concurrent daily mean discharge at the index station was unavailable.

'Discharge not used in record augmentation because the hydrograph from the index station indicated highly variable flows during the time the measurement was made. 

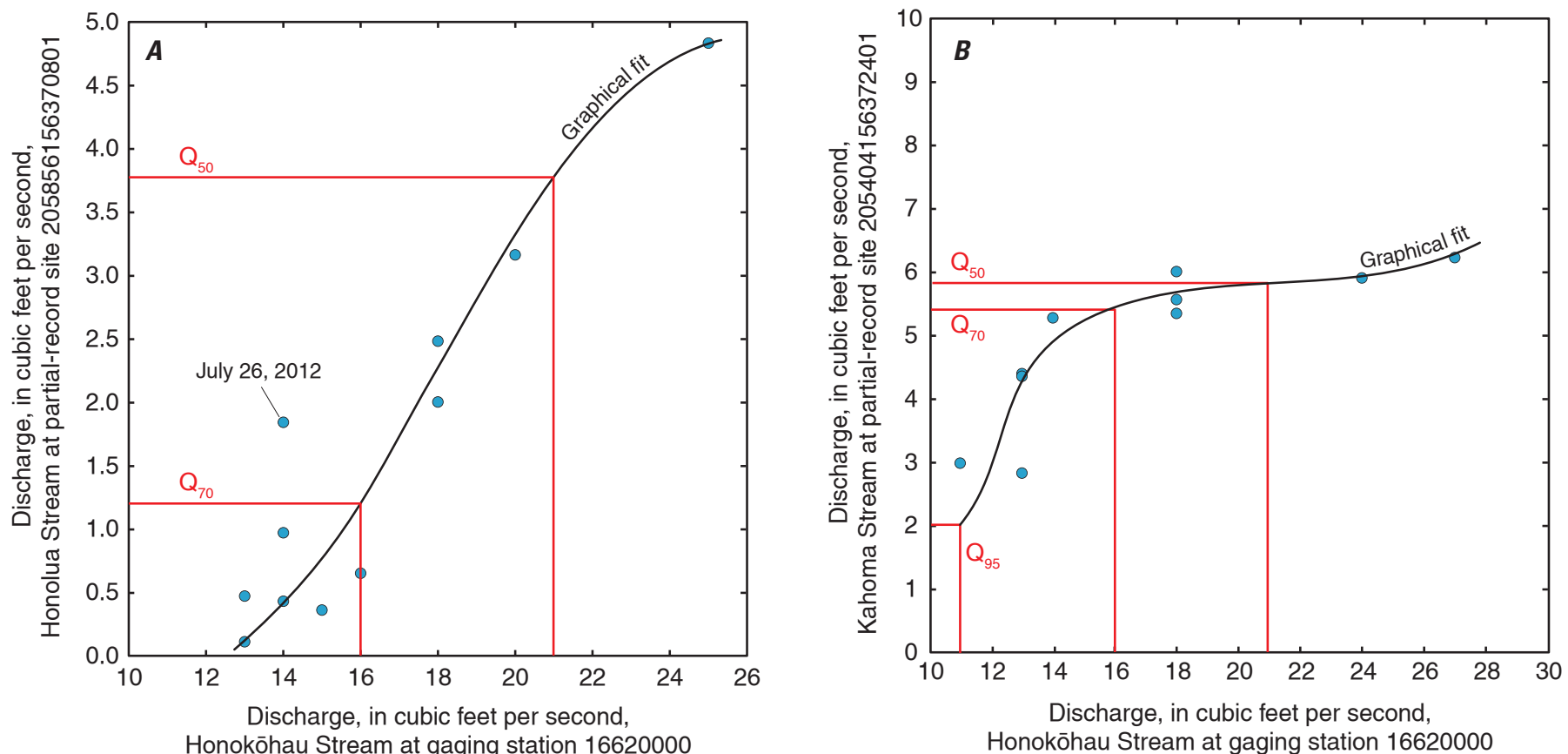

Figure 7. Plots showing relation between measured discharges at partial-record sites and concurrent daily mean discharges at index station 16620000 on Honokōhau Stream, Maui, Hawai'i. A, Partial-record site 205856156370801 on Honolua Stream. B, Partial-record site 205404156372401 on Kahoma Stream.

Table 8. Measured discharges at partial-record site 205404156372401 on Kahoma Stream and concurrent daily mean discharges at streamflow-gaging station (index station) 16620000 on Honokōhau Stream, west Maui, Hawai'i.

[ $\mathrm{ft}^{3} / \mathrm{s}$, cubic feet per second; measured discharge not used in record augmentation is underlined]

\begin{tabular}{|c|c|c|}
\hline Date & $\begin{array}{l}\text { Daily mean discharge in } \mathrm{ft}^{3} / \mathrm{s} \\
\text { on Honokōhau Stream }\end{array}$ & $\begin{array}{c}\text { Measured discharges in } \mathrm{ft}^{3} / \mathrm{s} \\
\text { on Kahoma Stream }\end{array}$ \\
\hline $02 / 09 / 2012$ & 11 & 2.98 \\
\hline 03/20/2012 & 13 & 4.39 \\
\hline 05/01/2012 & 21 & $\underline{5.25^{\mathrm{b}}}$ \\
\hline 06/05/2012 & 29 & $\underline{3.93^{\mathrm{b}}}$ \\
\hline $06 / 26 / 2012$ & 33 & ${\underline{12.9^{\mathrm{b}}}}$ \\
\hline $07 / 24 / 2012$ & 22 & ${\underline{4.97^{\mathrm{b}}}}$ \\
\hline $08 / 22 / 2012$ & $18^{\mathrm{a}}$ & 6.00 \\
\hline 09/13/2012 & 25 & $11.2^{\mathrm{c}}$ \\
\hline 09/13/2012 & 25 & $\underline{10.2^{\mathrm{c}}}$ \\
\hline 09/13/2012 & 25 & ${\underline{9.36^{c}}}^{\mathrm{c}}$ \\
\hline $10 / 11 / 2012$ & 18 & 5.34 \\
\hline $11 / 07 / 2012$ & $14^{\mathrm{a}}$ & 5.27 \\
\hline $12 / 12 / 2012$ & 13 & 4.35 \\
\hline $01 / 15 / 2013$ & 18 & 5.55 \\
\hline $02 / 12 / 2013$ & $24^{\mathrm{a}}$ & 5.90 \\
\hline $05 / 14 / 2013$ & 27 & 6.22 \\
\hline $11 / 18 / 2013$ & 13 & 2.81 \\
\hline
\end{tabular}

a Daily mean discharge computed from partial record of flow, 19 continuous hours or more in a 24-hour period.

${ }^{b}$ Discharge not used in record augmentation because the hydrograph from the index station indicated highly variable flows during the time the measurement was made.

'Discharge made during a rapid recession of streamflow on the same day and was not used in record augmentation. 


\section{Flow-Duration Discharges Estimated Using the MOVE.1 Technique}

\section{Honokōwai Stream}

Flow-duration discharges on Honokōwai Stream at the confluence of Amalu and Kapāloa Streams were estimated using combined discharges measured at partial-record sites on Amalu (site L06) and Kapāloa (site L07) Streams (fig. 1). A set of 14 measurements was made as part of this study and 10 sets of measurements were used in record augmentation (table 9). The MOVE.1 relation between combined measured discharges at the partial-record sites and concurrent daily mean discharges at the index station has a correlation coefficient $(r)$ of 0.88 . Estimated low-flow duration discharges range from $3.4 \mathrm{ft}^{3} / \mathrm{s}\left(\mathrm{Q}_{95}\right.$ discharge $)$ to $5.4 \mathrm{ft}^{3} / \mathrm{s}\left(\mathrm{Q}_{50}\right.$ discharge $)$ (table 6). These estimates assume minimal losses or gains in Amalu and Kapāloa Streams between the partial-record sites and the confluence of the tributaries. Combined discharges at the partial-record sites used for record augmentation generally are between the $\mathrm{Q}_{95}$ and $\mathrm{Q}_{50}$ duration discharges; therefore, the flow-duration estimates are considered to be representative of the low-flow conditions on Honokōwai Stream.

Table 9. Combined discharges measured at partial-record sites 205554156370701 on Amalu Stream and 205545156371601 on Kapāloa Stream, and concurrent daily mean discharges at streamflow-gaging station (index station) 16620000 on Honokōhau Stream, west Maui, Hawai'i.

$\left[\mathrm{ft}^{3} / \mathrm{s}\right.$, cubic feet per second; -, not available; measured discharge not used in record augmentation is $\underline{\text { underlined] }}$

\begin{tabular}{|c|c|c|c|c|}
\hline \multirow{2}{*}{ Date } & \multirow{2}{*}{$\begin{array}{c}\text { Daily mean discharge } \\
\text { in } \mathrm{ft}^{3} / \mathrm{s} \text { on } \\
\text { Honokōhau Stream }\end{array}$} & \multicolumn{3}{|c|}{ Measured discharges in $\mathrm{ft}^{3} / \mathrm{s}$} \\
\hline & & Amalu Stream & Kapāloa Stream & Combined $^{\mathrm{a}}$ \\
\hline 08/04/1911 & - & - & - & $\underline{0.16^{c}}$ \\
\hline $10 / 17 / 1911$ & - & $\underline{2.07^{\mathrm{c}}}$ & - & - \\
\hline $05 / 02 / 2012$ & 20 & $\underline{1.01}$ & $\underline{4.84}$ & ${\underline{5.85^{\mathrm{d}}}}^{-}$ \\
\hline 06/06/2012 & 23 & 1.33 & 4.73 & 6.06 \\
\hline $06 / 27 / 2012$ & $18^{\mathrm{b}}$ & 0.37 & 4.67 & 5.04 \\
\hline $07 / 25 / 2012$ & 17 & 0.32 & 4.13 & 4.45 \\
\hline 09/11/2012 & 18 & 0.61 & 3.93 & 4.54 \\
\hline $10 / 10 / 2012$ & $14^{\mathrm{b}}$ & 0.00 & 4.30 & 4.30 \\
\hline $11 / 08 / 2012$ & 16 & $\underline{0.54}$ & $\underline{5.30}$ & $\underline{5.84}^{\mathrm{d}}$ \\
\hline $12 / 11 / 2012$ & 12 & 0.00 & 4.18 & 4.18 \\
\hline $03 / 13 / 2013$ & 13 & 0.082 & 3.66 & 3.74 \\
\hline $04 / 16 / 2013$ & 13 & 0.00 & 3.48 & 3.48 \\
\hline $05 / 15 / 2013$ & 19 & 0.37 & 4.31 & 4.68 \\
\hline 06/04/2013 & 14 & 0.24 & 3.93 & 4.17 \\
\hline $06 / 26 / 2013$ & 58 & $\underline{1.85}$ & $\underline{5.29}$ & ${\underline{7.14^{\mathrm{d}}}}^{-}$ \\
\hline 08/30/2013 & 56 & $\underline{0.00}$ & $\underline{3.46}$ & ${\underline{3.46^{\mathrm{d}}}}^{\mathrm{d}}$ \\
\hline
\end{tabular}

${ }^{a}$ Combined values represent the total discharge of Honokōwai Stream at the confluence of Amalu and Kapāloa Streams, where the former

U.S. Geological Survey continuous-record streamflow-gaging station 16630000 was located.

'Daily mean discharge computed from partial record of flow, 20 continuous hours or more in a 24-hour period.

'Discharge not used in record augmentation because concurrent daily mean discharge at the index station was unavailable.

${ }^{\mathrm{d}}$ Discharge not used in record augmentation because the hydrograph from the index station indicated highly variable flows during the time the measurement was made. 


\section{Kanahā Stream}

A total of 14 measurements were made at partial-record site L11 on Kanahā Stream (fig. 1) and 8 of these measurements were used to estimate flow-duration discharges for Kanahā Stream (table 10). The measurement made on June 3, 2013, was not used because it appeared to be an outlier that greatly deviated from the general trend that was consistent with the eight measurements used for record augmentation. The MOVE. 1 relation between measured discharges at the partial-record site and concurrent daily mean discharges at the index station has a correlation coefficient of 0.90 . Estimated low-flow duration discharges range from $4.0 \mathrm{ft}^{3} / \mathrm{s}$ $\left(\mathrm{Q}_{95}\right.$ discharge $)$ to $4.9 \mathrm{ft}^{3} / \mathrm{s}\left(\mathrm{Q}_{50}\right.$ discharge $)$. Based on these results, flow at the partial-record site on Kanahā Stream does not vary greatly under low-flow conditions. Most of the discharge measurements used for record augmentation at the partial-record site are between the $\mathrm{Q}_{95}$ and $\mathrm{Q}_{50}$ duration discharges; therefore, the flow-duration estimates are considered to be representative of the low-flow conditions on Kanahā Stream.

Table 10. Measured discharges at partial-record site 205334156382201 on Kanahā Stream and concurrent daily mean discharges at streamflow-gaging station (index station) 16400000 on Hālawa Stream, Moloka'i, Hawai'i.

$\left[\mathrm{ft}^{3} / \mathrm{s}\right.$, cubic feet per second; measured discharge not used in record augmentation is underlined]

\begin{tabular}{|c|c|c|}
\hline Date & $\begin{array}{c}\text { Daily mean discharge in } \mathrm{ft}^{3} / \mathrm{s} \\
\text { on Hālawa Stream }\end{array}$ & $\begin{array}{l}\text { Measured discharges in } \mathrm{ft}^{3} / \mathrm{s} \\
\text { on Kanahā Stream }\end{array}$ \\
\hline $02 / 06 / 2012$ & 9.4 & $\underline{3.51}^{\mathrm{b}}$ \\
\hline 03/19/2012 & 36 & $\underline{3.83}^{\mathrm{b}}$ \\
\hline 06/04/2012 & 4.4 & 4.35 \\
\hline $07 / 23 / 2012$ & 10 & 4.51 \\
\hline 09/10/2012 & $15^{\mathrm{a}}$ & 5.13 \\
\hline $10 / 09 / 2012$ & 4.6 & 4.31 \\
\hline $11 / 05 / 2012$ & 3.8 & 3.97 \\
\hline $01 / 14 / 2013$ & $12^{\mathrm{a}}$ & 5.12 \\
\hline $02 / 11 / 2013$ & 44 & ${\underline{6.20^{\mathrm{b}}}}^{\mathrm{b}}$ \\
\hline $02 / 14 / 2013$ & 6.6 & 4.21 \\
\hline $04 / 15 / 2013$ & 3.4 & 4.13 \\
\hline $06 / 03 / 2013$ & 20 & $\underline{3.42^{\mathrm{c}}}$ \\
\hline $06 / 24 / 2013$ & 25 & $\underline{4.44}^{\mathrm{b}}$ \\
\hline $08 / 29 / 2013$ & 5.2 & $2.78^{\mathrm{b}}$ \\
\hline
\end{tabular}

a Daily mean discharge computed from partial record of flow, 18 continuous hours or more in a 24-hour period.

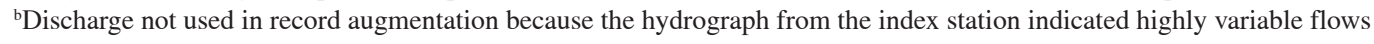
during the time the measurement was made.

'Discharge not used in record augmentation because it appeared to be an outlier that greatly deviated from the general trend that was consistent with the eight measurements used for record augmentation. 


\section{Kaua'ula Stream}

Eleven of 15 discharge measurements made at partialrecord site L12 on Kaua 'ula Stream (fig. 1) as part of this study, and a previous measurement made on September 17, 2008, were used to estimate flow-duration discharges for Kaua 'ula Stream (table 11). The two previous measurements from 2008 were made at station 16643000 in Kaua “ula Ditch and captured all of the flow in the stream; therefore, the discharges are representative of natural-flow conditions upstream from the ditch intake. Because these measurements were made during the same streamflow recession, only one of the measurements was used in record augmentation. The MOVE.1 relation between measured discharges at the partial-record site and concurrent daily mean discharges at the index station has a correlation coefficient of 0.85 . Estimated low-flow duration discharges range from $4.8 \mathrm{ft}^{3} / \mathrm{s}\left(\mathrm{Q}_{95}\right.$ discharge $)$ to $9.5 \mathrm{ft}^{3} / \mathrm{s}$ $\left(\mathrm{Q}_{50}\right.$ discharge $)$. Most of the discharge measurements used for record augmentation at the partial-record site are between the $\mathrm{Q}_{95}$ and $\mathrm{Q}_{50}$ duration discharges; therefore, the flow-duration estimates are considered to be representative of the low-flow conditions on Kaua'ula Stream.

Table 11. Measured discharges at partial-record site 205239156372101 on Kaua'ula Stream and concurrent daily mean discharges at streamflow-gaging station (index station) 16620000 on Honokōhau Stream, west Maui, Hawai'i.

[ $\mathrm{ft}^{3} / \mathrm{s}$, cubic feet per second; measured discharge not used in record augmentation is underlined]

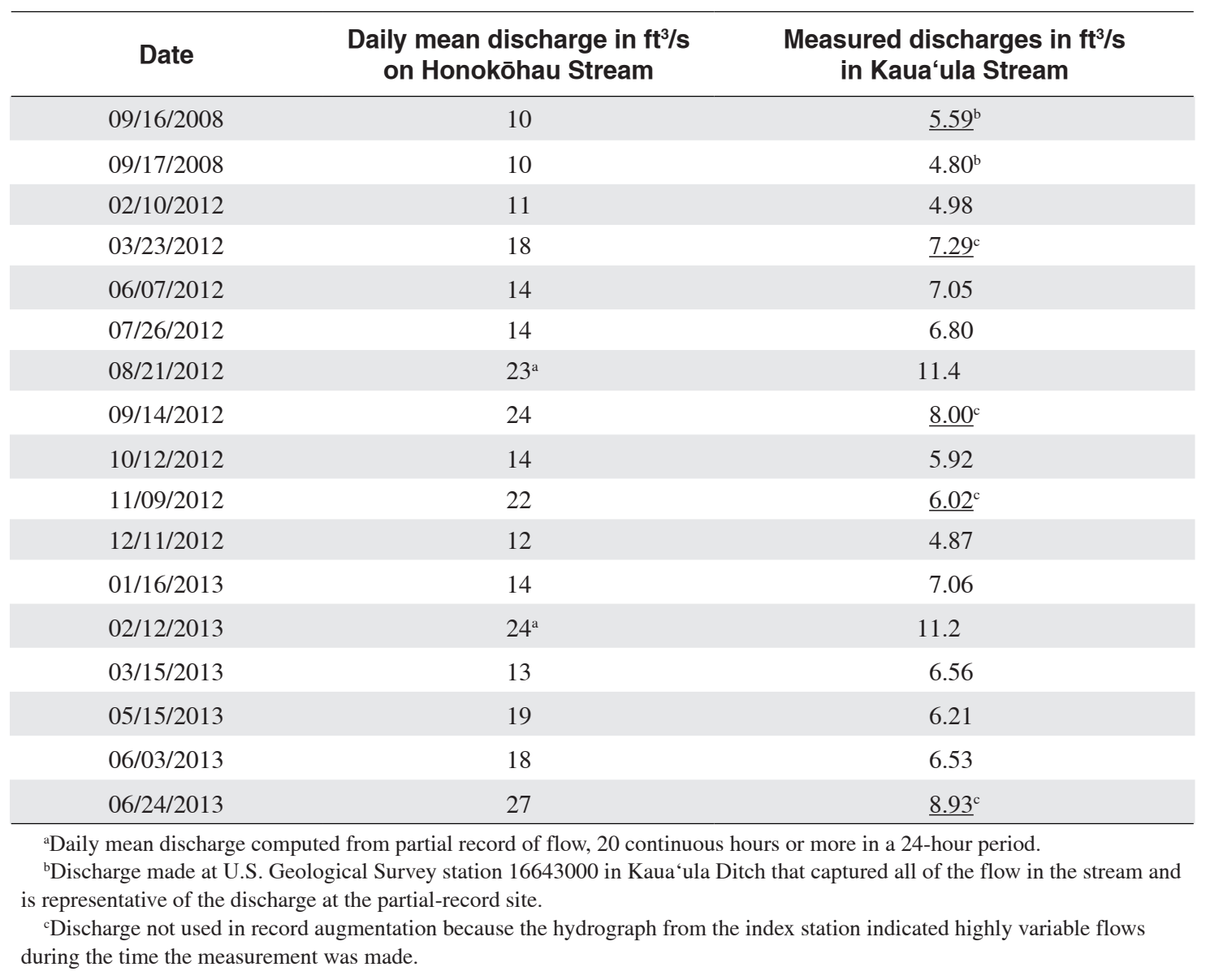




\section{Launiupoko Stream}

Partial-record site L15 on Ukumehame Gulch was selected as the index station for partial-record site L13 on Launiupoko Stream because no other continuous-record stations that were in operation during the study period correlated well with the discharges of Launiupoko Stream (fig. 1). Ten of thirteen discharge measurements collected as part of this study were used to estimate flow-duration discharges (table 12). Although no direct measurement was made at the Ukumehame Gulch partial-record site on March 20, 2012, the discharge was assumed to be the same as the discharge on March $19\left(5.11 \mathrm{ft}^{3} / \mathrm{s}\right)$ because rainfall records at $\mathrm{Pu}$ 'u Kukui rain gage indicated total rainfall amounts of 0.19 inch on March 19 and 0.05 inch on March 20, both of which would have minimal effect on streamflow. Because most of the discharges measured on Launiupoko Stream were very low, some measurements were made when Ukumehame Gulch indicated higher flows to help determine the statistical relation in the upper range of discharges. The MOVE.1 relation between measured discharges at the partial-record site and concurrent daily mean discharges at the index station has a correlation coefficient of 0.90 . Estimated low-flow duration discharges range from $0.34 \mathrm{ft}^{3} / \mathrm{s}\left(\mathrm{Q}_{95}\right.$ discharge $)$ to $0.47 \mathrm{ft}^{3} / \mathrm{s}$ $\left(\mathrm{Q}_{50}\right.$ discharge $)$. A majority of the discharges used for record augmentation at the partial-record site generally are between the $\mathrm{Q}_{95}$ and $\mathrm{Q}_{50}$ duration discharges; therefore, the flowduration estimates are considered to be representative of the low-flow conditions on Launiupoko Stream.

Table 12. Measured discharges at partial-record site 205117156365201 on Launiupoko Stream and partial-record site 16647000 on Ukumehame Gulch, west Maui, Hawai'i.

[ $\mathrm{ft}^{3} / \mathrm{s}$, cubic feet per second; -, not available; measured discharge not used in record augmentation is underlined]

\begin{tabular}{|c|c|c|}
\hline Date & $\begin{array}{l}\text { Measured discharges in } \mathrm{ft}^{3} / \mathrm{s} \\
\text { on Ukumehame Gulch }\end{array}$ & $\begin{array}{l}\text { Measured discharges in } \mathrm{ft}^{3} / \mathrm{s} \\
\text { on Launiupoko Stream }\end{array}$ \\
\hline 08/14/2008 & - & $\underline{0.48^{c}}$ \\
\hline 02/08/2012 & - & $\underline{0.31^{\mathrm{c}}}$ \\
\hline 03/20/2012 & $5.11^{\mathrm{b}}$ & 0.44 \\
\hline 05/01/2012 & - & $\underline{0.54}^{\mathrm{c}}$ \\
\hline $06 / 05 / 2012$ & 4.71 & 0.40 \\
\hline 06/26/2012 & 9.70 & 0.79 \\
\hline 06/29/2012 & 12.9 & $\underline{0.78}^{\mathrm{d}}$ \\
\hline $07 / 24 / 2012$ & 5.08 & 0.49 \\
\hline 08/23/2012 & 5.28 & 0.60 \\
\hline $10 / 12 / 2012$ & 4.00 & 0.48 \\
\hline $12 / 10 / 2012$ & 2.68 & 0.33 \\
\hline $02 / 12 / 2013$ & 10.2 & 0.62 \\
\hline $07 / 30 / 2013$ & 10.2 & 0.72 \\
\hline $11 / 20 / 2013$ & 3.82 & 0.35 \\
\hline
\end{tabular}

${ }^{a}$ Discharge measurements from June 2012-November 2013 were estimated from the measured stage and rating curve developed for this site. In cases for which both a discharge measurement and a discharge determination based on the rating curve were available, the discharge based on the rating curve was used in record augmentation.

${ }^{b}$ No direct measurement was made. Discharge assumed to be the same as the discharge on March 19, 2012 (see table 14) because rainfall records at $\mathrm{Pu}$ 'u Kukui rain gage indicated there was little rainfall, hence rainfall would have minimal affect on streamflow.

'Discharge not used in record augmentation because concurrent daily mean discharge at the index station was unavailable.

${ }^{\mathrm{d} D i s c h a r g e}$ not used in record augmentation because the hydrograph from the index station indicated highly variable flows during the time the measurement was made. 


\section{Low-Flow Characteristics of Streams in the Lahaina District, West Maui, Hawai'i}

\section{Olowalu Stream}

At partial-record site L14 on Olowalu Stream (fig. 1), 9 of 13 measurements made as part of this study were used to estimate flow-duration discharges for Olowalu Stream (table 13). The MOVE.1 relation between measured discharges at the partial-record site and concurrent daily mean discharges at the index station has a correlation coefficient of 0.96 . Estimated low-flow duration discharges range from $3.1 \mathrm{ft}^{3} / \mathrm{s}\left(\mathrm{Q}_{95}\right.$ discharge $)$ to $6.1 \mathrm{ft}^{3} / \mathrm{s}\left(\mathrm{Q}_{50}\right.$ discharge $)$. Most of the discharges used for record augmentation at the partial-record site are between the $\mathrm{Q}_{95}$ and $\mathrm{Q}_{50}$ duration discharges; therefore, the flow-duration estimates are considered to be representative of the low-flow conditions on Olowalu Stream.

Table 13. Measured discharges at partial-record site 205000156355801 on Olowalu Stream and concurrent daily mean discharges at streamflow-gaging station (index station) 16604500 on 'İao Stream, west Maui, Hawai'i.

[ $\mathrm{ft}^{3} / \mathrm{s}$, cubic feet per second; measured discharge not used in record augmentation is underlined.]

\begin{tabular}{|c|c|c|}
\hline Date & $\begin{array}{c}\text { Daily mean discharge in } \mathrm{ft}^{3} / \mathrm{s} \\
\text { on 'Tlao Stream }\end{array}$ & $\begin{array}{l}\text { Measured discharges in } \mathrm{ft}^{3} / \mathrm{s} \\
\text { on Olowalu Stream }\end{array}$ \\
\hline 02/09/2012 & 20 & 3.39 \\
\hline $03 / 23 / 2012$ & $37^{\mathrm{a}}$ & 6.54 \\
\hline 06/07/2012 & 28 & 4.35 \\
\hline $07 / 27 / 2012$ & 80 & ${\underline{5.43^{b}}}^{\mathrm{b}}$ \\
\hline 08/21/2012 & 77 & ${\underline{8.20^{\mathrm{b}}}}^{\mathrm{s}}$ \\
\hline 09/12/2012 & 53 & ${\underline{9.45^{\mathrm{b}}}}^{\mathrm{s}}$ \\
\hline $10 / 11 / 2012$ & 27 & 4.59 \\
\hline $11 / 07 / 2012$ & 21 & 3.37 \\
\hline $12 / 12 / 2012$ & 12 & 2.84 \\
\hline $01 / 15 / 2013$ & 31 & 6.08 \\
\hline $02 / 13 / 2013$ & 53 & 8.46 \\
\hline $04 / 15 / 2013$ & 23 & 4.29 \\
\hline 06/10/2013 & 52 & $\underline{5.29^{\mathrm{b}}}$ \\
\hline
\end{tabular}

aDaily mean discharge computed from partial record of flow, 18 continuous hours in a 24-hour period.

bDischarge not used in record augmentation because the hydrograph from the index station indicated highly variable flows during the time the measurement was made. 


\section{Ukumehame Gulch}

Fifteen of 34 measurements made at partial-record site L15 on Ukumehame Gulch (fig. 1) as part of this study were used to estimate flow-duration discharges (table 14). For measurements collected between August 2012 and July 2013 (except March 14, 2013), rating table discharges were used for the analysis. Discharge measured on March 14, 2013, was made without accompanying stage reading; therefore, the measured discharge was used instead of the rated discharge. The
MOVE.1 relation between measured discharges at the partialrecord site and concurrent daily mean discharges at the index station has a correlation coefficient of 0.94 . Estimated lowflow duration discharges range from $3.0 \mathrm{ft}^{3} / \mathrm{s}\left(\mathrm{Q}_{95}\right.$ discharge) to $5.0 \mathrm{ft}^{3} / \mathrm{s}\left(\mathrm{Q}_{50}\right.$ discharge $)$. A majority of the discharges used for record augmentation at the partial-record site are between the $\mathrm{Q}_{95}$ and $\mathrm{Q}_{50}$ duration discharges; therefore, the flow-duration estimates are considered to be representative of the low-flow conditions on Ukumehame Gulch.

Table 14. Measured discharges at partial-record site 16647000 on Ukumehame Gulch and concurrent daily mean discharges at streamflow-gaging station (index station) 16604500 on 'Tao Stream, west Maui, Hawai'i._Continued

$\left[\mathrm{ft}^{3} / \mathrm{s}\right.$, cubic feet per second; -, not available; measured discharge not used in record augmentation is underlined.]

\begin{tabular}{|c|c|c|c|}
\hline \multirow{2}{*}{ Date } & \multirow{2}{*}{$\begin{array}{c}\text { Daily mean discharge in } \mathrm{ft}^{3} / \mathrm{s} \\
\text { on 'Tlao Stream }\end{array}$} & \multicolumn{2}{|c|}{ Discharges in $\mathrm{ft}^{3} / \mathrm{s}$ on Ukumehame Gulch } \\
\hline & & Measured $^{a}$ & From rating curve ${ }^{\mathrm{b}}$ \\
\hline 07/06/1920 & - & $\underline{3.0^{c}}$ & - \\
\hline 07/20/1920 & - & $\underline{3.3}^{\mathrm{c}}$ & - \\
\hline 09/07/1920 & - & $\underline{7.4^{c}}$ & - \\
\hline $10 / 19 / 1920$ & - & $\underline{3.8^{\mathrm{c}}}$ & - \\
\hline $09 / 20 / 2006$ & 17 & 3.26 & - \\
\hline $02 / 06 / 2012$ & 15 & 2.71 & - \\
\hline 03/19/2012 & 34 & 5.11 & - \\
\hline $04 / 30 / 2012$ & 37 & $\underline{3.84^{\mathrm{e}}}$ & - \\
\hline $06 / 04 / 2012$ & 38 & 4.98 & $\underline{5.08}$ \\
\hline $06 / 05 / 2012$ & 55 & - & $\underline{4.71}$ \\
\hline $06 / 06 / 2012$ & $36^{\mathrm{d}}$ & - & $\underline{4.52}$ \\
\hline 06/07/2012 & $28^{d}$ & 4.55 & $\underline{4.52}$ \\
\hline 06/26/2012 & $55^{\mathrm{d}}$ & 9.90 & 9.7 \\
\hline $06 / 27 / 2012$ & $55^{\mathrm{d}}$ & 8.37 & $\underline{8.4}$ \\
\hline 06/29/2012 & $48^{\mathrm{d}}$ & 12.9 & $\underline{12.9}$ \\
\hline 07/23/2012 & $34^{\mathrm{d}}$ & 5.03 & $\underline{5.28}$ \\
\hline 07/24/2012 & $47^{\mathrm{d}}$ & - & $\underline{5.08}$ \\
\hline $07 / 25 / 2012$ & $32^{\mathrm{d}}$ & - & $\underline{4.71}$ \\
\hline 07/26/2012 & $29^{d}$ & 4.34 & $\underline{4.35}$ \\
\hline $08 / 21 / 2012$ & 77 & 5.87 & 5.68 \\
\hline 08/23/2012 & 170 & 5.47 & $\underline{5.28^{\mathrm{e}}}$ \\
\hline 09/10/2012 & 50 & - & 5.68 \\
\hline 09/12/2012 & 53 & - & $\underline{5.08^{\mathrm{e}}}$ \\
\hline $09 / 13 / 2012$ & 41 & 4.36 & 4.35 \\
\hline 09/14/2012 & 44 & - & $\underline{4.52^{\mathrm{e}}}$ \\
\hline
\end{tabular}


Table 14. Measured discharges at partial-record site 16647000 on Ukumehame Gulch and concurrent daily mean discharges at streamflow-gaging station (index station) 16604500 on 'Īao Stream, west Maui, Hawai'i.—Continued

[ft³ 3 s, cubic feet per second; -, not available; measured discharge not used in record augmentation is underlined.]

\begin{tabular}{|c|c|c|c|}
\hline \multirow{2}{*}{ Date } & \multirow{2}{*}{$\begin{array}{c}\text { Daily mean discharge in } \mathrm{ft}^{3} / \mathrm{s} \\
\text { on 'Tao Stream }\end{array}$} & \multicolumn{2}{|c|}{ Discharges in $\mathrm{ft}^{3} / \mathrm{s}$ on Ukumehame Gulch } \\
\hline & & Measured $^{\mathrm{a}}$ & From rating curve ${ }^{b}$ \\
\hline $10 / 09 / 2012$ & 23 & 4.32 & 4.17 \\
\hline $10 / 11 / 2012$ & 27 & - & ${\underline{4.35^{\mathrm{e}}}}^{2}$ \\
\hline $10 / 12 / 2012$ & 22 & - & 4.00 \\
\hline $11 / 05 / 2012$ & 16 & 2.87 & 2.68 \\
\hline 11/07/2012 & $19^{\mathrm{f}}$ & - & 3.30 \\
\hline $11 / 09 / 2012$ & 29 & - & $\underline{3.82^{\mathrm{e}}}$ \\
\hline $12 / 10 / 2012$ & 13 & 2.50 & 2.68 \\
\hline $12 / 11 / 2012$ & 12 & - & $\underline{2.71}^{\mathrm{g}}$ \\
\hline $12 / 12 / 2012$ & 12 & - & ${\underline{3.3^{\mathrm{g}}}}^{\mathrm{g}}$ \\
\hline $01 / 15 / 2013$ & 31 & - & 5.68 \\
\hline $02 / 12 / 2013$ & 92 & - & 10.2 \\
\hline 03/14/2013 & 21 & 3.85 & - \\
\hline 07/30/2013 & 95 & - & 10.2 \\
\hline $11 / 20 / 2013$ & $15^{\mathrm{h}}$ & 3.74 & $\underline{3.76}$ \\
\hline
\end{tabular}

${ }^{\mathrm{a}}$ Measured discharges June-December 2012 were used to develop rating curve for Ukumehame Gulch.

'Discharge measurements June 2012-November 2013 were estimated from the measured stage and rating curve developed for this site. In cases for which both a discharge measurement and a discharge determination based on the rating curve were available, the discharge based on the rating curve was used in record augmentation. Underlined discharges in June and July 2012 were not used in record augmentation because the index station experienced equipment malfunction.

${ }^{c}$ Discharge not used in record augmentation because concurrent daily mean discharge at the index station was unavailable.

${ }^{\mathrm{d} E s t i m a t e d ~ d a i l y ~ m e a n ~ d i s c h a r g e ~ d u e ~ t o ~ e q u i p m e n t ~ m a l f u n c t i o n ~ a n d ~ c a n n o t ~ b e ~ u s e d ~ i n ~ r e c o r d ~ a u g m e n t a t i o n . ~}$

${ }^{\mathrm{e}}$ Discharge not used in record augmentation because the hydrograph from the index station indicated highly variable flows during the time the measurement was made.

fDaily mean discharge computed from partial record of flow, 18 continuous hours in a 24-hour period.

${ }^{8}$ Discharge measured during recession of streamflow on the same day and was not used in record augmentation.

hProvisional data as of February 20, 2014; therefore, concurrent discharge measured at the partial-record site was not used in record augmentation.

\section{Ephemeral Streams}

The study-area streams that were observed to be dry at the partial-record sites during the reconnaissance survey from December 5 to 9, 2011, include Pāpua Gulch, Honokahua Stream and its tributary Mokupe'a Gulch, Kahana Stream, and Wahikuli Gulch and its tributary Hāhākea Gulch. These streams were monitored during the study period to determine how often the streams were dry. Continuous-record station 16620000 on Honokōhau Stream was the index station for these ephemeral streams because the discharge measurements at the neighboring study-area streams with measurable flow (Honolua and Honokōwai Streams) correlated well with the concurrent daily mean discharges on Honokōhau Stream. Based on observations made during the study period, these 6 ephemeral streams at the partial-record sites had zero flow at least 50 percent of the time (table 15). Pāpua Gulch, Honokahua Stream, and its tributary Mokupe'a Gulch were observed to be dry at the partial-record sites when concurrent daily mean discharges at the index station on Honokōhau
Stream were as high as the $\mathrm{Q}_{20}$ discharge. On May 14, 2008, Honokahua Stream had $0.32 \mathrm{ft}^{3} / \mathrm{s}$ of flow at an altitude of $1,020 \mathrm{ft}$, but eventually became dry at an altitude of $930 \mathrm{ft}$, when Honokōhau Stream was flowing at the $\mathrm{Q}_{80}$ discharge (Gingerich and Engott, 2012). Based on this observation, Honokahua Stream at the partial-record site at an altitude of $620 \mathrm{ft}$ was assumed to be dry as well. Kahana Stream was observed to be flowing at the partial-record site on June 25 and 28, 2012, when Honokōhau Stream was flowing at the $\mathrm{Q}_{13}$ discharge and higher, and the stream was observed to be dry when concurrent daily mean discharges at the index station on Honokōhau Stream were as high as the $\mathrm{Q}_{18}$ discharge. Wahikuli and Hāhākea Gulches were observed to be dry at the partial-record sites on the same days when concurrent daily mean discharges at the index station on Honokōhau Stream were as high as the $\mathrm{Q}_{18}$ discharge. However on June 25, 2012, flow was observed at the partial-record site on Hāhākea Gulch but not Wahikuli Gulch, and Honokōhau Stream was flowing at the $\mathrm{Q}_{13}$ discharge. This difference may be attributed to the location and size of the drainage areas. 
Table 15. Flow condition at partial-record sites on ephemeral streams and concurrent daily mean discharges at streamflow-gaging station (index station) 16620000 on Honokōhau Stream, west Maui, Hawai'i.

[ft $\mathrm{ft}^{3} / \mathrm{s}$, cubic feet per second]

\begin{tabular}{|c|c|c|c|}
\hline \multirow[b]{2}{*}{ Date } & \multirow{2}{*}{$\begin{array}{l}\text { Flow condition } \\
\text { at partial-record site }\end{array}$} & \multicolumn{2}{|c|}{ Honokōhau Stream } \\
\hline & & $\begin{array}{l}\text { Daily mean discharge, in } \\
\mathrm{ft}^{3} / \mathrm{s}\end{array}$ & $\begin{array}{c}\text { Flow percentile for } \\
1984-2013\end{array}$ \\
\hline \multicolumn{4}{|c|}{ Partial-record site 205921156370101 on Pāpua Gulch } \\
\hline 05/03/2012 & No flow & 41 & $\mathrm{Q}_{20}$ \\
\hline $12 / 06 / 2011$ & No flow & 14 & $\mathrm{Q}_{80}$ \\
\hline $03 / 22 / 2012$ & No flow & 33 & $\mathrm{Q}_{27}$ \\
\hline $02 / 07 / 2012$ & No flow & 39 & $\mathrm{Q}_{22}$ \\
\hline \multicolumn{4}{|c|}{ Partial-record site 205844156380501 on Honokahua Stream } \\
\hline $05 / 03 / 2012$ & No flow & 41 & $\mathrm{Q}_{20}$ \\
\hline $12 / 06 / 2011$ & No flow & 14 & $\mathrm{Q}_{80}$ \\
\hline $02 / 07 / 2012$ & No flow & 39 & $\mathrm{Q}_{22}$ \\
\hline $03 / 21 / 2012$ & No flow & 45 & $\mathrm{Q}_{18}$ \\
\hline \multicolumn{4}{|c|}{ Partial-record site 205938156382201 on Mokupe‘a Gulch } \\
\hline $02 / 08 / 2012$ & No flow & 12 & $\mathrm{Q}_{90}$ \\
\hline $05 / 03 / 2012$ & No flow & 41 & $\mathrm{Q}_{20}$ \\
\hline $06 / 0 \varepsilon^{\prime n n 1 n}$ & No flow & 31 & $\mathrm{Q}_{29}$ \\
\hline $03 / 21 / 2012$ & No flow & 45 & $\mathrm{Q}_{18}$ \\
\hline \multicolumn{4}{|c|}{ Partial-record site 205740156385601 on Kahana Stream } \\
\hline $02 / 08 / 2012$ & No flow & 12 & $\mathrm{Q}_{90}$ \\
\hline $12 / 06 / 2011$ & No flow & 14 & $\mathrm{Q}_{80}$ \\
\hline $05 / 02 / 2012$ & No flow & 20 & $\mathrm{Q}_{52}$ \\
\hline $06 / 08 / 2012$ & No flow & 31 & $\mathrm{Q}_{29}$ \\
\hline $03 / 21 / 2012$ & No flow & 45 & $\mathrm{Q}_{18}$ \\
\hline $06 / 25 / 2012$ & Flow observed & 58 & $\mathrm{Q}_{13}$ \\
\hline $06 / 28 / 2012$ & Flow observed & 185 & $>\mathrm{Q}_{5}$ \\
\hline \multicolumn{4}{|c|}{ Partial-record site 205511156393401 on Wahikuli Gulch } \\
\hline $02 / 08 / 2012$ & No flow & 12 & $\mathrm{Q}_{90}$ \\
\hline $12 / 05 / 2011$ & No flow & 19 & $\mathrm{Q}_{55}$ \\
\hline $05 / 01 / 2012$ & No flow & 21 & $\mathrm{Q}_{50}$ \\
\hline $06 / 08 / 2012$ & No flow & 31 & $\mathrm{Q}_{29}$ \\
\hline $03 / 21 / 2012$ & No flow & 45 & $\mathrm{Q}_{18}$ \\
\hline $06 / 25 / 2012$ & No flow & 58 & $\mathrm{Q}_{13}$ \\
\hline \multicolumn{4}{|c|}{ Partial-record site 205455156394201 on Hāhākea Gulch } \\
\hline $02 / 08 / 2012$ & No flow & 12 & $\mathrm{Q}_{90}$ \\
\hline $12 / 05 / 2011$ & No flow & 19 & $\mathrm{Q}_{55}$ \\
\hline 05/01/2012 & No flow & 21 & $\mathrm{Q}_{50}$ \\
\hline $06 / 08 / 2012$ & No flow & 31 & $\mathrm{Q}_{29}$ \\
\hline $03 / 21 / 2012$ & No flow & 45 & $\mathrm{Q}_{18}$ \\
\hline $06 / 25 / 2012$ & Flow observed & 58 & $\mathrm{Q}_{13}$ \\
\hline $06 / 28 / 2012$ & No flow & 185 & $>Q_{5}$ \\
\hline
\end{tabular}




\section{Streamflow Gains and Losses}

Spatial distribution of streamflow at ungaged sites downstream of partial-record sites in the study-area streams were characterized by seepage-run measurements. Seepage runs are same-day discharge measurements made at selected sites along the stream, during stable-flow conditions, to determine the magnitude of streamflow gains and losses and to document stream reaches that are either flowing or dry. Different reaches of the same stream can either gain water (groundwater discharge into stream) or lose water (stream discharge into groundwater body) depending on the position of the water table relative to the streambed. When coupled with low-flow duration discharge estimates at the partialrecord sites, seepage-run measurements could provide natural water-availability information for stream reaches downstream from surface-water diversions and help determine whether the streams flow continuously from the mountains to the ocean (mauka to makai flow).

Seepage runs made for this study were conducted during the season when existing seepage-run data were limited or unavailable. For example, if a seepage run on a particular stream was previously conducted during the wet season, then for this study the seepage run on that stream was conducted in the dry season. The goal was to collect information on the distribution of flow along the streams that was representative of various low-flow conditions. Seepage gains and losses along a reach were computed as the difference between the upstream and downstream discharges, excluding any tributary inflows and diversions of water within the reach. To determine whether a stream supports mauka to makai flow under naturalflow conditions, seepage rates (expressed as the streamflow gain or loss in $\mathrm{ft}^{3} / \mathrm{s}$ per mile of stream reach $\left.\left[\left(\mathrm{ft}^{3} / \mathrm{s}\right) / \mathrm{mi}\right]\right)$ computed using discharges on measured reaches were extrapolated to nearby reaches on the same stream where measurements were not available.

For this study, seepage runs were conducted on Honolua, Honokōwai, Kahoma, Kanahā, and Olowalu Streams, and Ukumehame Gulch. Gingerich and Engott (2012) conducted an extensive 4-day seepage run on Kaua 'ula Stream to estimate potential streamflow loss contributing to groundwater recharge. Results of the seepage runs conducted for this study, as well as results of previous seepage runs, are summarized in table 16 and figures $10-15$. No seepage run was conducted on Launiupoko Stream as part of this study because the stream below the diversion intake was dry and a temporary release of flow from the diversion intake could not be coordinated during the study period. Seepage runs were not conducted on Honokahua Stream, Kahana Stream, and Wahikuli Gulch because of the ephemeral nature of flow in the streams. Seepage-run results show that a majority of the streams in the study area are losing streams downstream from diversions. Measured seepage-loss rates ranged between 0.045 and $1.6\left(\mathrm{ft}^{3} / \mathrm{s}\right) / \mathrm{mi}$. Seepage gains mostly occurred upstream from diversions and the measured seepage-gain rates generally ranged between 0.75 and $5.1\left(\mathrm{ft}^{3} / \mathrm{s}\right) / \mathrm{mi}$; one short reach had a measured seepage-gain rate of $35\left(\mathrm{ft}^{3} / \mathrm{s}\right) / \mathrm{mi}$. 


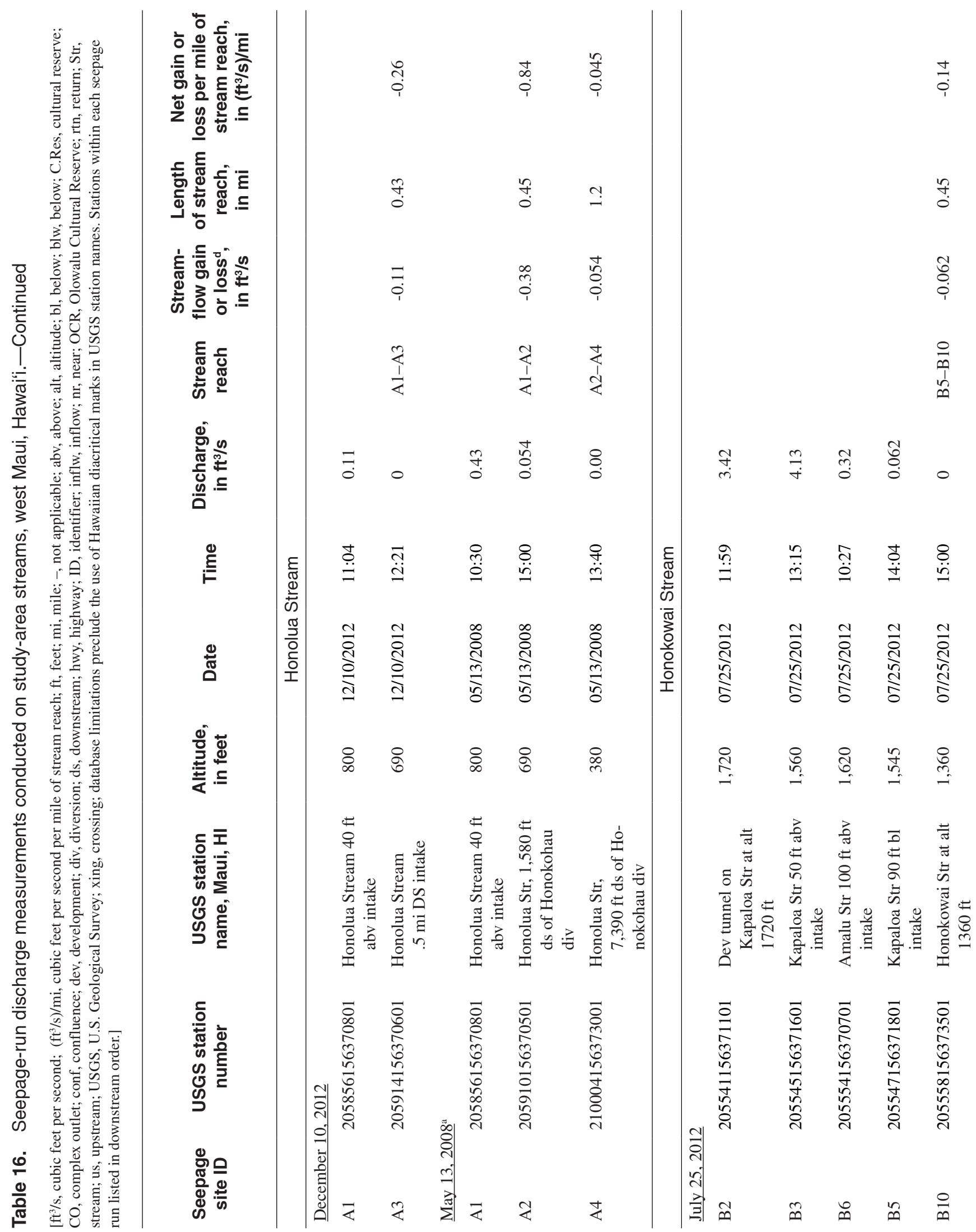




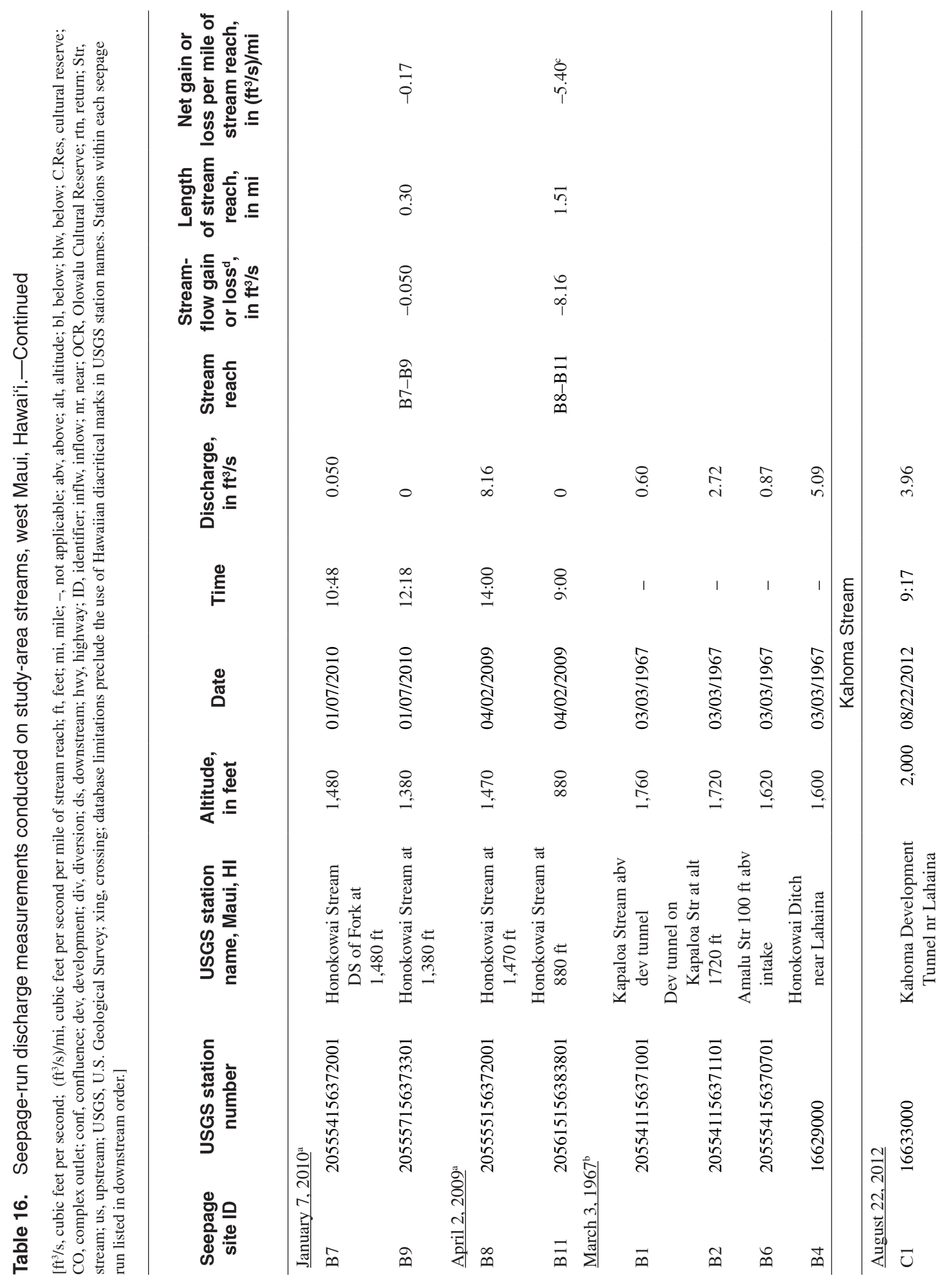




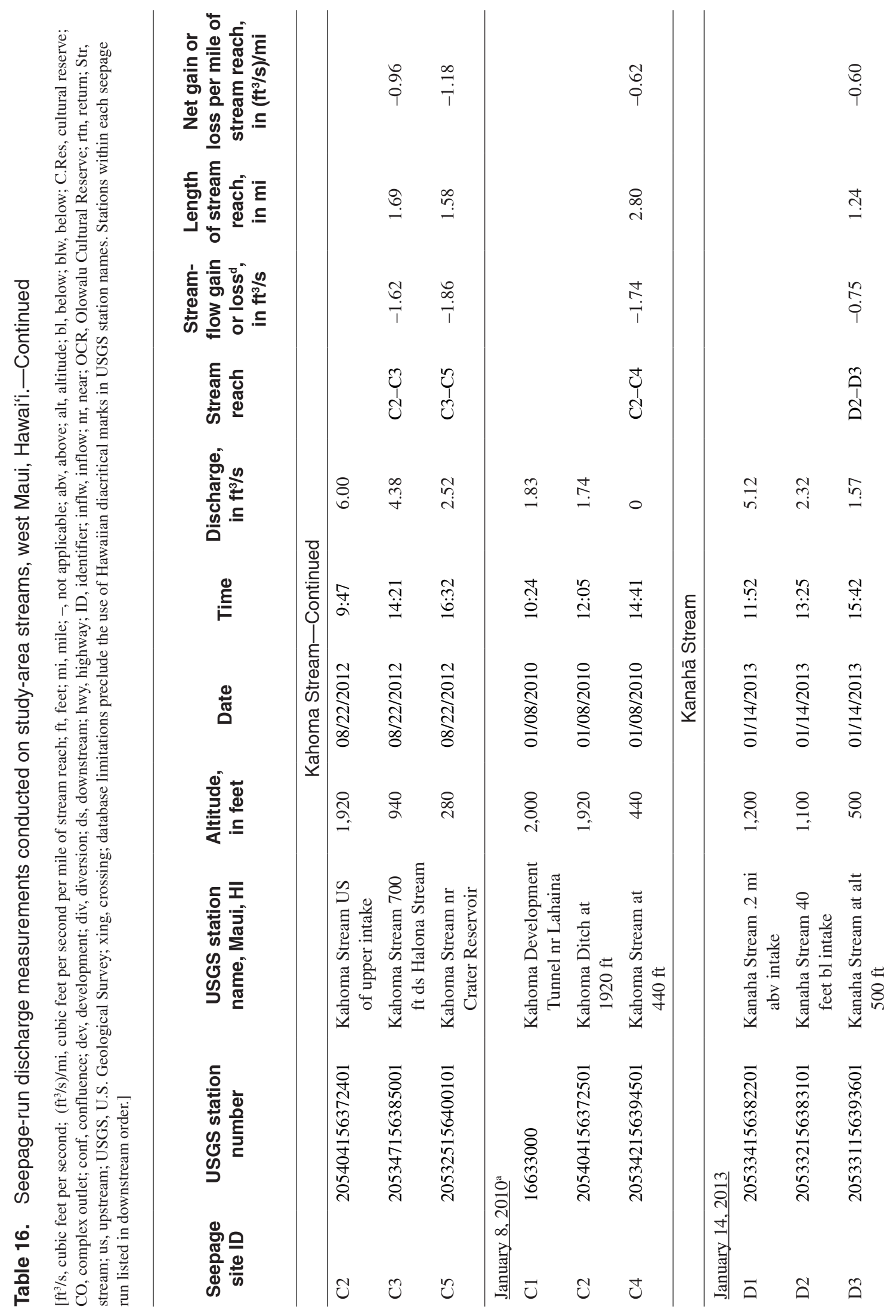




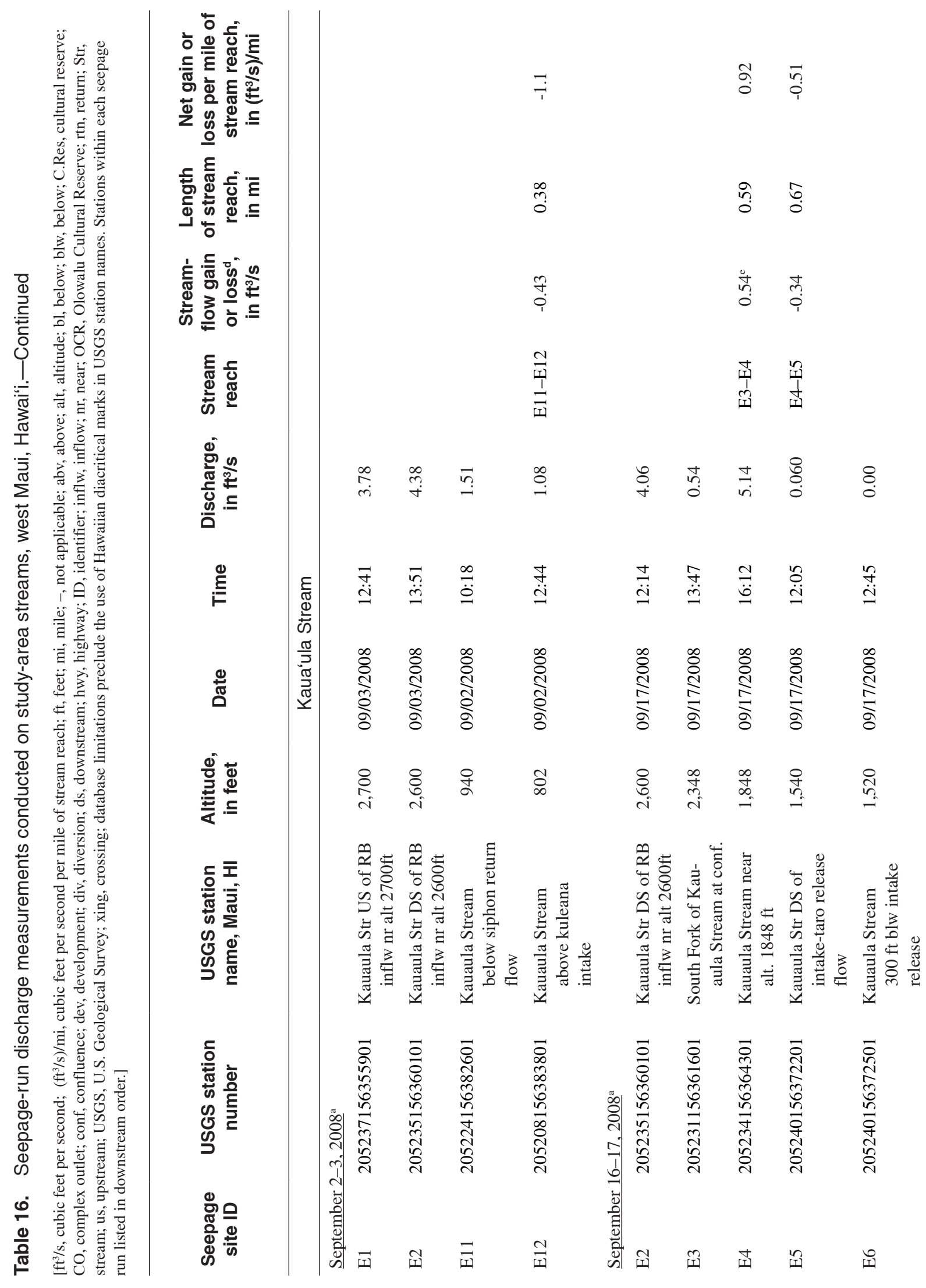




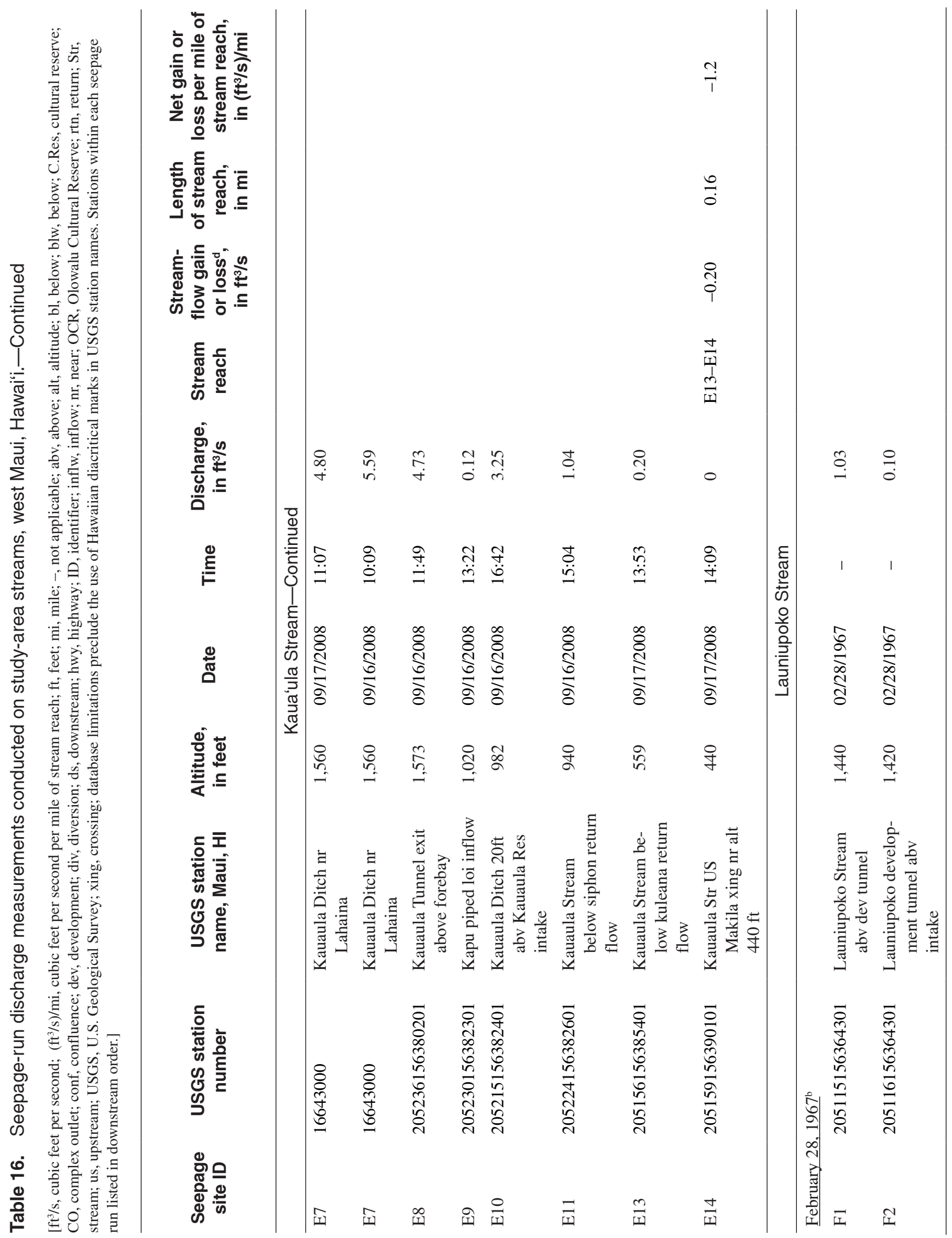




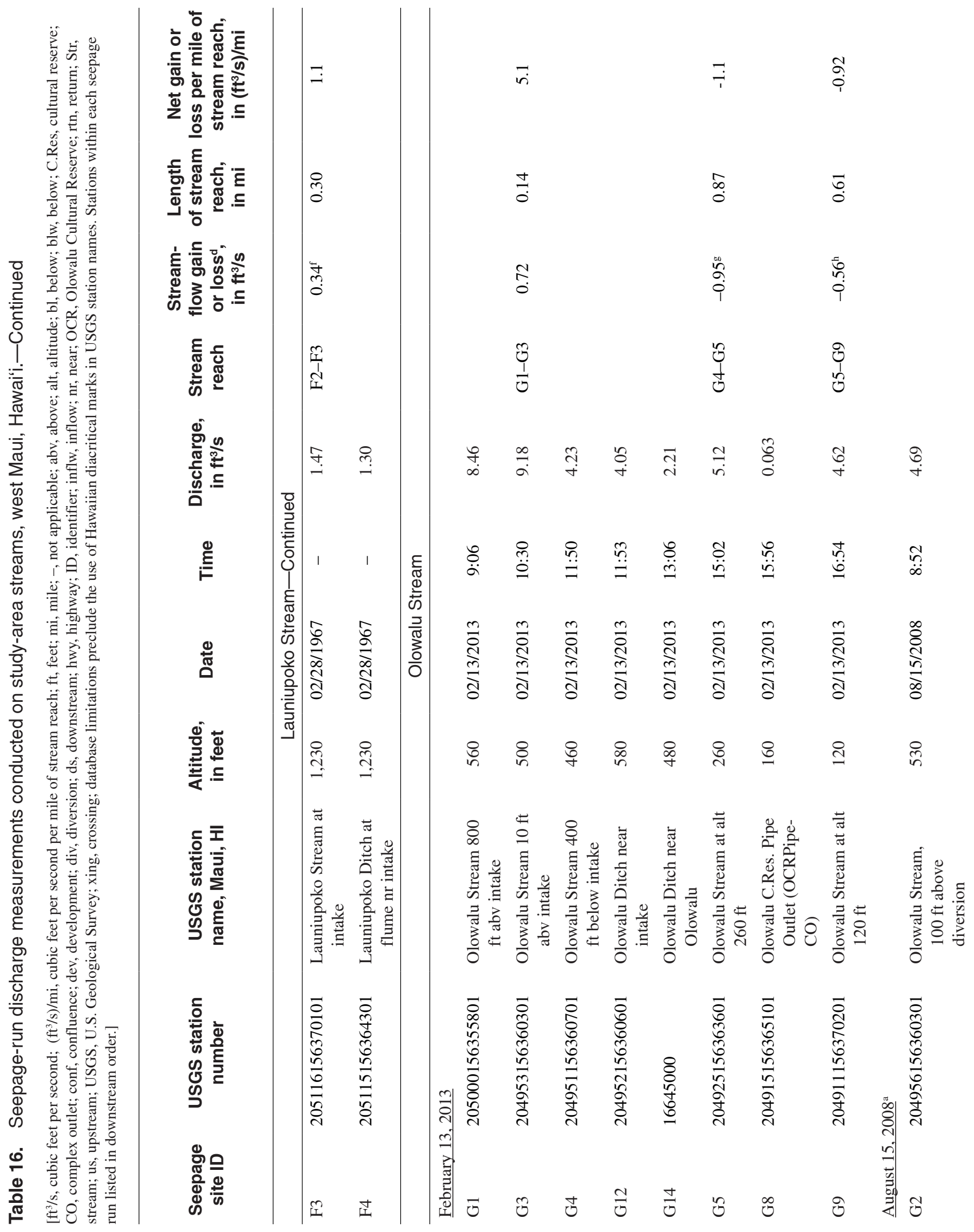




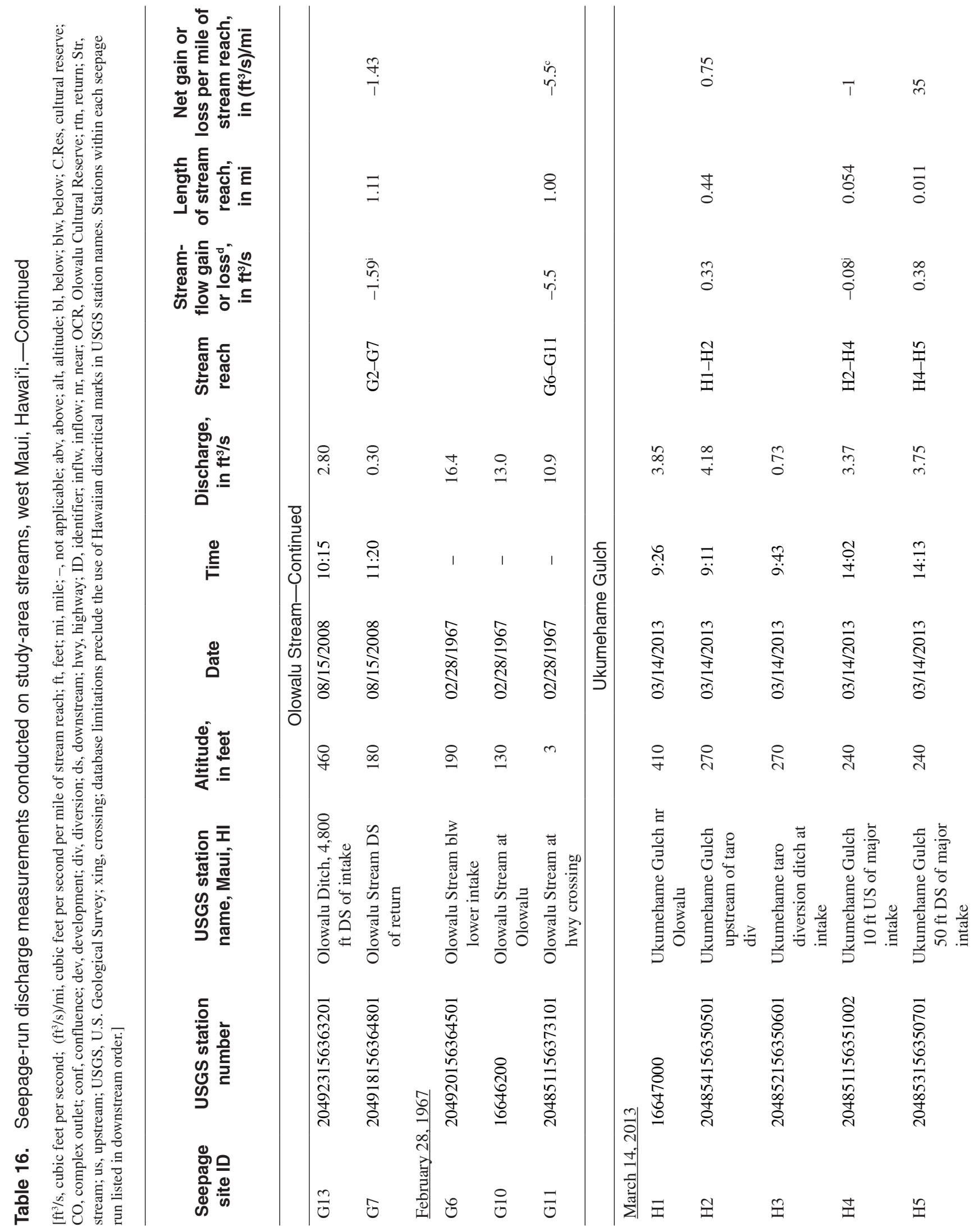




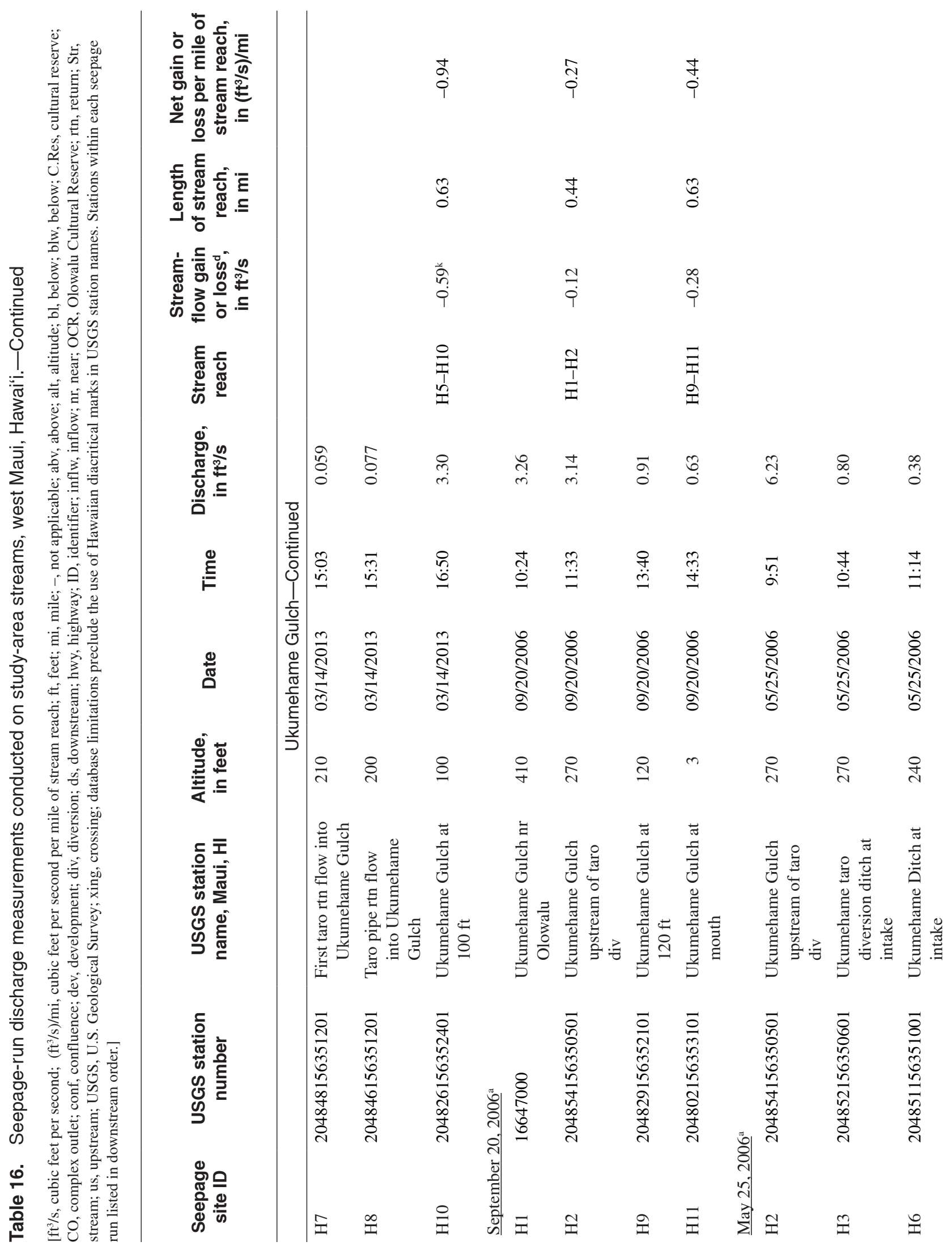




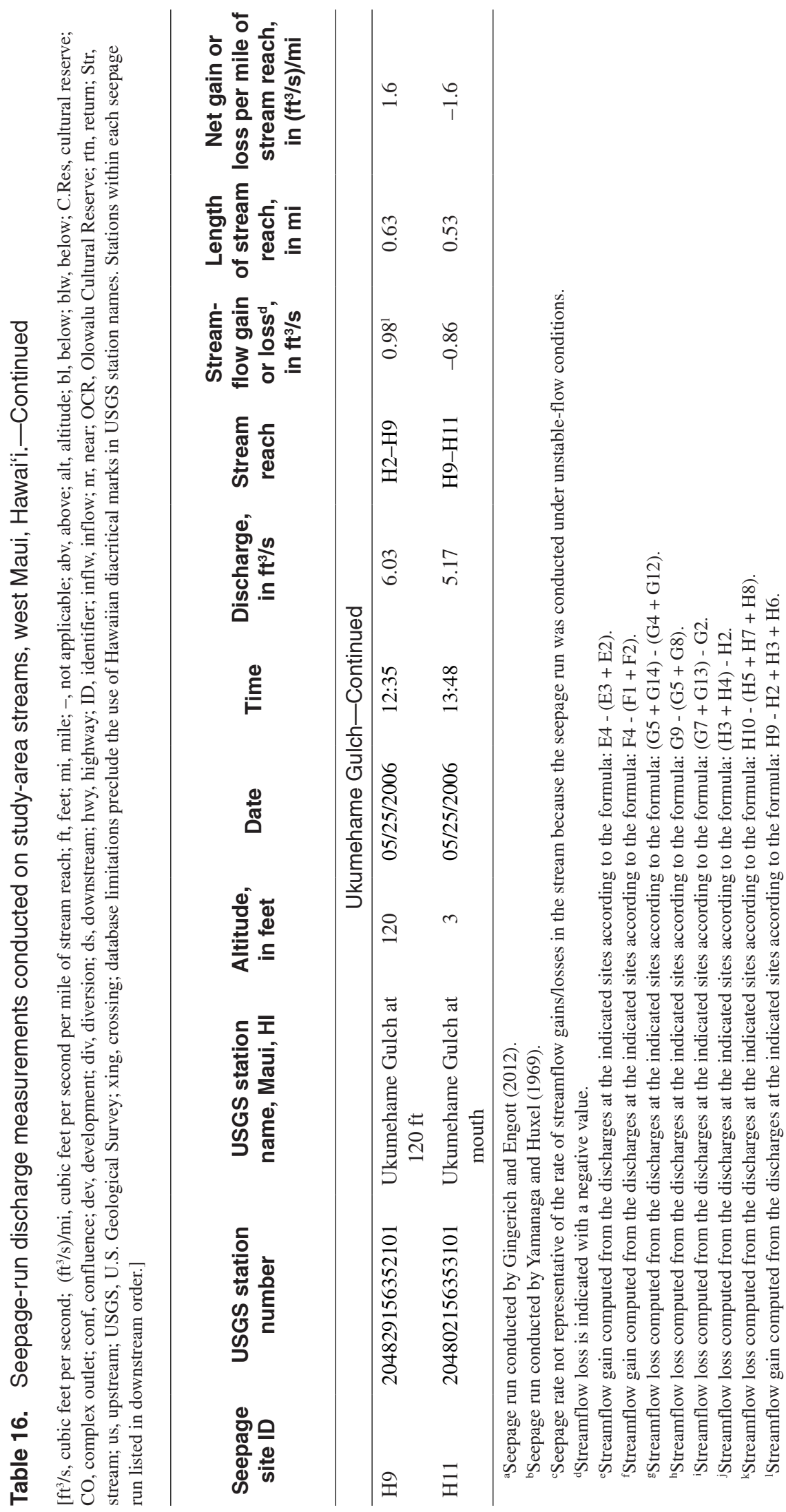




\section{Honolua Stream}

Available seepage-run measurements for Honolua Stream indicate spatially discontinuous flow downstream from the Honokōhau Ditch intake and an absence of mauka to makai flow at $\mathrm{Q}_{80}$ flow conditions. On December 10, 2012, discharges were measured at two sites (A1 and A3) located between stream-channel altitudes of 690 and $800 \mathrm{ft}$ (table 16, fig. 8). The uppermost site (A1), partial-record site L01 in this study (table 3, fig. 1), was $40 \mathrm{ft}$ upstream from the diversion intake and the lowermost site (A3) was about $0.5 \mathrm{mi}$ downstream from the diversion intake. No diversion of surface water from Honolua Stream into Honokōhau Ditch occurred during the seepage run. Flow in Honolua Stream at the measurement sites ranged from 0 to $0.11 \mathrm{ft}^{3} / \mathrm{s}$, and Honolua Stream discharge at site $\mathrm{A} 1$ was at about the $\mathrm{Q}_{85}$ discharge (table 6, site L01). In the 0.43-mi reach downstream from the intake, Honolua Stream was observed to be losing and gaining small amounts of flow. The stream was dry in two reaches totaling $500 \mathrm{ft}$ but regained small amounts of flow before becoming dry again at an altitude of $690 \mathrm{ft}$ (site A3). Results of the December 2012 seepage run are consistent with those from the seepage run conducted by Gingerich and Engott (2012) on May 13, 2008. During that seepage run, Honolua Stream discharge at site $\mathrm{A} 1$ was at about the $\mathrm{Q}_{80}$ discharge. Honolua Stream, not diverted at the time of the seepage run, lost $0.43 \mathrm{ft}^{3} / \mathrm{s}$ of flow in the 1.6-mi reach downstream from the diversion intake. The stream was dry in four reaches totaling 2,060 ft and the stream remained dry below an altitude of $380 \mathrm{ft}$.

\section{Honokōwai Stream}

Seepage-run measurements available for Honokōwai Stream indicate a generally losing stream downstream from the confluence of Kapāloa and Amalu Streams and the absence of mauka to makai flow at least 50 percent of the time. Upstream from the Kapāloa Stream ditch intake, a development tunnel contributes a substantial part of the flow in the stream during low-flow conditions.

The Honokōwai Stream seepage run for this study was conducted on July 25, 2012, and consisted of five measurement sites located between stream-channel altitudes of 1,360 and 1,720 ft (sites B10, and B2, table 16, fig. 9). The diversion intakes on Amalu and Kapāloa Streams were diverting all the water from the streams during the seepage run. Discharge measured at site B2 represented inflow from a development tunnel to Kapāloa Stream, and this discharge is considered water that would otherwise have naturally discharged to Kapāloa Stream. Two of the sites (B3 and B6) located upstream from the diversion intakes on Kapāloa and Amalu Streams were also partial-record sites L06 and L07 in this study (table 3, fig. 1). A measurement was made below the ditch intake on Kapāloa Stream (site B5) to quantify leakage from the diversion. The lowermost site (B10) was located on the main channel of Honokōwai Stream. Discharge measurements made in the Honokōwai Stream valley ranged from 0 to
$4.13 \mathrm{ft}^{3} / \mathrm{s}$. A flow of $4.13 \mathrm{ft}^{3} / \mathrm{s}$ was measured upstream from the Kapāloa Stream intake (site B3); the magnitude of flow from the development tunnel (site B2) was about 83 percent of the flow at that site. The total natural flow from the two tributaries (sites B3 and B6 combined) was $4.45 \mathrm{ft}^{3} / \mathrm{s}$, which was about the $\mathrm{Q}_{70}$ discharge (table 6, site L06 + L07). Downstream from the Kapāloa Stream ditch intake at site B5, $0.062 \mathrm{ft}^{3} / \mathrm{s}$ of flow was leaking from the diversion (fig. 10), and Amalu Stream downstream from the transmission tunnel intake was dry. Based on measurements at sites B3 to B5, the amount of flow diverted from Kapāloa and Amalu Streams during the seepage run was $4.39 \mathrm{ft}^{3} / \mathrm{s}$, which is consistent with the diversion estimate provided by KLM (see section "Surface-water Diversions"). The stream ran dry about $0.3 \mathrm{mi}$ downstream from the confluence of Kapāloa and Amalu Streams (site B10).

In the 24-hour period prior to the seepage run, 0.23 inch of rain was recorded at the $\mathrm{Pu}$ ' $\mathrm{u}$ Kukui rain gage. Records at streamflow-gaging station 16620000 on Honokōhau Stream indicate a small rise in flow during the early morning hours. Stage readings collected during the seepage run show the rainfall had minimal effect on the seepage-run results. When the discharges upstream from the diversions were being measured, stage readings at the reference point and at each discharge-measurement site did not change, indicating stableflow conditions despite the streamflow rise that occurred in Honokōhau Stream. However, discharges at sites B5 and B10 were measured when the stage at site B3 receded by $0.06 \mathrm{ft}$, indicating unstable-flow conditions in the stream. The receding flow had minimal effect on these last two measurements because all the flow in the stream channel measured at these locations represented leakage from the diversion on Kapāloa Stream, and the small amount of leakage probably did not vary much during the seepage run.

Results of the July 2012 seepage run are consistent with those from a previous seepage run conducted on January 7 , 2010, during which Honokōwai Stream lost $0.05 \mathrm{ft}^{3} / \mathrm{s}$ of flow in the 0.3-mi reach from the confluence of Kapāloa and Amalu Streams to an altitude of 1,380 ft (site B9). The location in the stream where it became dry in January 2010 was nearly the same as that from the July 2012 seepage run (table 16).

The seepage run on April 2, 2009, was conducted when the daily mean discharge at the index station on Honokōhau Stream was at the $\mathrm{Q}_{11}$ discharge for base period 1984-2013. Because of unstable-flow conditions that occurred during the seepage run, the results of that seepage run are not representative of the magnitude of seepage losses in the stream. However, the rainfall and streamflow conditions prior to the seepage run allow for certain assumptions to be made in order to determine the likelihood of mauka to makai flow under lowflow conditions. Four days prior to the seepage run, a cumulative rainfall of 8.82 inches was recorded at the $\mathrm{Pu}$ ' $\mathrm{u}$ Kukui rain gage and the daily mean discharges at the index station exceeded the $\mathrm{Q}_{55}$ discharge (table 4 ). On the day of the seepage run, 0.94 inch of rain was recorded during the early morning hours before any seepage-run measurements were made on Honokōwai Stream. Considering the antecedent rainfall 


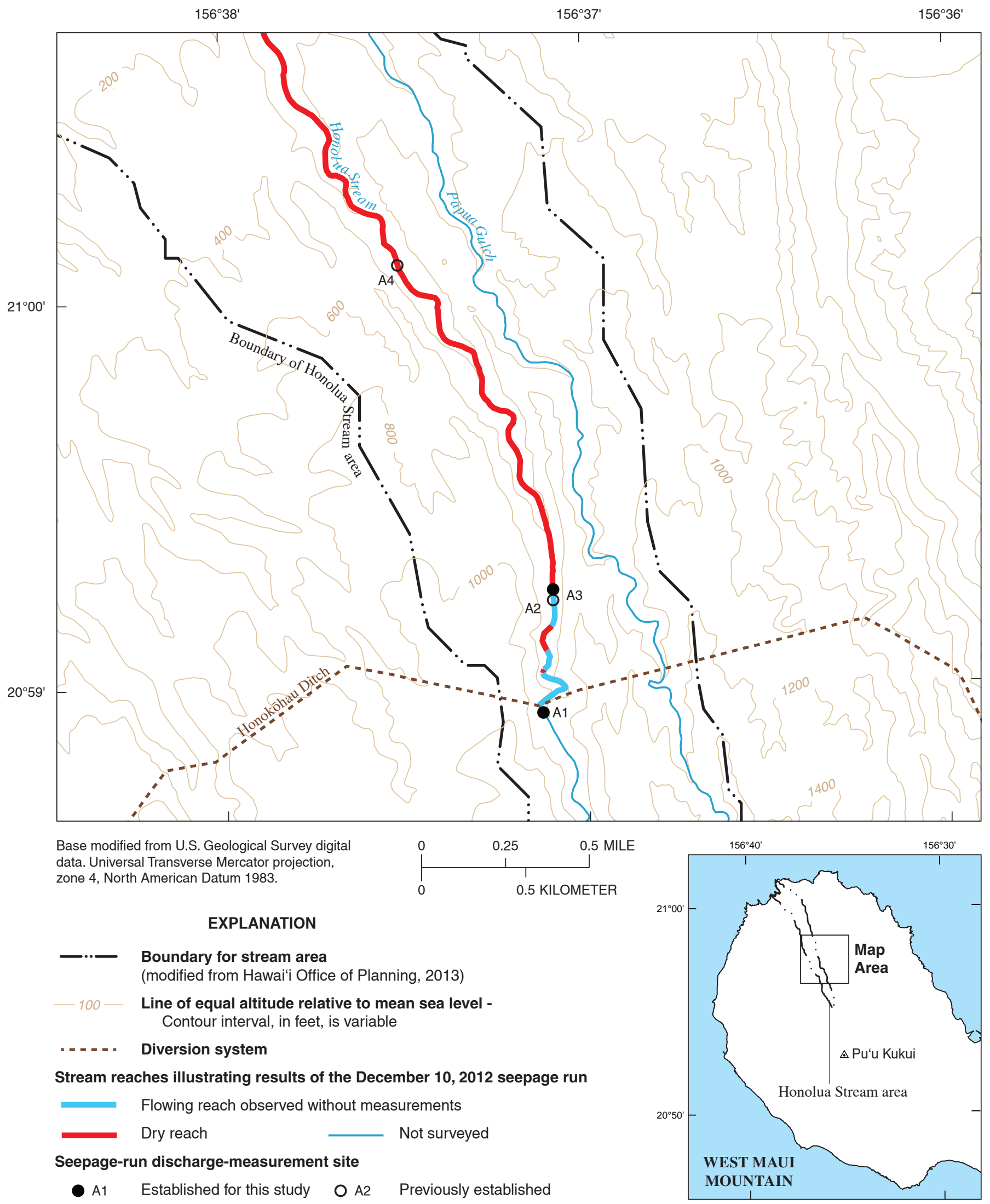

Figure 8. Map of seepage-run measurement sites for Honolua Stream, west Maui, Hawai'i. 
conditions, flow on Honokōwai Stream is assumed to be higher than $\mathrm{Q}_{55}$ flow conditions during the time the stream was observed to be dry at an altitude $880 \mathrm{ft}$ (site B11). Because the stream is estimated to lose additional flow from site B11 to the stream mouth, Honokōwai Stream will most likely become dry before reaching the ocean at median $\left(\mathrm{Q}_{50}\right)$ flow conditions.

On March 3, 1967, all measurements were made upstream from the confluence of Kapāloa and Amalu Streams. The development tunnel on Kapāloa Stream (site B2) contributed about 82 percent of the total flow in the stream at the tunnel exit. A flow of $0.90 \mathrm{ft}^{3} / \mathrm{s}$ was gained from a second development tunnel within the transmission tunnel and (or) the stream reach between sites B2 and the Kapāloa Stream diversion.

\section{Kahoma Stream}

Available seepage-run measurements for Kahoma Stream show a generally losing stream from the upper Kahoma Ditch intake to the confluence with Kanahā Stream. Under natural-flow conditions, the stream is estimated to flow to the confluence with Kanahā Stream between 85 and 90 percent of the time, assuming a total streamflow loss of $3.48 \mathrm{ft}^{3} / \mathrm{s}$ that occurred during the August 2012 seepage run in the stream reach between the upper ditch intake and the confluence with Kanahā Stream. Upstream from the upper Kahoma Ditch intake, a development tunnel contributes a substantial part of the flow in the stream during low-flow conditions.

On August 22, 2012, discharges were measured at four sites located between stream-channel altitudes of 280 and 2,000 ft (sites C5 and C1, table 16, fig. 11). Discharge at the uppermost site $(\mathrm{C} 1)$ represented flow from a development tunnel to Kahoma Stream; this discharge is considered water that would otherwise have naturally discharged to Kahoma Stream. A measurement was made upstream of the upper Kahoma Ditch intake (site C2), which was also partial-record site L10 in this study (table 3, fig. 1). Two of the sites (C3 and C5) were located downstream of the upper diversion intake on the main channel of Kahoma Stream. All of the water diverted at the upper Kahoma Ditch intake was returned to Kahoma Stream through a sluice gate downstream of the diversion intake. Flow in Kahoma Stream at the measurement sites ranged from 2.52 to $6.00 \mathrm{ft}^{3} / \mathrm{s}$. About 66 percent of the $6.00 \mathrm{ft}^{3} / \mathrm{s}$ measured at site $\mathrm{C} 2$, which represents total flow upstream from the upper ditch, was from the development tunnel (site C1) assuming minimal seepage gains or losses in the 300-ft stream reach between the two sites. The 1.69-mi reach of Kahoma Stream between the upper intake and the confluence of Kahoma and (dry) Hālona Streams lost $1.62 \mathrm{ft}^{3} / \mathrm{s}$ of flow to the subsurface, representing a 27-percent seepage loss from the discharge measured at the upper ditch (site $\mathrm{C} 2$ ). In the 1.58-mi reach downstream from the confluence at site C3, Kahoma Stream lost an additional $1.86 \mathrm{ft}^{3} / \mathrm{s}$ of flow, representing a 42-percent seepage loss from the discharge measured at site C3. Kahoma Stream discharge at site C2 was higher than the median discharge during the seepage run (table 6, site L10). Because of the receding stage that occurred during the seepage run, the actual seepage losses may be less than the estimated seepage losses.

Results of the August 2012 seepage run are consistent with those from a previous seepage run conducted on January 8, 2010, during which flow at site $\mathrm{C} 2$ was below $\mathrm{Q}_{95}$ flow conditions (table 6, site L10). Under natural-flow conditions, Kahoma Stream lost $1.74 \mathrm{ft}^{3} / \mathrm{s}$ of flow in the 2.8 -mi reach between the upper intake to an altitude of $440 \mathrm{ft}$ (sites C2-C4) where the stream became dry.

\section{Kanahā Stream}

Seepage-run measurements for Kanahā Stream show a generally losing stream downstream from the upper intake under low-flow conditions. Under natural-flow conditions, Kanahā Stream is estimated to flow to the confluence with Kahoma Stream at least 95 percent of the time assuming (1) a total streamflow loss of $0.75 \mathrm{ft}^{3} / \mathrm{s}$ that occurred during the January 2013 seepage run in the stream reach between the upper ditch intake and site D3, and (2) a seepage-loss rate of $0.60\left(\mathrm{ft}^{3} / \mathrm{s}\right) / \mathrm{mi}$ between site D3 and the confluence with Kahoma Stream. Downstream from the confluence of the two streams, the channel is mostly concrete-lined. Assuming minimal seepage flows within this reach, the stream is estimated to flow to the ocean at least 95 percent of the time.

On January 14, 2013, discharges were measured at three sites located between stream-channel altitudes of 500 and 1,200 ft (sites D3 and D1, table 16, fig. 11). The uppermost site (D1), also partial-record site L11 in the study (table 3, fig. 1), was located $0.2 \mathrm{mi}$ upstream from the upper intake and the lowermost site (D3) was about $0.5 \mathrm{mi}$ upstream from the confluence of Kanahā and Kahoma Streams. The seepage run was conducted during diverted conditions with partial release of flow from the upper intake to the stream. Flow in Kanahā Stream at the measurement sites ranged from 1.57 to $5.12 \mathrm{ft}^{3} / \mathrm{s}$. Kanahā Stream discharge at site D1 was higher than the median discharge (table 6, site L11), which indicated possible occurrence of runoff in the stream. However, stage readings collected during the seepage run did not indicate variable-flow conditions. Measurements at sites D1 and D2 were made to estimate the amount of water diverted at the upper intake. Three days prior to the seepage run, flow was partially released from a sluice gate immediately downstream of the upper intake. Assuming minimal seepage flows in the reach between sites D1 and D2, the amount of flow diverted at the upper intake on the day of the seepage run was about $2.8 \mathrm{ft}^{3} / \mathrm{s}$, which was 27 percent more than the 2009-10 average provided by MDWS. In the 1.24-mi reach downstream from the upper intake, Kanahā Stream lost $0.75 \mathrm{ft}^{3} / \mathrm{s}$ of flow to the subsurface, representing a 32-percent seepage loss relative to the discharge at site D2. This seepage run was conducted under higher flow conditions to allow the partial release of diverted water to the stream while maintaining adequate flow in the ditch for downstream use. Because about half of the flow remained in the stream downstream from the diversion dam, streamflows in the lower reaches are representative of low-flow conditions. 


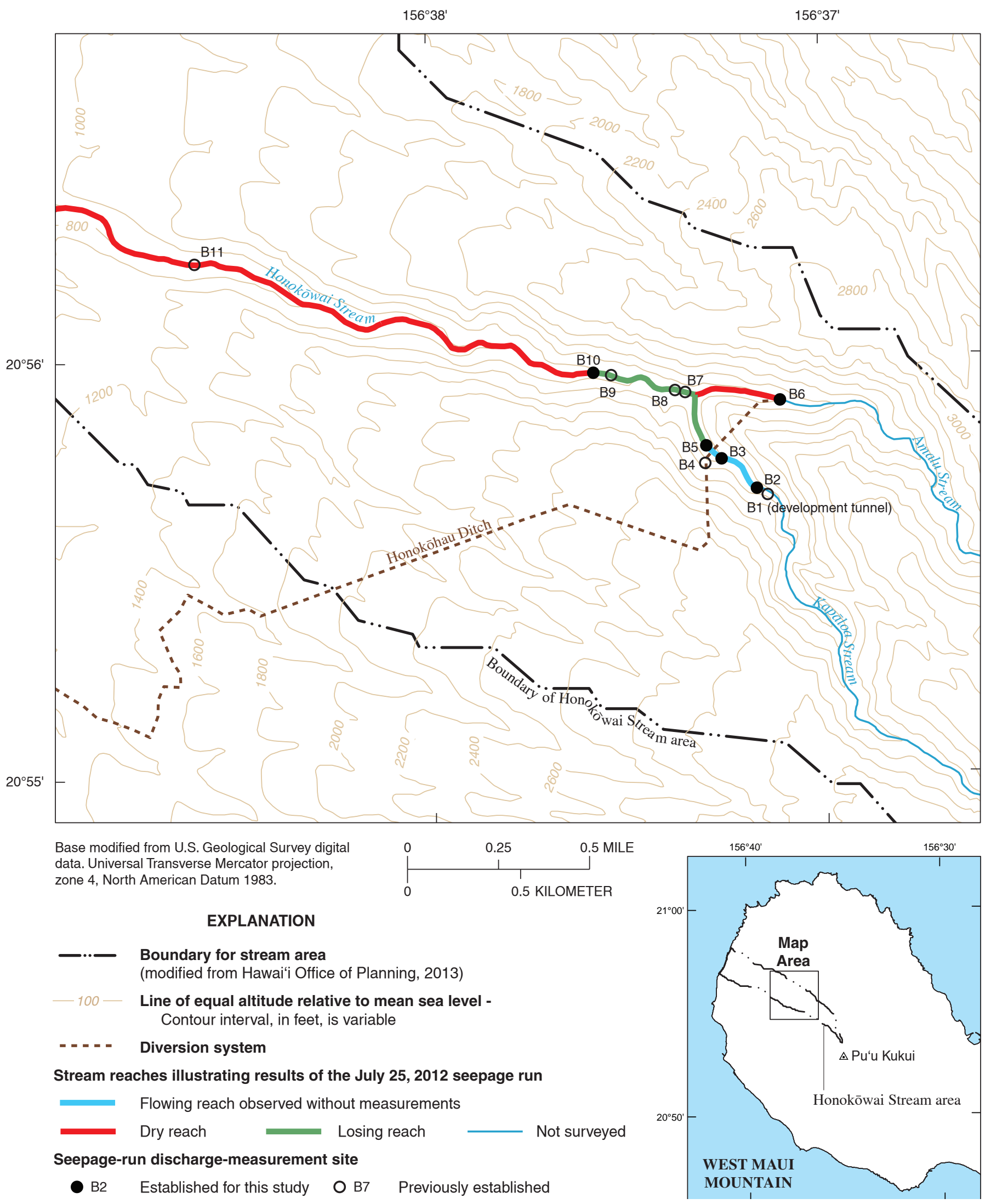

Figure 9. Map of seepage-run measurement sites for Honokōwai Stream, west Maui, Hawai'i. 


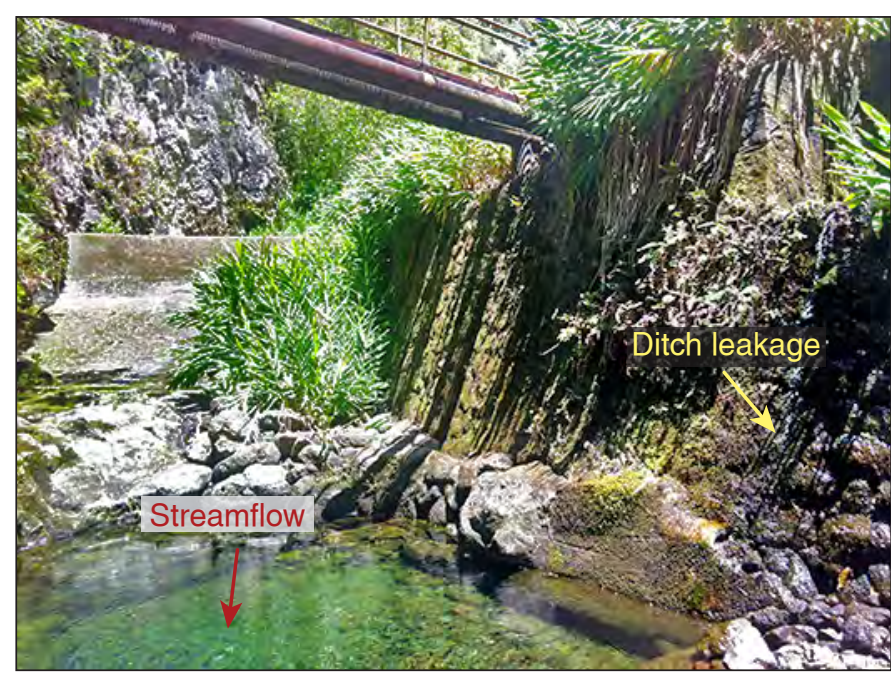

Figure 10. Photograph showing leakage from Honokōhau Ditch downstream from the diversion dam on Kapāloa Stream, Maui, Hawai'i, during the seepage run on July 25, 2012.

\section{Kaua'ula Stream}

Available seepage-run measurements show two of the measured reaches, sites E11-E12 and sites E13-E14 (table 16), have similar seepage-loss rates of 1.1 and $1.2\left(\mathrm{ft}^{3} / \mathrm{s}\right) / \mathrm{mi}$, respectively. Assuming a seepage-loss rate of $1.2\left(\mathrm{ft}^{3} / \mathrm{s}\right) / \mathrm{mi}$ in the unmeasured stream reaches of Kaua'ula Stream downstream from the upper intake, the stream is estimated to flow to the ocean at least 95 percent of the time under naturalflow conditions.

Gingerich and Engott (2012) conducted a seepage run on Kaua 'ula Stream that consisted of two partially overlapping surveys in 2008. The first survey was on September 2-3, 2008, and the second survey was on September 16-17, 2008. During the September 2-3 survey, discharge measurements were made at four sites between stream-channel altitudes of 802 and 2,700 ft above mean sea level (sites E12 and E1, table 16, fig. 12). The two uppermost sites (E1 and E2) were upstream and downstream from a development tunnel. One of the sites (E11) was located downstream from the Kaua 'ula Ditch siphon return flow at an altitude of $940 \mathrm{ft}$. Site E12 was located upstream from the lowermost diversion in Kaua 'ula Stream that provided water for small-scale agriculture within the valley. During the September 16-17 survey, discharge measurements were made at 12 sites between stream-channel altitudes of 440 and 2,600 ft above mean sea level (sites E14 and E2, table 16). Eight of the 12 sites were located in Kaua 'ula Stream and the remaining four sites (E7-E10) were located in ditches and other conduits that transported diverted water. Discharge measurements at sites E2 and E11 were made during both surveys in order to compare flow conditions for the first and second surveys of the seepage run.

Results of the September 2008 seepage run indicate that Kaua 'ula Stream is generally a losing stream downstream from the Kaua'ula Ditch intake. During the seepage run, flow in Kaua 'ula Stream ranged from no flow to $5.59 \mathrm{ft}^{3} / \mathrm{s}$ (table 16). Because all the water in the stream was diverted into Kaua'ula Ditch, the discharge measured at site E7 represented the total discharge in Kaua 'ula Stream upstream from the diversion at partial-record site $\mathrm{L} 12$, and was between the $\mathrm{Q}_{95}$ and $\mathrm{Q}_{85}$ discharges (table 6, site L12). On September 3, the development tunnel on the north fork tributary contributed about 16 percent $\left(0.60 \mathrm{ft}^{3} / \mathrm{s}\right)$ of the flow measured at the uppermost site (E1), assuming discharge from the development tunnel is water that would otherwise have naturally discharged to Kaua 'ula Stream. On September 17, the total flow contributed from the north and south fork tributaries was $4.60 \mathrm{ft}^{3} / \mathrm{s}$, which was computed by combining the discharges measured at sites E2 and E3. In the 0.59-mi reach downstream from the confluence of the north and south fork tributaries, Kaua'ula Stream gained $0.54 \mathrm{ft}^{3} / \mathrm{s}$ of flow, representing a 12-percent seepage gain from the discharge at the confluence of the tributaries. The Kaua 'ula Ditch intake diverted all of the flow in the stream, which was about $4.80 \mathrm{ft}^{3} / \mathrm{s}$ of flow. About $20 \mathrm{ft}$ downstream from the Kaua 'ula Ditch intake, a flow of $0.060 \mathrm{ft}^{3} / \mathrm{s}$ was returned to the stream by an open-release valve that remained opened at the same height for both surveys. Based on the discharges measured at sites E4 and E5, the 0.72-mi stream reach between the sites lost $0.34 \mathrm{ft}^{3} / \mathrm{s}$ of flow, representing a 7-percent seepage loss. All of the flow returned downstream from the Kaua 'ula Ditch intake was lost in the 260-ft stream reach downstream from the point of flow release.

On September 16, the $0.75 \mathrm{mi}$ of Kaua 'ula Ditch lost about 15 percent of its flow of $5.59 \mathrm{ft}^{3} / \mathrm{s}$ measured near the intake (site E7). From the remaining $4.73 \mathrm{ft}^{3} / \mathrm{s}$ of flow at the Kaua 'ula Ditch tunnel exit (site E8), $0.12 \mathrm{ft}^{3} / \mathrm{s}$ of flow was returned for taro cultivation at site E9 and $1.04 \mathrm{ft}^{3} / \mathrm{s}$ of flow was returned to the stream by the siphon at site E11. About $3.25 \mathrm{ft}^{3} / \mathrm{s}$ of flow was measured in Kaua'ula Ditch at site E10 that eventually discharged into the Kaua 'ula Reservoir. A reduction of $0.32 \mathrm{ft}^{3} / \mathrm{s}$ of flow between sites E8 and E10 in Kaua 'ula Ditch was attributed to flow diverted by a 4-inch Maui County pipeline, flow diverted to a filter box station that was part of the Kaua'ula diversion system, and seepage losses within the ditch. On September 2, the 0.38-mi stream reach downstream from the Kaua'ula siphon return flow (site E11) lost a flow of $0.43 \mathrm{ft}^{3} / \mathrm{s}$ to the subsurface, representing a 28-percent seepage loss from the discharge at site E11. On September 17, about $0.20 \mathrm{ft}^{3} / \mathrm{s}$ of flow was returned to the stream at site E13 from an intake that provided water for small-scale agriculture within the valley. All of this flow was lost to the subsurface, leaving the stream dry at site E14 about $900 \mathrm{ft}$ downstream from the return flow.

\section{Launiupoko Stream}

No seepage run was conducted on Launiupoko Stream as part of this study because the stream below the diversion intake was dry and a temporary release of flow from the diversion intake could not be coordinated during the study 


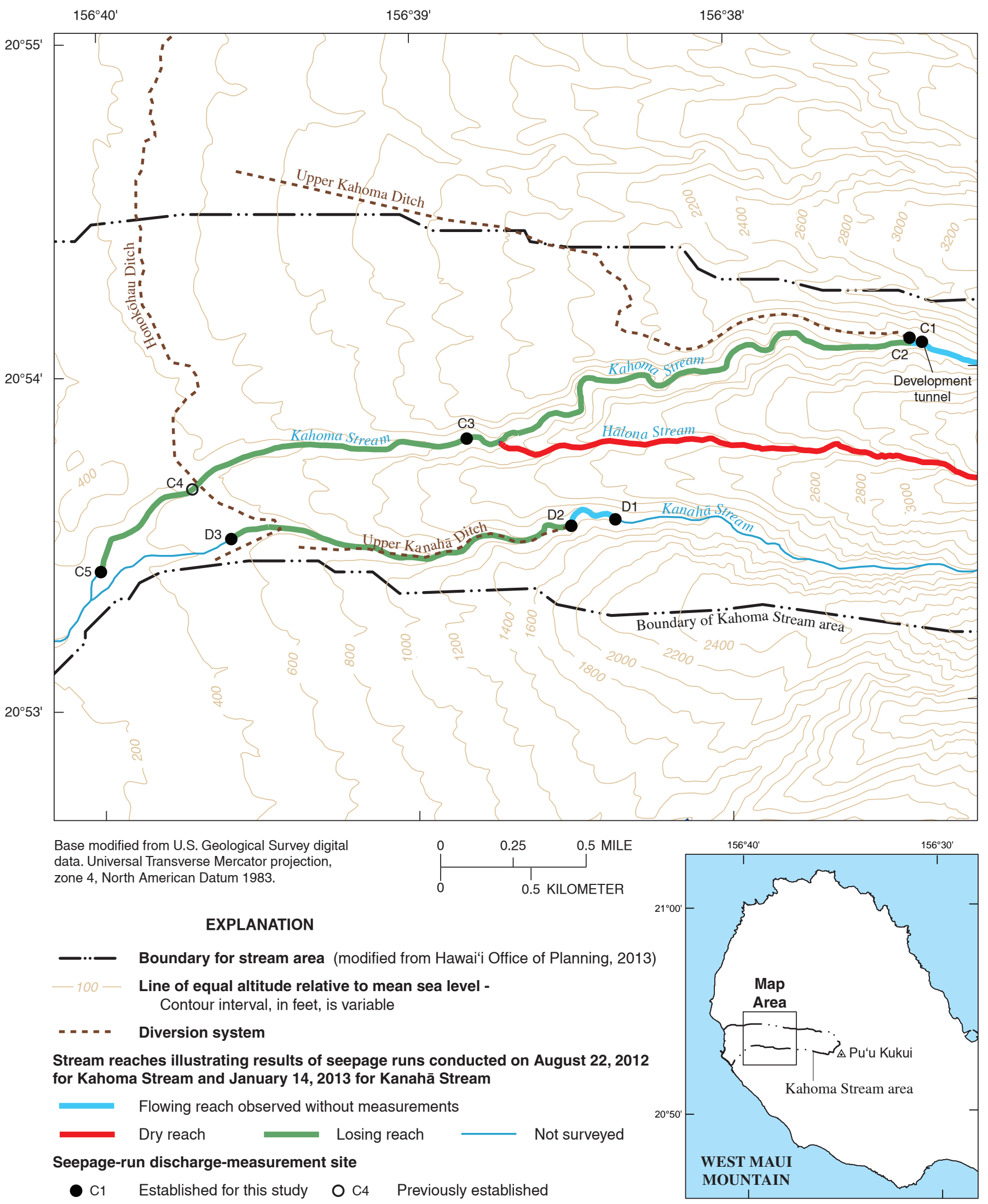

Figure 11. Map of seepage-run measurement sites for Kahoma and Kanahā Streams, west Maui, Hawai'i. 


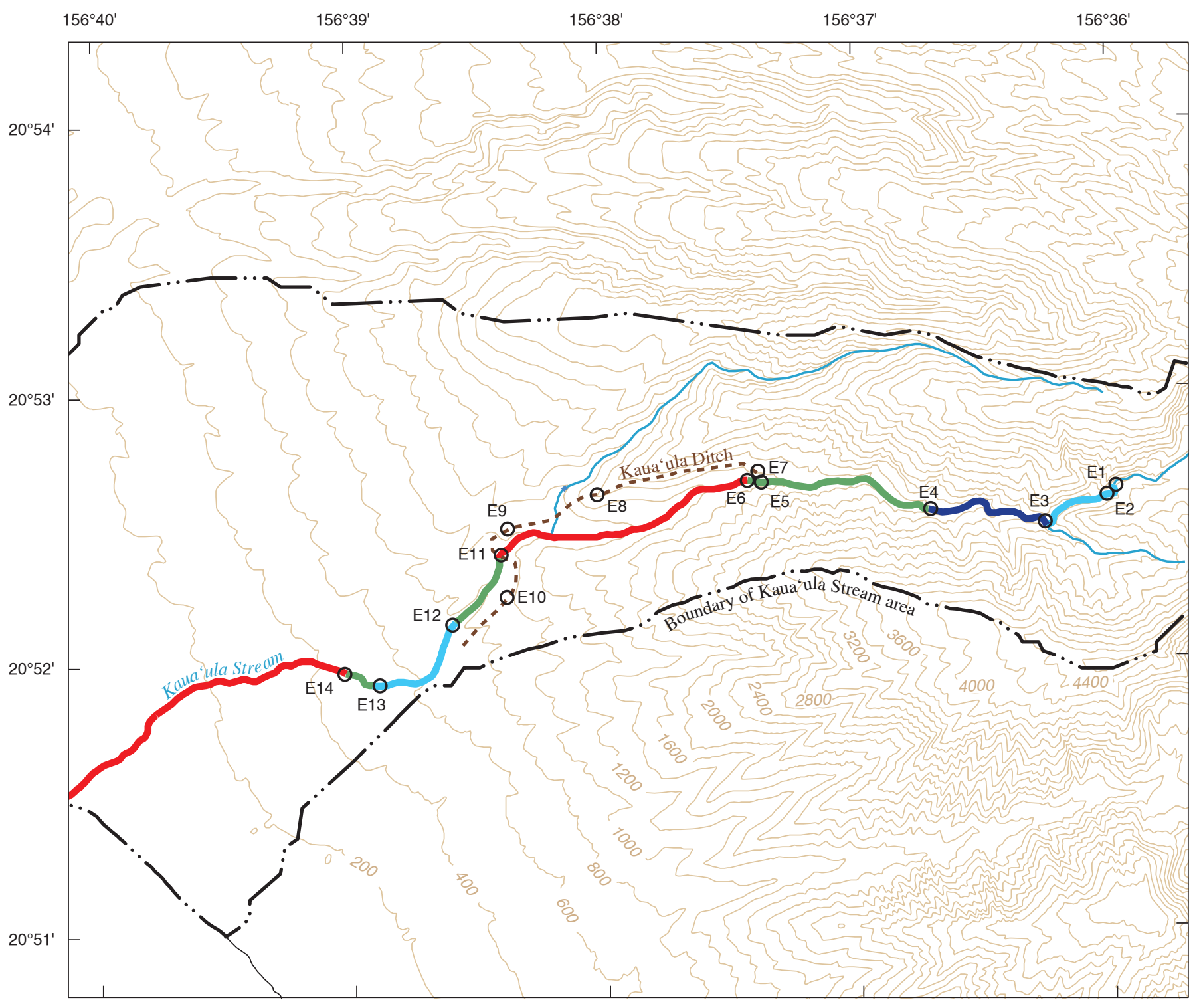

Base modified from U.S. Geological Survey digital data. Universal Transverse Mercator projection, zone 4, North American Datum 1983.

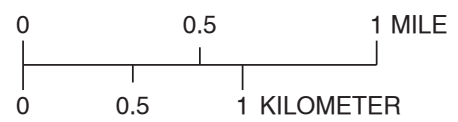

\section{EXPLANATION}

-..- Boundary for stream area (modified from Hawai'i Office of Planning, 2013)

- 100 - Line of equal altitude relative to mean sea level Contour interval, in feet, is variable

\section{- - - - - Diversion system}

Stream reaches illustrating results of September $2-3$ and 16-17, 2008 seepage runs

Flowing reach observed without measurements

$\begin{array}{lll}\text { Gaining reach } & \text { Losing reach } \\ \text { Dry reach } & \text { Not surveyed }\end{array}$

Seepage-run discharge-measurement site

O E1 Previously established

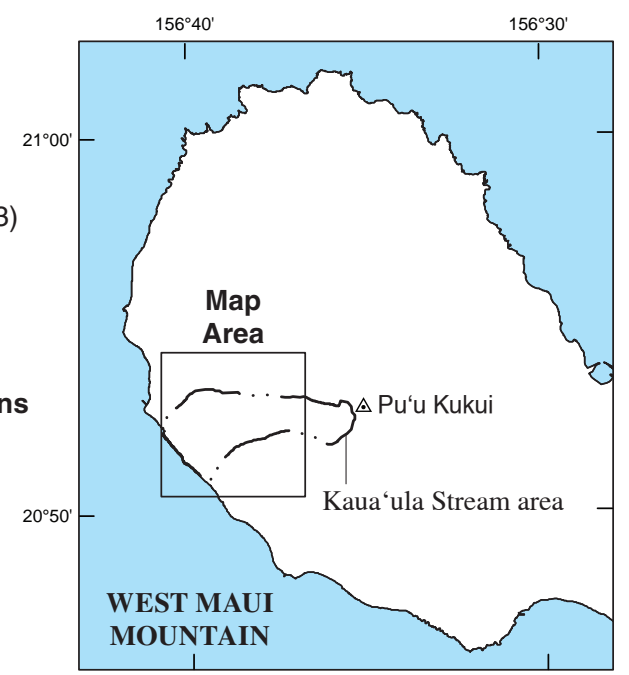

Figure 12. Map of seepage-run measurement sites for Kaua'ula Stream, west Maui, Hawai'i. 
period. A previous seepage run was conducted on Launiupoko Stream on February 28, 1967 (table 16), and all the discharge measurements were made upstream from the diversion intake. During that seepage run, the development tunnel at an altitude of 1,440 ft (sites F2 and F1, fig. 13) contributed about 10 percent of the flow in the stream. The $0.30-\mathrm{mi}$ reach between the development tunnel and the Launiupoko Ditch intake gained $0.34 \mathrm{ft}^{3} / \mathrm{s}$ of flow, representing a 30-percent seepage gain from the total stream discharge downstream of the development tunnel.

\section{Olowalu Stream}

Available seepage-run measurements for Olowalu Stream show a generally losing stream downstream of the upper intake under low-flow conditions. Under natural-flow conditions, the stream is estimated to flow to the ocean at least 95 percent of the time assuming (1) a total seepage loss of $1.51 \mathrm{ft}^{3} / \mathrm{s}$ in the stream reach between the upper intake and site $\mathrm{G} 9$, and (2) a seepage-loss rate of $1.43\left(\mathrm{ft}^{3} / \mathrm{s}\right) / \mathrm{mi}$ in the stream reach between site G9 and the stream mouth.

On February 13, 2013, seepage-run measurements were made at five measurement sites (G1, G3, G4, G5 and G9) on Olowalu Stream located between stream-channel altitudes of 120 and $560 \mathrm{ft}$, two ditch-flow measurement sites (G12 and G14) located in upper Olowalu Ditch, and one measurement site (G8) that measured taro return flow into the stream (table 16, fig. 14). Site G1 was also partial-record site L14 in this study (table 3 , fig. 1). The seepage run was conducted during diverted conditions with partial release of flow into the stream through ditch leakage. Flow in Olowalu Stream at the measurement sites ranged from 4.23 to $9.18 \mathrm{ft}^{3} / \mathrm{s}$. Olowalu Stream discharge at site G1 was greater than medianflow conditions (table 6 , site L14) during the seepage run, which indicated possible occurrence of runoff in the stream. However, stage readings collected during the seepage run showed minimal changes in stage. The 0.14-mi stream reach between the uppermost site (G1) and the upper intake gained $0.72 \mathrm{ft}^{3} / \mathrm{s}$ of flow, representing an 8-percent seepage gain from the discharge measured at the uppermost site. The upper Olowalu Ditch intake captured all of the flow in the stream, which was $9.18 \mathrm{ft}^{3} / \mathrm{s}$ measured at site $\mathrm{G} 3$, leaving the stream reach immediately downstream from the upper intake dry. A large amount of the diverted water was observed to flow from Olowalu Ditch into the stream about $400 \mathrm{ft}$ downstream from the upper intake (fig. 15). Based on the discharge measured in the stream downstream from this large leakage (site G4), about 46 percent of the diverted flow was returned from the ditch to the stream through this leakage. An additional seepage loss of $0.9 \mathrm{ft}^{3} / \mathrm{s}$ may have occurred in the upper ditch between the intake and the large ditch leakage.

Downstream from the large ditch leakage, water was seen leaking from Olowalu Ditch into the stream at multiple locations. Two measurements (sites G12 and G14) were made in the upper ditch to quantify the amount of losses from the ditch. Based on these measurements, the 0.87-mi reach of the upper ditch between these sites lost $1.84 \mathrm{ft}^{3} / \mathrm{s}$ of flow, representing a 45-percent loss from the discharge measured at the beginning of the ditch at site G12. Measurements made in the stream at sites G4 and G5 indicated a gain of $0.89 \mathrm{ft}^{3} / \mathrm{s}$, representing a 21-percent increase in flow. Assuming the loss of $1.84 \mathrm{ft}^{3} / \mathrm{s}$ of flow from the ditch was returned to the stream, the stream reach between sites G4 and G5 had a net loss in flow of $0.95 \mathrm{ft}^{3} / \mathrm{s}$. Some of the diverted water from upper Olowalu Ditch was used for taro cultivation. About $0.063 \mathrm{ft}^{3} / \mathrm{s}$ of flow was returned from the taro lo ' $\mathrm{i}$ (terraces) to the stream at site G8. With the taro return flow taken into consideration, the 0.61 -mi stream reach downstream from site G5 lost $0.56 \mathrm{ft}^{3} / \mathrm{s}$ of flow, representing an 11-percent seepage loss from the discharge measured at site G5. This seepage run (February 13, 2013) was conducted under higher flow conditions to ensure an adequate amount of water remained in the stream downstream from the diversion while maintaining adequate flow in the ditch for downstream use. Because only about half of the flow remained in the stream downstream from the diversion, streamflows in the lower reaches are representative of low-flow conditions.

Results of the February 2013 seepage run relating to reaches downstream from the upper intake are consistent with those from previous seepage runs (table 16). On August 15, 2008, seepage-run measurements were made under regulated-flow conditions and the upper ditch was in disrepair, leaking in many areas and releasing a large amount of flow back into the stream. The 0.8 -mi reach of the ditch between the intake and site G13 lost a flow $1.89 \mathrm{ft}^{3} / \mathrm{s}$, which is similar to the amount lost during the February 2013 seepage run. Flow was observed in some reaches downstream of the upper intake. Downstream of all the ditch leaks, which was about $500 \mathrm{ft}$ upstream from the taro return flow at site $\mathrm{G} 8,0.3 \mathrm{ft}^{3} / \mathrm{s}$ of flow was measured in the stream. The seepage run on February 28, 1967, was conducted when the daily mean discharge at the index station on Honokōhau Stream was at the $\mathrm{Q}_{3}$ discharge for base period 1984-2013. Because of unstable-flow conditions that occurred during the seepage run, the results of that seepage run are not representative of the magnitude of seepage losses in the stream. 


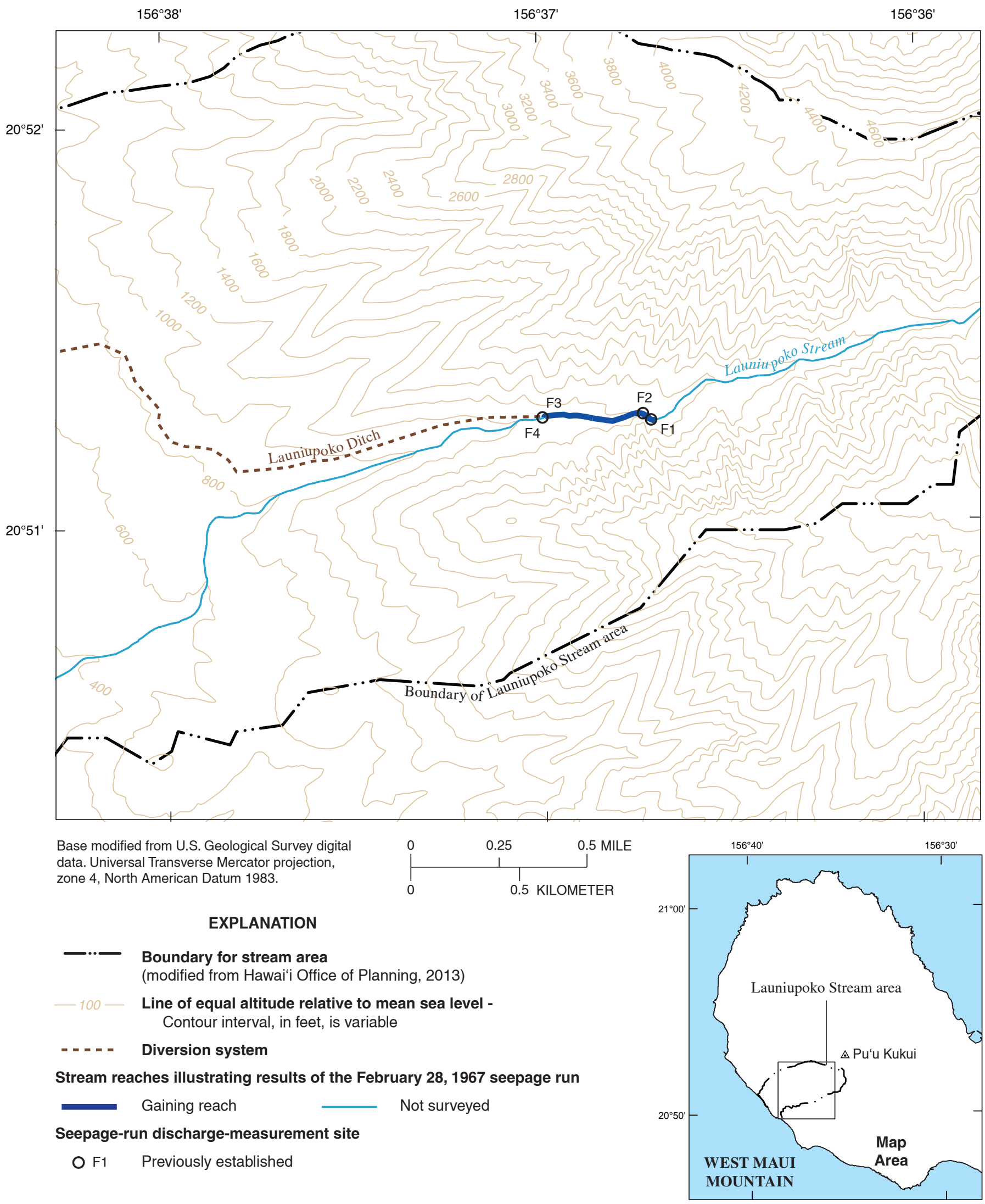

Figure 13. Map of seepage-run measurement sites for Launiupoko Stream, west Maui, Hawai'i. 


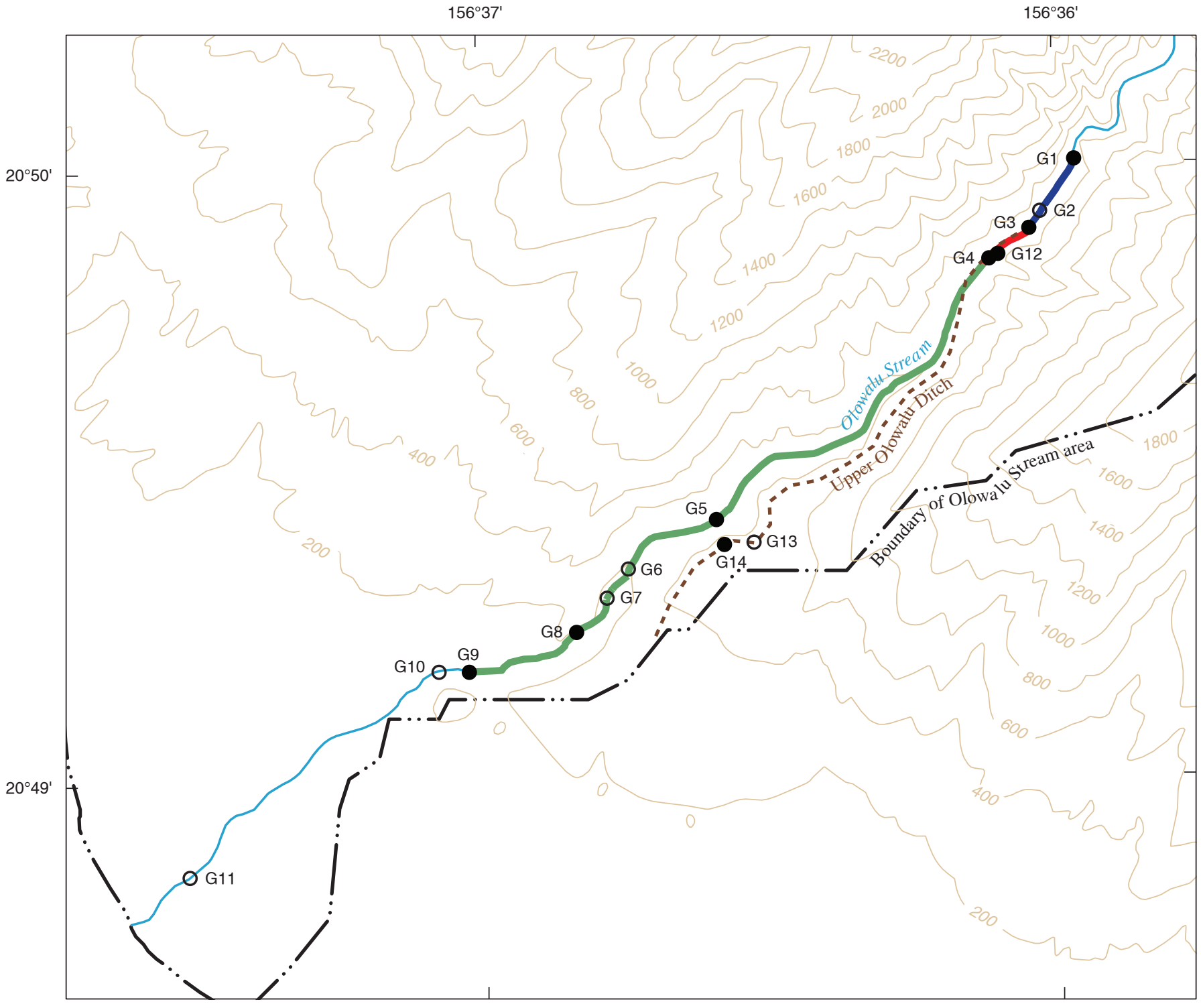

Base modified from U.S. Geological Survey digital data. Universal Transverse Mercator projection, zone 4, North American Datum 1983.

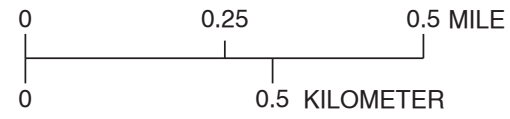

\section{EXPLANATION}

Boundary for stream area (modified from Hawai'i Office of Planning, 2013)

- 100 - Line of equal altitude relative to mean sea level Contour interval, in feet, is variable

\section{- - - - Diversion system}

Stream reaches illustrating results of the February 13, 2013 seepage run

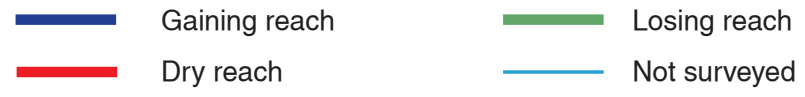

\section{Seepage-run discharge-measurement site}

- G1 Established for this study O G2 Previously established

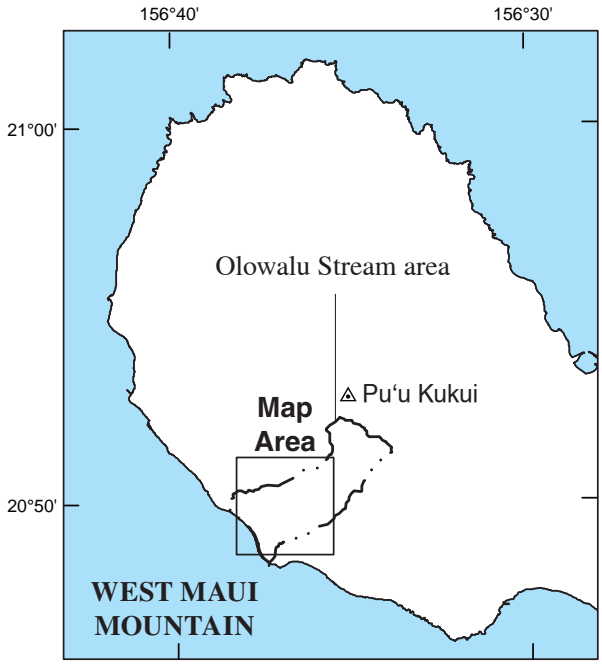

Figure 14. Map of seepage-run measurement sites for Olowalu Stream, west Maui, Hawai'i. 


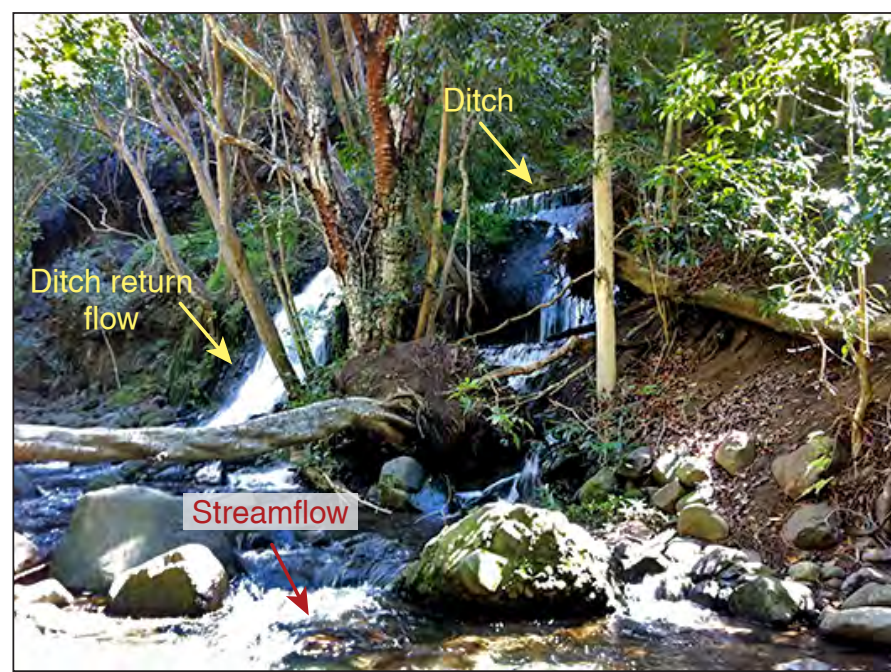

Figure 15. Photograph showing leakage from Olowalu Ditch into Olowalu Stream, west Maui, Hawai'i, during the seepage run on February 13, 2013.

\section{Ukumehame Gulch}

Seepage-run measurements available for Ukumehame Gulch show variable seepage flows between altitudes of 100 and $410 \mathrm{ft}$, and mauka to makai flow at least 95 percent of the time under natural-flow conditions. On March 14, 2013, discharges were measured at five sites $(\mathrm{H} 1, \mathrm{H} 2, \mathrm{H} 4, \mathrm{H} 5$, and H10) on Ukumehame Gulch located between altitudes of 100 and $410 \mathrm{ft}$ (sites H10 and H1, table 16), one site (H3) at the start of a taro ditch, and two sites ( $\mathrm{H} 7$ and $\mathrm{H} 8)$ that measured taro return flow into the stream (table 16, fig. 16). The uppermost site (H1), also partial-record site L15 in this study (table 3, fig. 1), was located at the inactive continuousrecord streamflow-gaging station 16647000 and the lowermost site (H10) was located at an altitude of $100 \mathrm{ft}$. The seepage run was conducted during diverted-flow conditions when streamflow was diverted for taro cultivation. The Ukumehame Ditch intake was not diverting water during the seepage run. Streamflow at the measurement sites ranged from 3.30 to $4.18 \mathrm{ft}^{3} / \mathrm{s}$ and Ukumehame Gulch discharge at site $\mathrm{H} 1$ was at the $\mathrm{Q}_{75}$ discharge (table 6, site L15). In the 0.44-mi reach upstream from the taro diversion at site $\mathrm{H} 3$, the stream gained $0.33 \mathrm{ft}^{3} / \mathrm{s}$ of flow, representing a 9-percent seepage gain from the discharge measured at the uppermost site (H1). During the seepage run, about $0.73 \mathrm{ft}^{3} / \mathrm{s}$ of flow (17 percent of the flow measured at site $\mathrm{H} 2$ ) was diverted into the taro ditch, leaving $3.45 \mathrm{ft}^{3} / \mathrm{s}$ of flow in the stream downstream of the taro diversion intake. Between the taro diversion intake (site H3) and the Ukumehame Ditch intake near site H4, the stream lost $0.08 \mathrm{ft}^{3} / \mathrm{s}$ of flow. Considering that multiple leakages from the taro ditch into the stream were observed in this reach, the actual seepage loss likely was greater than the measured seepage loss. Discharges at sites H4 and H5 were measured to confirm that no water was being diverted into Ukumehame Ditch. Based on these measurements, the $60-\mathrm{ft}$ reach between the sites gained $0.38 \mathrm{ft}^{3} / \mathrm{s}$ of flow, representing an 11-percent gain from the discharge measured at site H4. Downstream from the
Ukumehame Ditch intake, a flow of $0.14 \mathrm{ft}^{3} / \mathrm{s}$ was returned to the stream from the taro lo' $\mathrm{i}$ at sites $\mathrm{H} 7$ and H8, which was 19 percent of the diverted amount. With the taro return flows taken into consideration, the net loss in the $0.63-\mathrm{mi}$ stream reach downstream from the Ukumehame Ditch was $0.59 \mathrm{ft}^{3} / \mathrm{s}$, representing a 16-percent seepage loss from the discharge measured at site $\mathrm{H} 5$.

Results of the March 2013 seepage run are inconsistent with those of previous seepage runs (table 16). On September 20, 2006, when flow at site $\mathrm{H} 1$ was at the $\mathrm{Q}_{90}$ discharge (table 6, site L15), a 4-percent loss of flow was measured between sites H1 and H2. Because the Ukumehame Ditch diversion intake was diverting water during the seepage run, only $0.91 \mathrm{ft}^{3} / \mathrm{s}$ of flow remained at site H9. Between sites H9 and the stream mouth (site H11), the stream lost 31 percent of its flow. On May 25, 2006, flow at station 16604500 on 'Īao Stream was at the $\mathrm{Q}_{45}$ discharge for base period 1984-2013. The stream gained 19 percent of its flow between the Ukumehame Ditch intake (site H6) and site H9 and lost 14 percent of its flow between sites $\mathrm{H} 9$ and the stream mouth. The amount of water diverted at the taro intake was $0.80 \mathrm{ft}^{3} / \mathrm{s}$ and the amount of water diverted at the Ukumehame Ditch intake was $0.38 \mathrm{ft}^{3} / \mathrm{s}$.

\section{Limitations of Approach}

Flow-duration discharges at partial-record sites in the Lahaina study area were estimated with graphical-correlation and MOVE. 1 record-augmentation techniques. For this study, accuracy of the estimates was largely dependent on (1) the strength of the correlation between concurrent discharges at the index stations and partial-record sites; (2) the number of discharge measurements at the partial-record sites that were available for use in record-augmentation analysis; (3) the accuracy of the individual discharge measurements; (4) the range of flow conditions represented by the measurements; and (5) the representativeness of the selected base period relative to long-term conditions.

For Honolua and Kahoma Streams, the graphical fits were plotted through as many of the data points as possible to accurately represent the correlation between concurrent discharges at the index station and partial-record sites. The arithmetic plots for Honolua and Kahoma Streams (fig. 7) show distinguished shapes and generally exhibit minimal spread around the graphical fits. The plot for Honolua Stream indicates an outlier that has little influence on the graphical fit.

The MOVE.1 regression models provide relatively accurate flow-duration estimates; although the coefficients of efficiency $(E)$ indicate that the predictive ability of the models tends to decrease slightly from the southern to northern parts of the study area (table 5). In general, correlations between concurrent discharges at the index stations and partial-record sites are fairly strong for Honokōwai, Kanahā, Kaua 'ula, Launiupoko, and Olowalu Streams, and Ukumehame Gulchas indicated by the correlation coefficients $(r)$ ranging from 0.85 to 0.96 . 


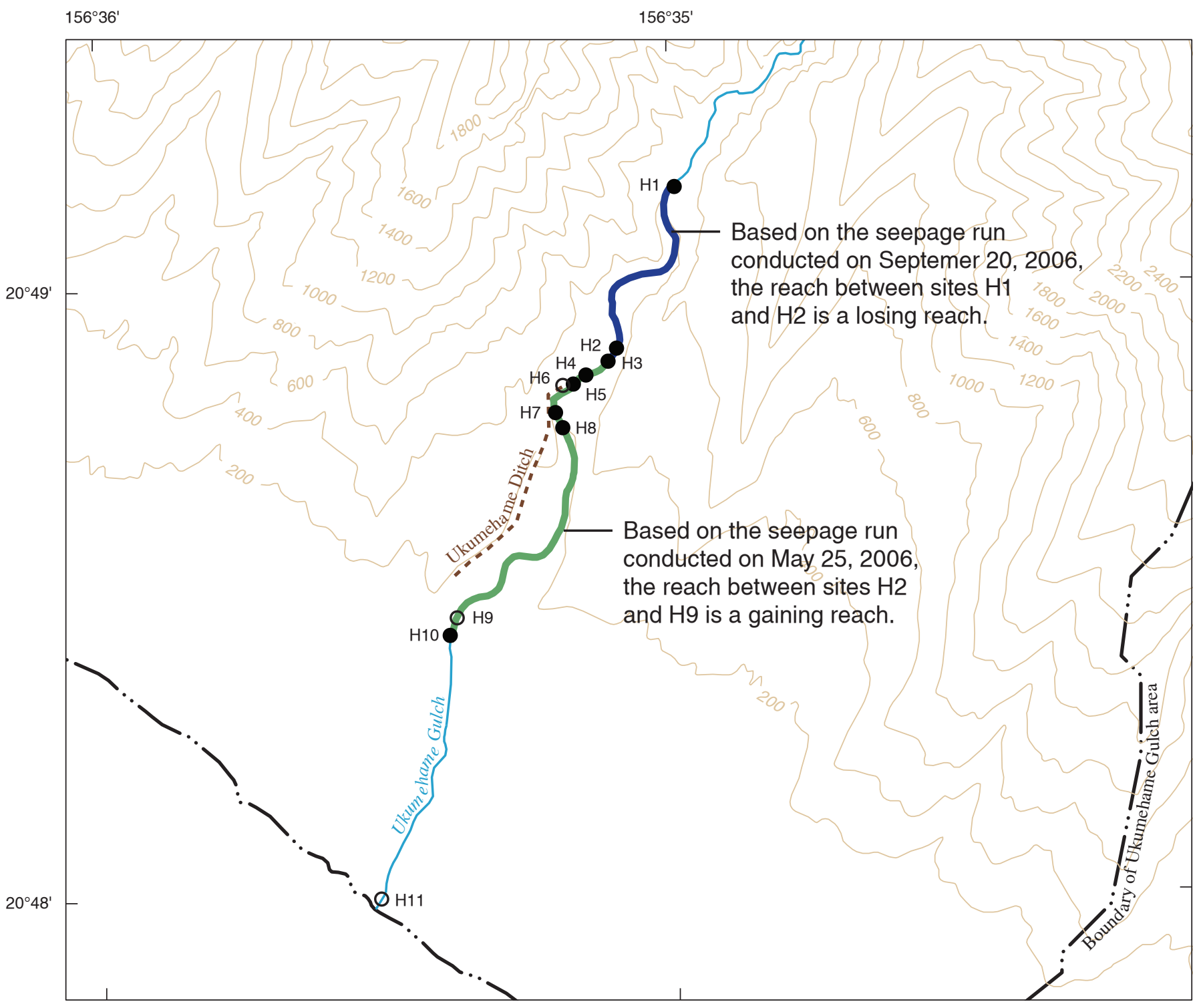

Base modified from U.S. Geological Survey digital data. Universal Transverse Mercator projection, zone 4, North American Datum 1983.
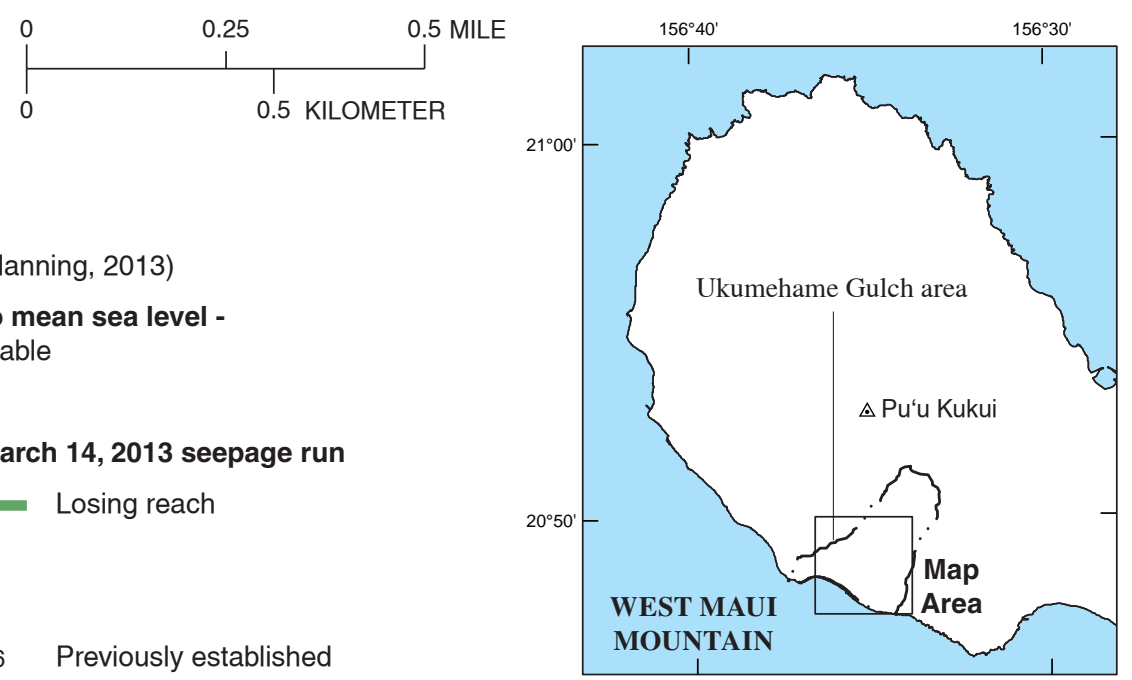

EXPLANATION

Boundary for stream area (modified from Hawai'i Office of Planning, 2013)

- 100 - Line of equal altitude relative to mean sea level Contour interval, in feet, is variable

- - - - - Diversion system

Stream reaches illustrating results of the March 14, 2013 seepage run

Gaining reach Losing reach

Not surveyed

Seepage-run discharge-measurement site

- H1 Established for this study $\mathrm{OH}$ Previously established

Figure 16. Map of seepage-run measurement sites for Ukumehame Gulch, west Maui, Hawai'i. 
The statistical relations used to estimate low-flow duration discharges were generally developed based on 9 to 12 measurements made at the partial-record sites. For Ukumehame Gulch, the relation was based on 15 discharges, and most of them were derived from a rating curve. A rating curve is typically developed and verified using a minimum of 10 measurements per year and the measurements should cover a range of streamflow conditions to minimize extrapolation of the data beyond the range of measured discharges, which typically occurs at the upper and lower ends of the curve (Rantz and others, 1982, p. 285-286). The rating curve for Ukumehame Gulch was constructed from 13 measurements collected in 2012, and the discharges represented low- and high-flow conditions, which eliminated the need for extrapolation. The curve accurately characterized the stagedischarge relation at the partial-record site because a majority of the measurements used to construct the rating curve were within \pm 5 percent of the curve. The percentage departure of the measured discharge collected near the end of the study on November 21, 2013, from the stage discharge is 2 percent; therefore, the rating curve can be applied with high confidence to 2013 flow conditions. Major channel and control changes that would require reestablishing the stage-discharge relation at the measurement site did not occur during the study period. However, minor channel and control changes that could not be easily detected during field inspections may affect the stagedischarge relation, but the effects are assumed to be minimal.

Factors that could contribute to discharge-measurement errors include, but are not limited to, the condition of the measuring instrument and instrument error, characteristics of the measurement cross section, spacing and number of observation verticals in a cross section, changing stage during the measurement, flow depth and velocity, and environment (Rantz and others, 1982, p. 179-180).

Low-flow characteristics for Launiupoko Stream were determined from model estimates of flow-duration discharges on Ukumehame Gulch instead of flow-duration discharges computed from records at a long-term continuous-record station. The discharge measurements on Ukumehame Gulch correlated well with the concurrent daily mean discharges on 'Īao Stream; however, the same correlation could not be assumed for Launiupoko Stream because of differing hydrogeologic attributes associated with a smaller drainage basin, headwaters situated at lower altitudes, and fewer tributary sources in the stream network. Inaccuracies in the Launiupoko Stream estimates could be compounded from potential errors in the discharge measurements for Launiupoko Stream and Ukumehame Gulch, and from potential errors in the flow-duration discharge estimates for Ukumehame Gulch. Efforts were made to reduce errors by developing a rating curve for Ukumehame Gulch, which allowed more measurements to be made available at Ukumehame Gulch for use in record augmentation. Given the fairly accurate model estimates for Ukumehame Gulch, the flow-duration discharges estimated for Launiupoko Stream are considered satisfactory.
Using the gaging station on Hālawa Stream, Moloka'i, as an index station for the partial-record site on Kanahā Stream raises the question of hydrologic similarity because streamflows in these two basins are not generated from the same source. Consequently, hydrologic conditions at the index stream could not be observed when measuring discharges at the partial-record site. The lack of adequate rainfall data for Moloka'i limited the ability to determine locally specific rainfall and (or) occurrence of storm events on the island. These are factors that affect the ability to collect and interpret data that are used to estimate streamflow characteristics. In regards to the accuracy of the flow-duration estimates, Eng and others (2011) showed that the MOVE.1 technique is not significantly affected by the similarity of basin attributes and proximity of the index streamgage to the partial-record site. Based on the regression statistics for the MOVE. 1 results (table 5), the flow-duration estimates for Kanahā Stream are considered satisfactory in terms of the correlation coefficient $(r)$, the root mean square error (RMSE), and a modified NashSutcliff coefficient of efficiency $(E)$.

Flow-duration statistics at index stations and partialrecord sites are applicable to the base period over which they have been computed. For this study, 30 years of streamflow data (water years 1984-2013) were available at the index stations. Flow-duration statistics at the index station on Honokōhau Stream provide estimates of streamflow characteristics at the partial-record sites that are representative of long-term flow conditions because significant trends in low streamflow were not detected during 1943-2008, and lowflow duration statistics computed from the base-period record are similar to those computed from the longer-term record (table 4). Whether the statistics at the index station on Hālawa Stream provide estimates of streamflow characteristics at the partial-record site on Kanahā Stream that are representative of long-term streamflow conditions is less certain because of the significant downward trends in low streamflows detected during 1943-2008. Extrapolation of flow-duration statistics to future conditions assumes that the hydrologic condition that occurred during the base period will continue in the future.

Seepage gains and losses along a reach were computed as the difference between the upstream and downstream discharges, excluding any tributary inflows and diversions of water within the reach. Considering the potential error in the seepage-run measurements, the estimated seepage gains and losses may not accurately reflect the true gains and losses within a reach. Measured tributary inflows and diversions of water introduce additional errors in the seepage estimates, and this is especially apparent in the Olowalu and Kaua 'ula Stream seepage runs. Additional measurements were made during the Olowalu Stream seepage run to quantify the amount of water diverted and the amount of water that leaked back into the stream from Olowalu Ditch. Because the ditch leaked in many areas, measurements were made in the ditch to quantify the amount of losses, which may not equate to the amount that the stream potentially gained from the ditch. Similarly, the Kaua 'ula Stream seepage run consisted of multiple discharge 
measurements that were made to quantify the amount of water diverted into Kaua 'ula Ditch and the amount of return flows from taro cultivation. Errors associated with each additional measurement made during a seepage run to quantify inflows and outflows collectively decrease the accuracy of the seepage estimates.

\section{Suggestions for Future Work}

Additional discharge measurements at the partial-record sites would increase the level of confidence of the estimated flow-duration discharges, especially for Honokōwai, Kaua 'ula, and Kanahā Streams. Some of the measurements for Launiupoko Stream were collected between June 6 and August 7, 2012, when continuous data at the index station on 'Iao Stream were unavailable. Consequently, less data were available to establish a statistical relation between 'Īao and Launiupoko Streams. Additional measurements on Launiupoko Stream combined with available concurrent daily mean discharges on 'Iao Stream would help to define the statistical relation and improve the accuracy of the flow-duration discharge estimates.

The ephemeral streams of Pāpua Gulch, Honokahua Stream and its tributary Mokupe 'a Gulch, Kahana Stream, and Wahikuli Gulch and its tributary Hāhākea Gulch were determined to be dry at least 50 percent of the time based on the 4-7 observations made at each site during a range of lowand high-flow conditions at the index station. Certainty in the low-flow characteristics of these ephemeral streams could be increased by conducting streambed temperature analysis in conjunction with logistic regression methods. Streambed temperature analysis is a robust and inexpensive method of monitoring the spatial and temporal variations in streamflow of ephemeral streams (Constantz and others, 2001) because diurnal temperature variations in a dry streambed are generally greater than variations in a flowing stream. Streambed temperature data and data from the index station can be used in logistic regression methods to estimate the probability of zero flow at a partial-record site. The logistic regression method is a probabilistic statistical method that is commonly used to predict a discrete or binary response, such as flow or no flow, from a set of continuous independent variables, such as streamflow at an index station (Helsel and Hirsch, 2002). The logistic regression method could not be applied in this study because of the limited discharge data collected at the ephemeral streams.

\section{Summary and Conclusions}

Over the last century, surface water in the Lahaina District of west Maui, Hawai ' $i$, was used primarily for largescale agriculture. Beginning in the late 1800s, Pioneer Mill cultivated sugarcane in the Lahaina area, and Maui Land \& Pineapple Company cultivated pineapple and raised livestock in the Nāpili area. In the Lahaina District, sugarcane cultivation ceased in 1999, and pineapple cultivation ceased in 2009. Parts of the diversion systems that transported water to the plantations were in operation during the study period (2012-13) and continue to support agricultural, municipal, and domestic needs.

The State of Hawai 'i Commission on Water Resource Management establishes instream-flow standards to describe flows necessary to protect the public interest in the stream with consideration of current and future water uses. Surfacewater resources in an area must be quantified to effectively manage water resources for competing uses. The purpose of this study was to characterize streamflow availability under low-flow conditions for streams in the Lahaina District, west Maui, Hawai'i, which included Honolua Stream and tributary Pāpua Gulch, Honokahua Stream and tributary Mokupe'a Gulch, Kahana Stream, Honokōwai Stream, Wahikuli Gulch and tributary Hāhākea Gulch, Kahoma Stream and tributary Kanahā Stream, Kaua ‘ula Stream, Launiupoko Stream, Olowalu Stream, and Ukumehame Gulch. The results of this study can be used to assist in the determination of technically defensible instream-flow standards for the study-area streams.

Low-flow characteristics, under natural (unregulated) streamflow conditions, of the study-area streams were determined by analyzing historical and current streamflow data from continuous-record streamflow-gaging stations and miscellaneous sites, and additional data collected at partialrecord sites. Fifteen partial-record sites were established, mainly upstream from existing surface-water diversions, where discharge measurements were made between February 2012 and November 2013. Continuous-record stations on Honokōhau Stream, Waihe'e River, 'Īao Stream, and Hālawa Stream (island of Moloka'i) were selected as potential index stations and used to estimate $\mathrm{Q}_{95}$ to $\mathrm{Q}_{50}$ flow-duration discharges using the graphical-correlation and MOVE.1 recordaugmentation techniques.

The estimated natural $\mathrm{Q}_{50}$ (median or 50-percent) discharge at Honolua Stream upstream from the intake is $3.8 \mathrm{ft}^{3} / \mathrm{s}$ and the stream is estimated to run dry at the $\mathrm{Q}_{90}$ (90-percent) discharge. At the confluence of Amalu and Kapāloa Streams on Honokōwai Stream, the natural $\mathrm{Q}_{95}$ to $\mathrm{Q}_{50}$ discharges (discharges that are equaled or exceeded from 95 to 50 percent of the time) range from 3.4 to $5.4 \mathrm{ft}^{3} / \mathrm{s}$. At Kahoma Stream upstream from the upper intake, the natural $\mathrm{Q}_{95}$ to $\mathrm{Q}_{50}$ discharges range from 2.0 to $5.8 \mathrm{ft}^{3} / \mathrm{s}$. Flow does not vary greatly under low-flow conditions at Kanahā Stream upstream from the upper intake, as the natural $\mathrm{Q}_{95}$ to $\mathrm{Q}_{50}$ discharges range from 4.0 to $4.9 \mathrm{ft}^{3} / \mathrm{s}$. At Kaua 'ula Stream upstream from the intake, the natural $\mathrm{Q}_{95}$ to $\mathrm{Q}_{50}$ discharges range from 4.8 to $9.5 \mathrm{ft}^{3} / \mathrm{s}$. At Launiupoko Stream, $100 \mathrm{ft}$ upstream from the intake, the natural $\mathrm{Q}_{95}$ to $\mathrm{Q}_{50}$ discharges are relatively low and range from 0.34 to $0.47 \mathrm{ft}^{3} / \mathrm{s}$. At Olowalu Stream, $800 \mathrm{ft}$ upstream from the upper intake, the natural $\mathrm{Q}_{95}$ to $\mathrm{Q}_{50}$ discharges range from 3.1 to $6.1 \mathrm{ft}^{3} / \mathrm{s}$. At Ukumehame Gulch, 0.5 mi upstream from the intake, the natural $\mathrm{Q}_{95}$ to $\mathrm{Q}_{50}$ discharges range from 3.0 to $5.0 \mathrm{ft}^{3} / \mathrm{s}$. The six ephemeral streams 
that are observed to remain dry at least 50 percent of the time include Pāpua Gulch, Honokahua Stream and its tributary Mokupe'a Gulch, Kahana Stream, and Wahikuli Gulch and its tributary Hāhākea Gulch.

The discharge estimates are applicable to the 30-year base period-water years 1984 to 2013 - over which they have been computed. Based on the MOVE.1 regression statistics and the range of discharges measured at the partial-record sites (which included the entire low-flow range of interest), the flow-duration discharge estimates at the partial-record sites are considered to be accurate and representative of long-term low-flow conditions. Additional discharge measurements will help to increase the level of confidence of the flow-duration discharge estimates at all the partial-record sites.

Seepage-run discharge measurements downstream from surface-water diversions, together with low-flow duration discharge estimates at the partial-record sites can provide information on natural streamflow availability in the lower stream reaches and indicate whether the streams support mauka to makai flow, which is important for assessing the biological potential of a stream to support native stream fauna. Seepage-run results from previous studies and from this study were analyzed to characterize streamflow gains and losses downstream from surface-water diversions. Gaining and losing reaches were determined by computing the difference between the upstream and downstream discharges, excluding any tributary inflows and diversions of water within the reach. Available seepage-run measurements show that the study-area streams are generally losing streams downstream from diversions. Measured seepage-loss rates ranged between 0.045 and $1.6\left(\mathrm{ft}^{3} / \mathrm{s}\right) / \mathrm{mi}$. Seepage gains mostly occurred upstream from diversions and the measured seepage-gain rates ranged between 0.75 and $5.1\left(\mathrm{ft}^{3} / \mathrm{s}\right) / \mathrm{mi}$; one short reach had a measured seepage-gain rate of $35\left(\mathrm{ft}^{3} / \mathrm{s}\right) / \mathrm{mi}$. Under naturalflow conditions, Honolua Stream is estimated to support mauka to makai (mountain to ocean) flow less than 80 percent of the time and Honokōwai Stream supports mauka to makai flow less than 50 percent of the time. Kahoma Stream flows continuously from the upper diversion intake to the confluence with Kanahā Stream between 85 and 90 percent of the time and Kanahā Stream is estimated to flow to the confluence with Kahoma Stream at least 95 percent of the time. Kaua 'ula Stream, Olowalu Stream, and Ukumehame Gulch are estimated to support mauka to makai flow at least 95 percent of the time.

\section{References Cited}

Bassiouni, Maoya, and Oki, D.S., 2013, Trends and shifts in streamflow in Hawai 'i, 1913-2008: Hydrologic Processes, v. 27 , no. 10 , p. $1484-1500$.

Blumenstock, D.I., and Price, Saul, 1967, Climates of the States-Hawaii: U.S. Department of Commerce, Climatography of the United States, no. 60-51, 27 p.

Cheng, C.L., and Wolff, R.H., 2012, Availability and distribution of low flow in Anahola Stream, Kaua 'i, Hawai 'i: U.S. Geological Survey Scientific Investigations Report 2012-5264, 32 p. [Also available at http://pubs.usgs.gov/ sir/2012/5264/.]

Constantz, Jim, Stonestrom, David, Stewart, A.E., Niswonger, Richard, and Smith, T.R., 2001, Analysis of streambed temperatures in ephemeral channels to determine streamflow frequency and duration: Water Resources Research, v. 37, no. 2, p. 317-328.

Eng, Ken, Kiang, J.E., Chen, Yin-Yu, Carlisle, D.M., and Granato, G.E., 2011, Causes of systematic over- or underestimation of low streamflows by use of index-streamgage approaches in the United States: Hydrological Processes, v. 25 , no. 14 , p. 2211-2220.

Engott, J.A., and Vana, T.T., 2007, Effects of agricultural landuse changes and rainfall on ground-water recharge in central and west Maui, Hawai 'i, 1926-2004: U.S. Geological Survey Scientific Investigations Report 2007-5103, 56 p. [Also available at http://pubs.usgs.gov/sir/2007/5103/.]

Fontaine, R.A., 1996, Evaluation of the surface-water quantity, surface-water quality, and rainfall data-collection programs in Hawaii, 1994: U.S. Geological Survey Water-Resources Investigations Report 95-4212, 125 p.

Fontaine, R.A., 2003, Availability and distribution of base flow in lower Honokohau Stream, Island of Maui: U.S. Geological Survey Water-Resources Investigations Report 03-4060, 37 p. [Also available at http://pubs.usgs.gov/wri/ wri034060/.]

Fontaine, R.A., 2012, Low-flow characteristics of streams under natural and diversion conditions, Waipi'o Valley, Island of Hawai ‘i, Hawai 'i: U.S. Geological Survey Scientific Investigations Report 2011-5118, 80 p. [Also available at http://pubs.usgs.gov/sir/2011/5118/.]

Fontaine, R.A., Wong, M.F., and Matsuoka, Iwao, 1992, Estimation of median streamflows at perennial stream sites in Hawaii: U.S. Geological Survey Water-Resources Investigations Report 92-4099, 37 p. 
Giambelluca, T.W., Chen, Qi, Frazier, A.G., Price, J.P., Chen, Yi-Leng, Chu, Pao-Shin, Eischeid, J.K., and Delparte, D.M., 2013, Online Rainfall Atlas of Hawai 'i: American Meteorological Society Bulletin, v. 94, no. 1, p. 313-316. [Also available at $h t t p: / / d x . d o i . o r g / 10.1175 / B A M S-D-11-00228.1$.

Giambelluca, T.W., and Schroeder, T.A., 1998, Climate, in Juvik, S.P., and Juvik, J.O., eds., Atlas of Hawai 'i (3d ed.): Honolulu, University of Hawai'i Press, p. 49-59.

Gingerich, S.B., 2005, Median and low-flow characteristics for stream under natural and diverted conditions, northeast Maui, Hawaii: U.S. Geological Survey Scientific Investigations Report 2004-5262, 72 p. [Also available at http://pubs.usgs.gov/sir/2004/5262/.]

Gingerich, S.B., and Engott, J.A., 2012, Groundwater availability in the Lahaina District, west Maui, Hawai' 1 : U.S. Geological Survey Scientific Investigations Report 2012-5010, 90 p. [Also available at http://pubs.usgs.gov/ $\operatorname{sir} / 2012 / 5010 /$.

Gingerich, S.B., and Wolff, R.H., 2005, Effects of surfacewater diversions on habitat availability for native macrofauna, northeast Maui, Hawaii: U.S. Geological Survey Scientific Investigations Report 2005-5213, 93 p. [Also available at http://pubs.usgs.gov/sir/2005/5213/.]

Granato, G.E., 2009, Computer programs for obtaining and analyzing daily mean streamflow data from the U.S. Geological Survey National Water Information System Web Site: U.S. Geological Survey Open-File Report 2008-1362, 123 p. [Also available at http://pubs.usgs.gov/ of/2008/1362/.]

Hawaii Department of Land and Natural Resources, 2001, Petitions to amend the interim instream flow standard for 27 Streams in east Maui: Hawai' $i$ Department of Land and Natural Resources, Commission on Water Resource Management Web page, accessed September 5, 2012, at http:// dlnr.hawaii.gov/cwrm/surfacewater/ifs/eastmauiiifs $1 /$.

Hawaii Department of Land and Natural Resources, 2004, Petitions to amend the interim instream flow standard for Waihee, North and South Waiehu, Iao and Waikapu Streams and their tributaries: Hawai 'i Department of Land and Natural Resources, Commission on Water Resource Management Web page, accessed September 5, 2012, at http:// hawaii.gov/dlnr/cwrm/act_PetitionNaWaiEha.htm. [Moved by time of publication; accessed May 14, 2014, at http:// dlnr.hawaii.gov/cwrm/surfacewater/ifs/nawaieha/.]

Hawai ' $\mathrm{i}$ Office of Planning, 2013, GIS data-inland water resources [Watersheds]: Hawaii Statewide GIS Program database, accessed August 8, 2013, at http://planning. hawaii.gov/gis/download-gis-data/.
Hawkins, R.A., 2011, A Pacific industry-the history of pineapple canning in Hawaii: London, New York, I.B.Tauris, $288 \mathrm{p}$.

Helsel, D.R., and Hirsch, R.M., 2002, Statistical methods in water resources: U.S. Geological Survey Techniques of Water-Resources Investigations, book 4, chap. A3, 510 p. [Also available at http://pubs.usgs.gov/twri/twri4a3/.]

Hirsch, R.M., 1982, A comparison of four streamflow record extension techniques: Water Resources Research, v. 18, no. 4, p. 1081-1088.

Hirsch, R.M., and Gilroy, E.J., 1984, Methods of fitting a straight line to data-examples in water resources: Water Resources Bulletin [renamed American Water Resources Association Journal], v. 20, no. 5, p. 705-711.

Kubota, G.T., 1999, Lahaina cane workers, lands face unpredictable future: Honolulu Star-Bulletin, September 3, 1999, accessed May 3, 2013, at http://archives.starbulletin. com/1999/09/03/news/story6.html.

Legates, D.R., and McCabe, G.J., Jr., 1999, Evaluating the use of "goodness-of-fit" measures in hydrologic and hydroclimatic model validation: Water Resources Research, v. 35, no. 1, p. 233-241.

Loaiciga, H.A., 1989, Variability of empirical flow quantiles: Journal of Hydraulic Engineering, v. 115, no. 1, p. 82-100.

Maui County Planning Department, 2012, Maui island plan-general plan 2030: County of Maui County Planning Department, Long Range Division web page, accessed May 7, 2013, at http://www.co.maui.hi.us/index. aspx? nid $=1503$.

Maui Land \& Pineapple Company, Inc., 2013, History: Maui Land \& Pineapple Company, Inc. web page, accessed May 2, 2013, at http://mauiland.com/history.shtml.

Oki, D.S., Wolff, R.H., and Perreault, J.A., 2006, Effects of surface-water diversion and ground-water withdrawal on streamflow and habitat, Punaluu Stream, Oahu, Hawaii: U.S. Geological Survey, Scientific Investigations Report 2006-5153, 104 p. [Also available at http://pubs.usgs.gov/ sir/2006/5153/.]

Oki, D.S., Wolff, R.H., and Perreault, J.A., 2010, Effects of surface-water diversion on streamflow, recharge, physical habitat, and temperature, Nā Wai 'Ehā, Maui, Hawai 'i: U.S. Geological Survey Scientific Investigations Report 2010-5011, 154 p. [Also available at http://pubs.usgs.gov/ sir/2010/5011/.]

PBR Hawaii, 2004, Maui island plan: Honolulu, PBR Hawaii, prepared for the State of Hawai'i Department of Hawaiian Home Lands, 340 p., accessed May 7, 2013, at http://dhhl. hawaii.gov/wp-content/uploads/2012/05/Island_Plan_ Maui_2004.pdf. 
Rantz, S.E., and others, 1982, Measurement and computation of streamflow: U.S. Geological Survey Water-Supply Paper 2175, 2 v., 631 p.

Ries, K.G., III, 1993, Estimation of low-flow duration discharges in Massachusetts: U.S. Geological Survey OpenFile Report 93-38, 59 p.

Ries, K.G., III, and Friesz, P.J., 2000, Methods for estimating low-flow statistics for Massachusetts streams: U.S. Geological Survey Water-Resources Investigations Report 00-4135, 81 p. [Also available at http://pubs.usgs.gov/wri/ wri004135/.]

Schroeder, T.A., 1993, Climate controls, in Sanderson, Marie, ed., Prevailing trade winds-weather and climate in Hawai 'i: Honolulu, University of Hawai'i Press, p. 12-36.

Searcy, J.K., 1959, Flow-duration curves, in Manual of Hydrology-Part 2. Low-flow techniques: U.S. Geological Survey Water-Supply Paper 1542-A, 33 p.

Smakhtin, V.U., 2001, Low flow hydrology—a review: Journal of Hydrology, v. 240, no. 3-4, p. 147-186.

Stearns, H.T., and Macdonald, G.A., 1942, Geology and ground-water resources of the island of Maui, Hawaii: Hawai'i Division of Hydrography Bulletin v. 7, 344 p.
Vogel, R.M., and Fennessey, N.M., 1995, Flow duration curves II-A review of applications in water resources planning: Water Resources Bulletin [renamed American Water Resources Association Journal], v. 31, no. 6, p. 1029-1039.

Vogel, R.M., and Stedinger, J.R., 1985, Minimum variance streamflow record augmentation procedures: Water Resources Research, v. 21, no. 5, p. 715-723.

Wilcox, Carol, 1996, Sugar water-Hawaii's plantation ditches: Honolulu, University of Hawaii Press, 191 p.

Yamanaga, George, and Huxel, C.J., 1969, Preliminary report on the water resources of the Lahaina District, Maui-State of Hawai 'i: Department of Land and Natural Resources, Division of Water and Land Development Circular C51, $47 \mathrm{p}$.

Yeung, C.W., and Fontaine, R.A., 2007, Natural and diverted low-flow duration discharges for streams affected by the Waiāhole ditch system, windward O`ahu, Hawai 'i: U.S. Geological Survey Scientific Investigations Report 2006-5285, 75 p. [Also available at http://pubs.usgs.gov/ sir/2006/5285/.]
For additional information regarding this publication, contact:

Director

Pacific Islands Water Science Center

U.S. Geological Survey

677 Ala Moana Blvd., Suite 415

Honolulu, HI 96813

email:dc_hi@usgs.gov

Or visit the USGS Pacific Islands Water

Science Center Web site at:

http://hi.water.usgs.gov

Prepared by:

Menlo Park Publishing Service Center, California

Edited by Larry B. Slack and Regan Austin

Design and layout by James E. Banton 
This page left intentionally blank 


\section{$\frac{1}{4}$}

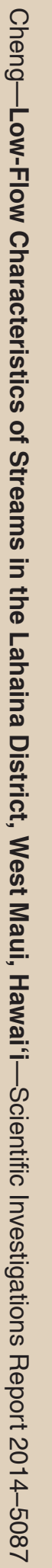

